\title{
The Eurasian steppe belt: Status quo, origin and evolutionary history
}

\author{
H. Hurka ${ }^{1}$, N. Friesen ${ }^{2,3}$, K.-G. Bernhardt ${ }^{4}$, B. Neuffer ${ }^{1}$, S. V. Smirnov ${ }^{5}$, A. I. Shmakov ${ }^{5}$, F. R. Blattner ${ }^{6}$ \\ ${ }^{1}$ Department of Botany, University of Osnabrueck, Barbarastrasse 11, 49076 Osnabrueck, Germany. \\ E-mail:herbert.hurka@osnanet.de, barbara.neuffer@biologie.uni-osnabrueck.de \\ ${ }^{2}$ Botanical Garden of the University of Osnabrueck, Albrechtstr. 29, 490776 Osnabrueck, Germany. \\ E-mail:friesen@biologie.uni-osnabrueck.de
}

${ }^{3}$ I. M. Sechenov First Moscow State Medical University Ministry of Health of the Russian Federation, Department of Pharmaceutical and Natural Sciences, Izmailovsky Boulevard, 8, Moscow, 105043, Russian Federation

${ }^{4}$ Institute of Botany, University of Natural Resources and Life Sciences, Vienna, Gregor-Mendel-Straße 33, 1180 Vienna, Austria. E-mail: karl-georg.bernhardt@boku.ac.at

\author{
${ }^{5}$ South-Siberian Botanical Garden, Altai State University, Lenina Str., 61, Barnaul, 656049 Russian Federation. \\ E-mail:serg_sm_@mail.ru; alex_shmakov@mail.ru \\ ${ }^{6}$ Leibniz Institute of Plant Genetics and Crop Plant Research (IPK), Corrensstrasse 3, 06466 Gatersleben, Germany. \\ E-mail: blattner@ipk-gatersleben.de
}

Keywords: Eurasia, landscapes, origin and evolution, paleoclimates, present state, steppes.

Summary. We present a comprehensive review of the characteristics and structure of the Eurasian steppe and of its evolutionary history in space and time. During the last decades, tremendous advances in research methods in earth and palaeontological sciences have greatly increased knowledge on palaeoclimates and palaeoenvironments of the Cenozoic era. We discuss well-known facts against the background of the recent progress made in these fields and others related to our topics, and address open questions.

In Part I (Status quo), we deal with steppe classification systems, human impact and present state of the Eurasian steppe. Here, we concentrate on prehistoric times when the first human cultures emerged, and on the last 100 to 200 years when drastic changes occurred and in many regions steppe nearly completely disappeared. In Part II (Origin and evolutionary history of the Eurasian steppe) we attend to the origin and evolution of grasses and grassland in general, and to the evolution and climate/landscape history of the Eurasian steppe belt in particular. Uplift of the Himalayan-Tibet Plateau, changes in land-sea distribution and global climate trends have been invoked as driving forces behind Cenozoic paleoclimate changes, but there is little consensus which one is the most important driver.

We finally identify gaps/challenges in our knowledge about the evolutionary history of the Eurasian steppe and discuss research directions, which might help to unravel the florogenetic and steppe habitat dynamics from the beginning of steppe formation to the present time.

\section{Евразийский степной пояс: статус-кво, происхождение и эволюция}

\author{
Г. Хурка ${ }^{1}$, Н. Фризен ${ }^{2,3}$, К.-Г. Бернхардт ${ }^{4}$, Б. Нойффер ${ }^{1}$, С. В. Смирнов ${ }^{5}$, \\ А. И. Шмаков ${ }^{5}$, Ф. Р. Блаттнер 6
}

\footnotetext{
${ }^{1}$ Кафедра ботаники, Университет Оснабрюк, Барбараштрассе, 11, Оснабрюк, 49076, Германия.

${ }^{2}$ Ботанический сад Оснабрюкского университета, Альбрехтитр. 29, Оснабрюк, 490776, Германия.

${ }^{3}$ Первый Московский государственный медииинский университет им. И. М. Сеченова, Министерство здравоохранения Российской Федерации, кафедра фармаиевтических и естественных наук, Измайловский бульвар, 8, Москва, 105043, Российская Федерация.
} 


\author{
${ }^{4}$ Институт ботаники, Университет природных ресурсов и естественных наук, Вена, \\ Грегор-Мендель-Штрассе, 33, Вена, 1180, Австрия. \\ ${ }^{5}$ Южно-Сибирский ботанический сад, Алтайский государственный университет, пр. Ленина, 61, \\ Барнаул, 656049, Российская Федерация.
}

${ }^{6}$ Институт генетики растений и исследований сельскохозяйственных растений им. Лейбница (ІРК), Корренсштрассе, 3, Гатерслебен, 06466, Германия

Ключевые слова: возникновение и эволюция, Евразия, ландшафты, современное состояние, палеоклиматы, степи.

Аннотация. В статье представлен всесторонний обзор характеристик и структуры евразийской степи и ее эволюции в пространстве и времени. В течение последних десятилетий огромный прогресс методов исследования в науках о Земле и палеонтологии значительно расширил знания о палеоклиматах и палеоокружении кайнозойской эры. Обсуждаются общеизвестные факты на фоне недавнего прогресса в этих и других областях, связанных с нашими темами, и решаем открытые вопросы.

В части I (Статус-кво) представлены системы классификации степей, влияние на них человека и современное состояние евразийской степи. Здесь наиболее подробно рассматриваются доисторические времена, когда возникли первые человеческие культуры, а также последние 100-200 годах, когда произошли радикальные изменения и во многих регионах степь почти полностью исчезла. В части II (Происхождение и эволюция Евразийской степи) рассматриваются происхождение и эволюция травянистых растений и лугов в целом, а также эволюция и история климата/ландшафта евразийского степного пояса в частности. Подъем Гималайско-Тибетского плато, изменения в распределении суши и моря и глобальные климатические тренды были вызваны изменениями кайнозойского палеоклимата, но нет единого мнения, какое из них является наиболее важным фактором.

И, наконец, в статье выявлены пробелы/проблемы в наших знаниях об эволюции евразийской степи и обсуждаются направления исследований, которые могут помочь распутать динамику флорогенетики и степных сообществ от начала формирования степи до настоящего времени.

\title{
Contents
}

1. Introduction 8

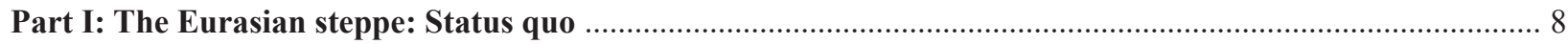

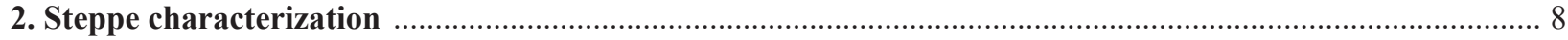

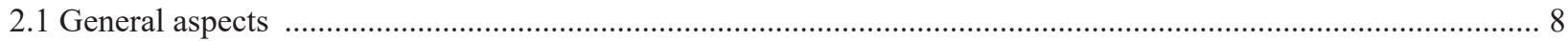

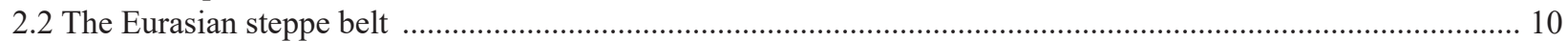

3. Steppe classification systems and latitudinal zonation of the Eurasian steppe region ................................... 10

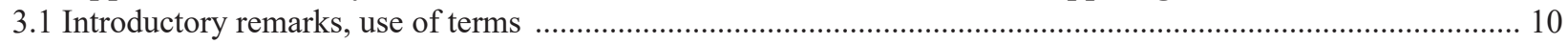

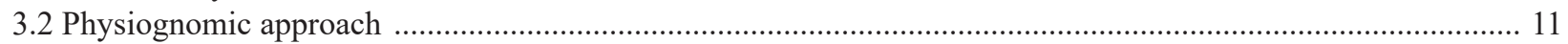

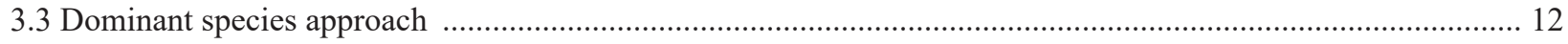

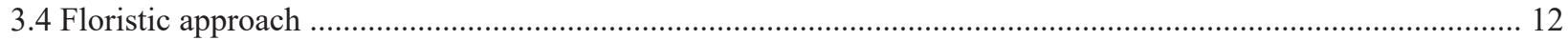

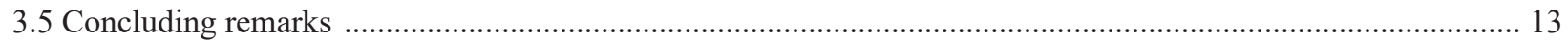

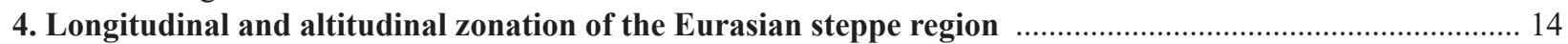

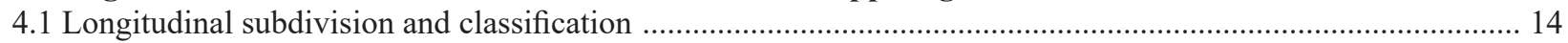

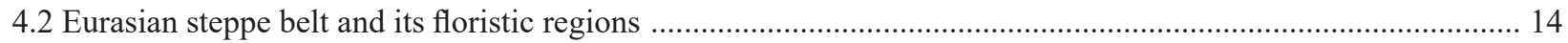

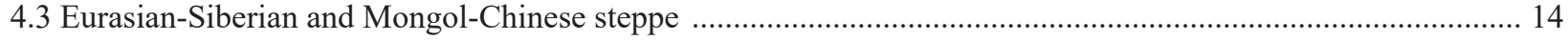

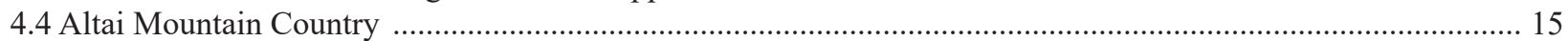

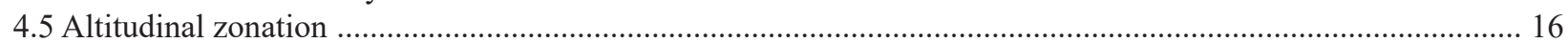

5. Human impact on Eurasian steppe formations and present state ......................................................... 16

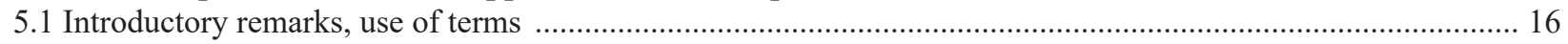

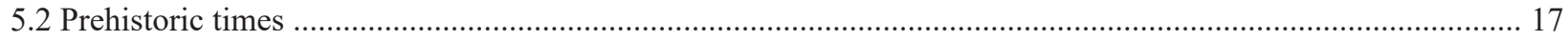

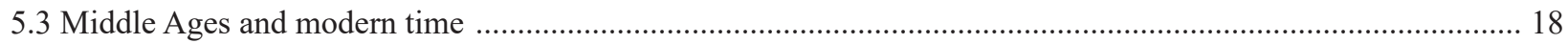

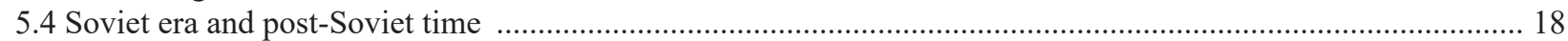

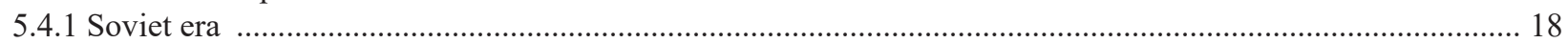

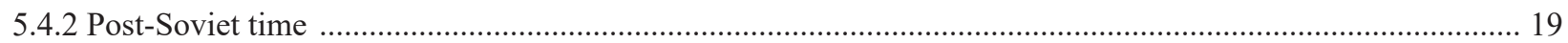

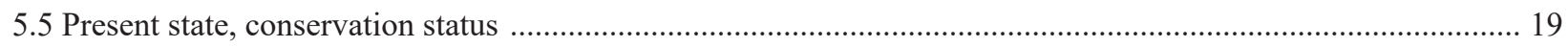

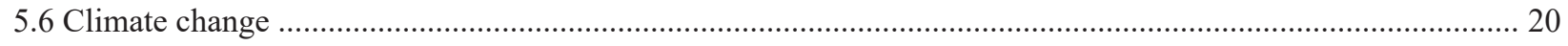




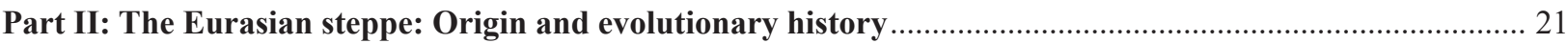

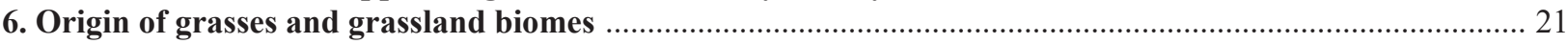

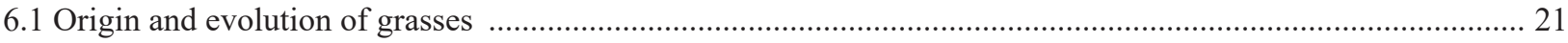

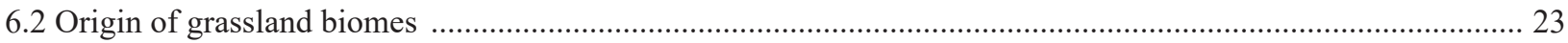

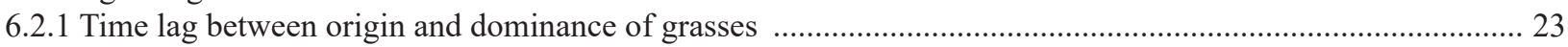

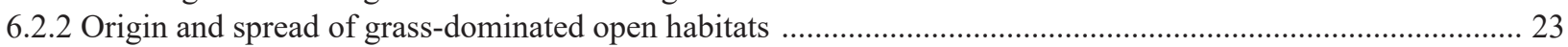

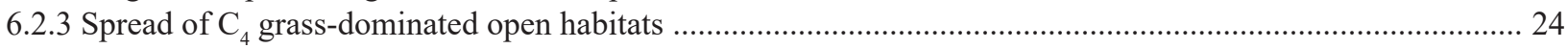

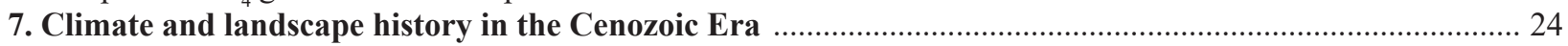

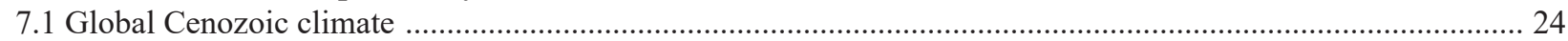

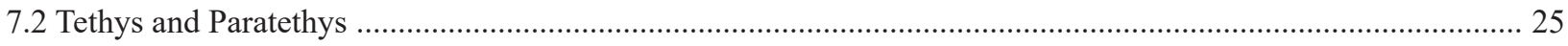

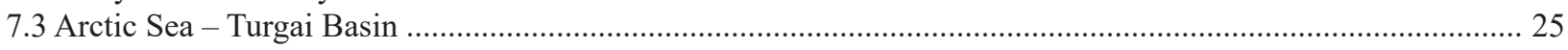

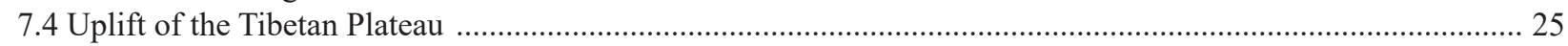

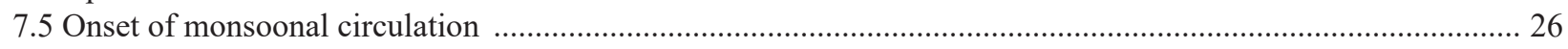

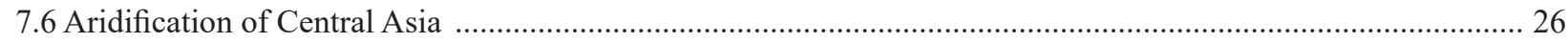

7.7 Paleogene vegetation in extratropical Eurasia (Palaeocene to Oligocene) ................................................. 27

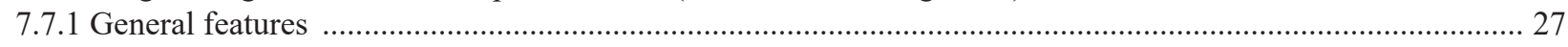

7.7.2 Synopsis of Paleogene climate and vegetation history in extratropical Eurasia ........................................... 28

7.8 Neogene vegetation in extratropical Eurasia (Miocene to Pliocene) ......................................................... 28

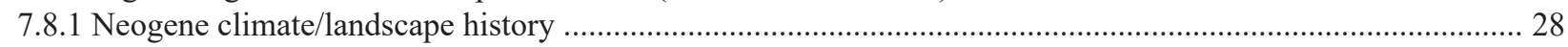

7.8.2 Synopsis of Neogene climate and vegetation history of the Mongol-Chinese steppe region .......................... 30

7.8.3 Synopsis of Neogene climate and vegetation history of the Euro-Siberian steppe region ...............................30

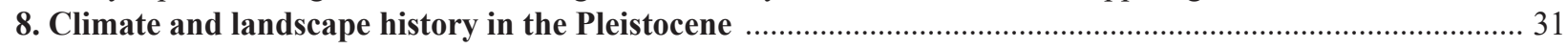

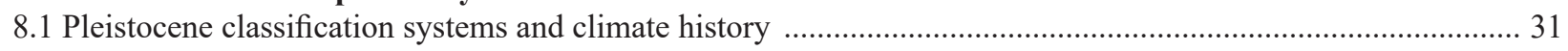

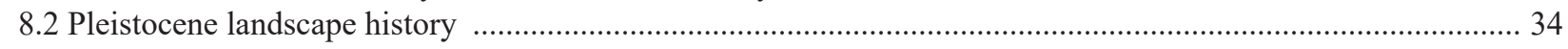

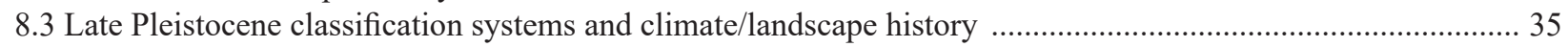

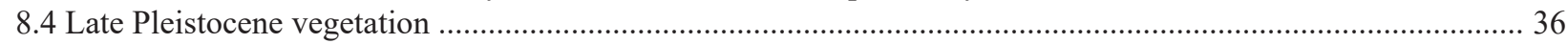

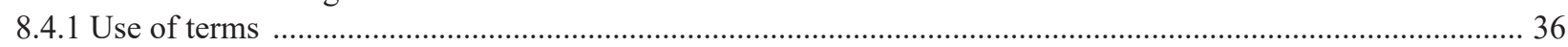

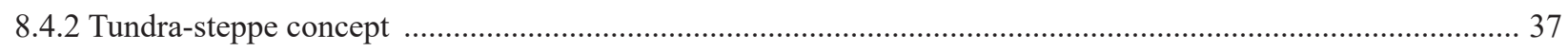

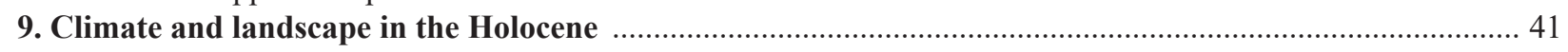

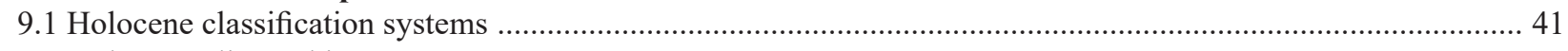

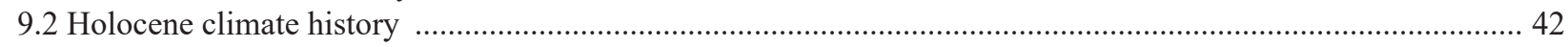

9.3 Megafaunal extinction at the Pleistocene - Holocene transition .............................................................. 42

9.3.1 Causes for the megafaunal extinction at the Pleistocene - Holocene transition .......................................... 42

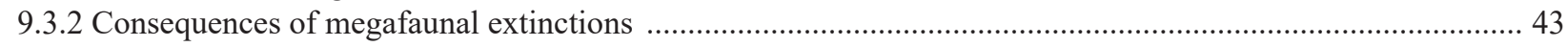

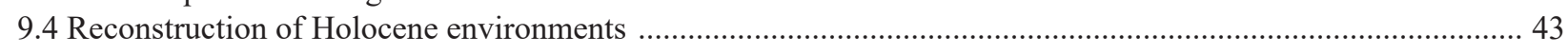

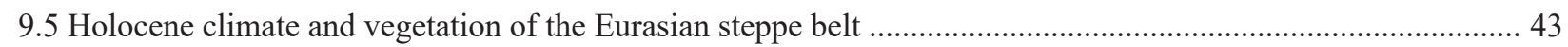

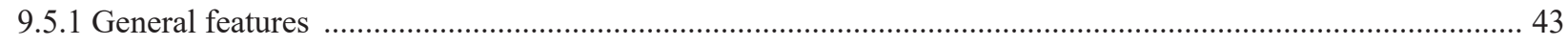

9.5.2 Holocene vegetation and climate histories of the Mongol - Chinese steppe region ..................................... 44

9.5.3 Synopsis of the Holocene climate and vegetation history of the Mongol-Chinese steppe region .................... 45

9.5.4 Holocene vegetation and climate histories of the Euro - Siberian steppe region ......................................... 45

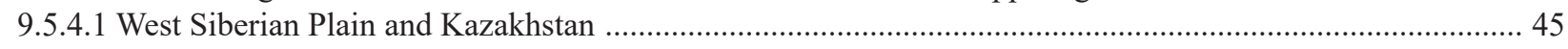

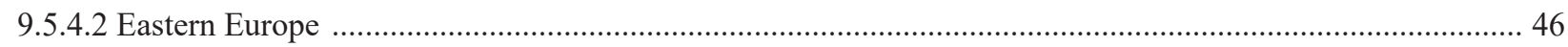

9.5.5 Synopsis of the Holocene climate and vegetation history of the Euro-Siberian steppe region ......................47

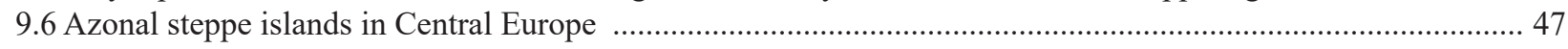

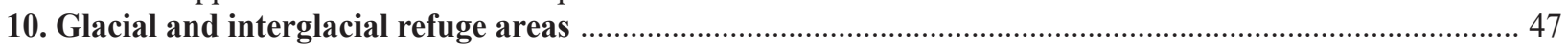

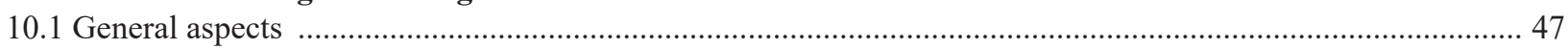

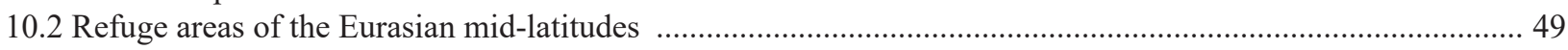

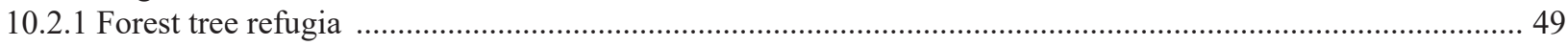

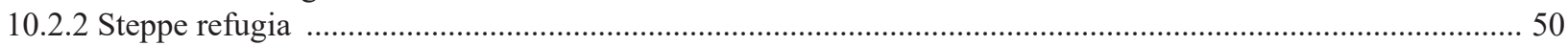

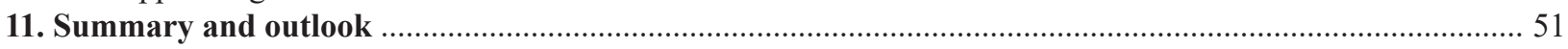

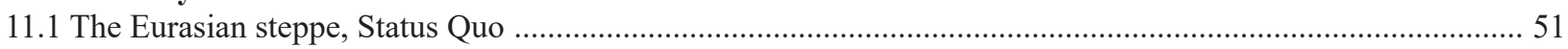

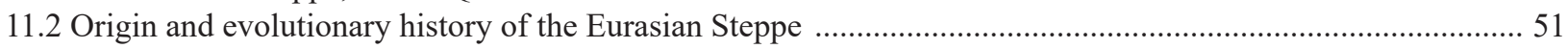

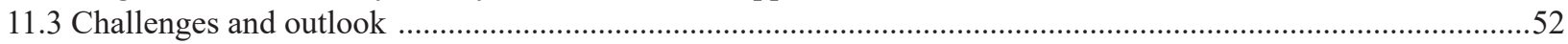

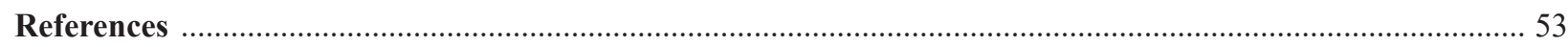




\section{Introduction}

Steppe is generally characterized as a grassland formation of the Earth's semiarid regions. The Eurasian steppe is the largest steppe region worldwide. In view of its ecological importance, studies on the evolutionary and biogeographical history of Eurasian steppe plants are largely missing. This contrasts conspicuously to other vegetation formations. Species histories of the large mountain system in Europe and North America and the circumpolar habitats of the Northern Hemisphere are in the focus of molecular phylogeographic studies but are generally rare for steppe plants. Some recent studies focus on genetic structure of central vs. marginal populations of certain steppe taxa and discuss possible explanations for the observed patterns including colonization histories (Wróblewska, 2008; Wagner et al., 2011; Durka et al., 2013; Hirsch et al., 2015). However, only few studies evaluate historical influences on contemporary genotypic patterns within a phylogeographical framework (Franzke et al., 2004; Hurka et al., 2012; Seregin et al., 2015; Friesen et al., 2016; Kajtoch et al. 2016; Meindl et al., 2016). Unfortunately, information on the climate/landscape history of the Eurasian steppe, its origin and evolution, is not only rather scattered throughout the literature but also often centred around the view and problems of a special scientific discipline (e.g., biogeography, biodiversity, climatology, palaeontology). The lack of an up-to-date comprehensive overall view of the evolutionary history of the Eurasian steppe belt makes it more difficult to test the congruence of species phylogenies and landscape evolution. Recent reviews on Eurasian grasslands, including steppes, focus either on regional scales like Central Europe (Poschlod et al., 2009; Hejcman et al., 2013) or primarily on biodiversity and phytosociological aspects (Dengler et al., 2014; Willner et al., 2016). Review articles on the origin of grasslands on a broader perspective are of older date (Jacobs et al., 1999; Bredenkamp et al., 2002), but recently Strömberg (2011) summarized the state of knowledge of the evolution of grasses and grassland ecosystems. Development of grassland ecosystems on most continents was a multistage process, and the timing of these events varied between regions. The latter reviews focus on the origin of grasslanddominated ecosystems on a worldwide perspective and seem to indicate a knowledge gap for the Eurasian steppe belt compared to other geographical regions. However, a great amount of Russian literature on the origin of the Eurasian steppe belt is available but not considered by Jacobs et al. (1999), Breden- kamp et al. (2002) and Strömberg (2011) as, for instance, the summary on climatic and environmental changes in Russia from the Palaeocene to the Holocene edited by Velichko and Nechaev (1999). This standard work has even been translated into English (Wright et al., 2005). The past decade has witnessed a rapid development of quantitative approaches for palaeoclimate reconstructions using fossil plants (e.g., Bruch et al., 2007; Utescher et al., 2011) and the interaction between palaeogeography, vegetation and climate is of special interest for the history of the steppe.

Advances in research methods, intensive field research over the last years and interdisciplinary as well as international cooperation have greatly increased knowledge on palaeoclimates and palaeoenvironments of the Cenozoic era. This is especially true for the Pleistocene landscapes of the Northern Hemisphere. Topics with particular relevance for the palaeogeographical history of the Eurasian steppe include (i) species migration, area dislocation, extension, contraction and reorganization of terrestrial biomes; (ii) interactions between herbivores and grassland and the impacts of megafaunal extinction, many of which were herbivores; (iii) steppe refuge centres during periods of unfavourable conditions. We will also address the present state of the Eurasian steppe, since it currently faces severe ecological problems and threats (Werger, van Staalduinen, 2012). Important issues in this context are (iv) the recent history (Holocene to present) of the Eurasian steppe; (v) human impacts on the steppe biome; and (vi) actual challenges and conservation actions.

The goal of our study is an up-to-date review of the characteristics, structure and composition of the Eurasian steppe, and of its historical development and dynamics in space and time. We will discuss well-known facts against the background of recent progress made in various disciplines related to this topic, and address open questions.

In Part I (Status quo), we deal with steppe classification systems in general as well as zonal patterns, human impact and present state of the Eurasian steppe. In Part II (Climate/landscape history), we attend to the origin and evolution of grasses and grasslands in general, and to the evolutionary history of the Eurasian steppe belt in particular.

\section{Part I: The Eurasian steppe: Status quo}

\section{Steppe characterization}

\subsection{General aspects}

To define the term 'grassland' turns out to be "a tautological problem" as Gibson (2009) put it ('a 
habitat dominated by grasses'). To find an all-encompassing definition of the term grassland is elusive. Main points that all definitions have in common are the dominance of grasses, infrequent or low abundance of woody vegetation, and a generally arid climate (Gibson, 2009). The world grasslands comprise the tundra as a treeless grass-dominated ecosystem beyond the temperature-related forest line, and the grass-dominated ecosystems in the semiarid and arid regions of the tropical, subtropical and temperate climatic zones. These regions are more or less treeless not because of temperature but of too low water supply to support tree growth. Climate in these latter grassland regions is seasonal with a dry and a wet season. Main precipitation is either in summer or winter times. The tropical and subtropical 'savannas' - a term, which obviously lacks conceptual clarity - exhibit an array of physiognomic forms between desert, grass savanna, dry woodland and dry forests. Similar to the savannas, the temperate grasslands - steppe, prairie and pampas - vary in physiognomy and species composition depending on variations in climate, soil, topography, and land use. (For detailed expositions see, e.g., Walter, 1962, 1968; chapters in Coupland, 1992, 1993; Gibson, 2009). Here, we concentrate on the steppes.

The term "steppe" is of ambiguous meaning. It was and sometimes still is applied to many treeless predominantly grassy vegetation formations caused by hygric and/or anthropogenic reasons. Allan (1946) named more than fifty diverse types of vegetation, which have been brought under the ample mantle of 'steppe', and he proposed that 'steppe' as an ecological term, "should be sent to rest in peace". Today, in vegetation science and plant geography, the term "steppe" has a much more narrow meaning to which we refer here (Walter, 1968, 1974). It characterizes a naturally treeless extra-tropical climatic vegetation formation dominated by droughtresistant xeromorphic grasses, perennial herbs and low shrubs as well as geophytes and therophytes. Steppe is the characteristic climax formation of the semiarid regions within the nemoral (= cool temperate) vegetation zones (Northern Hemisphere Eurasian steppe and prairie, and Southern Hemisphere pampas). However, the 'treeless steppe' may also depend on various kinds of physical disturbances like grazing and fire. Steppes are associated with semi-permanent areas of high atmospheric pressure systems and with great solar radiation characterized by a climate with cold winters, hot summers with a drought period, and summer rain (Walter, 1968, 1974; Ripley, 1992; Lavrenko, Karamysheva, 1993).
There are many attempts to fit the steppes into a global vegetation classification system. Well known are the systems based on zonal vegetation (climax vegetation) of Schmithüsen (1976) and many textbooks on plant geography like Schroeder (1998), the Zonobiomes of Walter (Walter, Box, 1976), the Ecozones of Schultz (Schultz, 2008), and the FAO Ecozones (FAO, 2001, 2012). They have in common that they are primarily based on climate parameters as temperature and rainfall and corresponding climate zones. Olson et al. (2001) on behalf of the WWF introduced a new global map of terrestrial ecoregions that are built on the foundations of classical biogeography. Within 14 major habitat types, which more or less correspond to climax vegetation formations, and eight biogeographic realms 867 ecoregions are categorized (for detailed description of the ecoregions see http://www.worldwildlife. org./biome-categories/terrestrial-ecoregions). The WWF Ecoregions are primarily intended as units for conservation action but also offer very valuable information for ecologists, systematists and biogeographers. Another classification system now frequently used by the European Union member states as a basis for designating conservation areas is EUNIS (European Nature Information System). It is a standardized habitat classification and integrates environmental factors with predominant vegetation. Eight habitats are classified at Level 1. The distinction between categories at Level 2 is based on the presence or absence of trees, climate zones, and soil moisture (http://eunis.eea.int/index.jsp).

In the system of Walter, steppes belong to the "Zonobiome VII" (Walter, Box, 1976; Walter, Breckle, 1999), i.e. the 'arid-temperate (continental)' zonobiome with the subzonobiomes semi-arid steppe, semi-desert and arid-desert. Forest-steppe is listed under the zono-ecotone VI/VII ('forest-steppe or grove-belt mosaic'). In the system of Schultz (2008) steppes are part of the "Dry Mid-Latitudes Ecozone", and in the FAO Ecozone System, steppes are listed under the "Temperate Domain" as the ecological zone 'Temperate steppes', and pro parte within the ecological zones 'Temperate deserts', 'Temperate continental forest' and 'Temperate mountain systems' (FAO codes TeBSk, TeBWk, TeM). Of relevance is also the "Subtropical Domain" with the ecological zone 'Subtropical steppes' (FAO code SBSh). In the WWF Ecoregions system, the Eurasian steppe belt belongs to the Palearctic realm within the 'Temperate grasslands, savannas and shrublands' habitat, and comprises 14 ecoregions including mountain steppes and forest-steppe (WWF 
codes PA0801 to PA0818, with four omissions). In the EUNIS classification, steppes belong to Level 1 habitat code E (grasslands and lands dominated by forbs, mosses or lichens), and are listed under Level 2 codes E1 (Dry grasslands) and E6 (Inland salt steppes) with several ecological units (habitats) each.

In the context of this review, we will not refer to these categories further, except where it appears appropriate. For our purpose, the steppe characterisation as outlined above is sufficient.

\subsection{The Eurasian Steppe}

It seems appropriate to refer to the terms 'Central Asia' and 'Middle Asia' first. The geographical area described by 'Central Asia' has been and still is differently used in the literature (Cowan, 2007). Often, 'Central Asia' refers to Asian areas of the former Soviet Union and to areas of Mongolia and China. This broad interpretation includes Kazakhstan, Turkmenistan, Uzbekistan, Tajikistan and Kirghizia. In the relevant Russian literature, these latter countries, however, are traditionally referred to as 'Middle Asia', and 'Central Asia' is confined to Mongolia, to large parts of northern China adjoining southern Mongolia, to the most eastern parts of Kazakhstan and to small parts of southwest Siberia adjoining northern Mongolia. This is approximately the area between longitude $80^{\circ}$ and $120^{\circ} \mathrm{E}$, and latitude $40^{\circ}$ to $50^{\circ} \mathrm{N}$, also referred to as 'Russian Central Asia'. In this review, we use the terms 'Middle Asia' and 'Central Asia' in the sense of the Russian biogeographical and geobotanical literature.

The largest steppe region in the world is the Eurasian steppe belt followed by the North American prairie. The Eurasian steppe stretches from the Hungarian basin and the Danube delta in the west to the Amur in the east, situated between $48^{\circ}$ and $57^{\circ}$ northern latitude, and between $27^{\circ}$ and $128^{\circ}$ eastern longitude. It ranges from 800 to $1000 \mathrm{~km}$ from North to South, and about $8000 \mathrm{~km}$ from East to West (Lavrenko, Karamysheva, 1993), and includes the world's largest dry steppe region from the Ural River in the West to the Altai foothills in the East, approximately along $48^{\circ}$ to $50^{\circ} \mathrm{N}$. To the North, the Eurasian steppe belt borders on deciduous forests in the West and boreal needle forest in the East; in the South, it borders on semi-deserts and deserts. Steppe exclaves occur in middle Europe and in northern Asia. The "prairie" of North America is the equivalent to the Eurasian steppe, thus prairie and steppe are synonyms. However, the Eurasian steppe spreads out along latitudinal gradients, whereas the
North American prairie along longitudinal gradients. It is interesting to note that in the North American steppes $\mathrm{C}_{4}$-grasses are common and partly dominating in the southern prairie whereas in the Eurasian steppes they are a minority as, e.g., the wideli distributed Bothriochloa ischaemum and Cleistogenes squarrosa. A few other $\mathrm{C}_{4}$-grass species from the genera Arundinella, Bothriochloa, Pennisetum and Themeda occur in the Chinese northern subtropical and tropical shrubby tussock grasslands ( $\mathrm{Hu}$, Zhang, 2003).

For the Eurasian steppe belt, an intense anticyclone causes the characteristic semi-permanent high atmospheric pressure system of the steppe regions. It develops over Mongolia during the winter and extends from Siberia and China into east Europe. The Mongolian anticyclone begins to disappear as continental temperatures rise in the spring and is gradually replaced by a depression by midsummer. Cyclonic activity is much more frequent over Central Asia during the summer (Ripley, 1992). Annual mean precipitation lies mostly within the 200-400 $\mathrm{mm}$ range. In the inner part of the Eurasian continent, increasing continentality towards the East favours the development of the steppe, whereas oceanic conditions to the West favours the development of forest.

\section{Steppe classification systems and latitudinal zonation}

\subsection{Introductory remarks, use of terms}

Extensive literature on vegetation classification has accumulated, with different approaches emphasizing different characteristics and often adopting different classification procedures. There is urgent need for common concepts and terminology to overcome this confusing and awkward situation as a consortium of experts point out in a recent article (De Cáceres et al., 2015). Steppe is no exception from this general situation. Classification and nomenclature of steppe formations is rather vague and far from being standardized and coherent. Three main classification approaches can be recognized, the physiognomic approach, the dominant species approach and the floristic approach. In the plant-geographical and geobotanical literature, a physiognomy-based division is traditionally preferred, whereas in vegetation science/ecology quite understandably the floristic composition is the leading guideline for division and nomenclature of the steppe formations. The dominant species approach, most successfully applied in Russia, is somehow in between. 
With regard to soil terminology, we use the traditional and familiar steppe-soil classification and nomenclature that is still mostly used in the steppe literature but we also refer to the corresponding soil groups of the World Reference Base for Soil Resources, WRB, in its latest/current version (FAO, 2015).

\subsection{Physiognomic approach}

Ellenberg and Mueller-Dombois (1967a, b) presented a physiognomic-ecological classification of plant formations of the earth, which is mirrored in many physiognomic steppe classification systems. We concentrate on three exemplary examples, which are widely used. They refer to zonal (latitudinal) vegetation types. Altitudinal zonality will be dealt with later.

Example 1 ("Long grass - Short grass steppe"): A strict physiognomic classification reflecting zonal climatic sequences along aridity gradients is the sequence forest-steppe - long (or tall) grass steppe mixed steppe - short grass steppe - desert steppe. (1) Forest-steppe characterizes the transition zone between steppe and closed forest, and grows on chernozems, Lessivé chernozems or phaeozems (WRB Reference Soil Groups: Chernozems, Luvisols and Phaozems; FAO, 2015). It is a macromosaic of meadow steppe and contrasting forest (or tree) islands. One should not confuse the term "forest-steppe" with "steppe forest", which means forests with undergrowth of steppe elements (Wendelberger, 1956; Walter, 1974). (2) Long-grass steppe (also referred to as wet steppe) develops as meadow steppe on black earth soils (typical and common chernozem, known as eu-chernozem), and as herb-rich feather grass steppe on carbonatchernozem (southern chernozem; WRB Reference Soil Group: Chernozems and their principal qualifiers; FAO, 2015). The transition zone between wet and dry steppes is sometimes named (3) mixed steppe and covers large areas in North America. (4) Short-grass steppe (also referred to as dry steppe) is typical for kastanozem soils (WRB Reference Soil Group: Kastanozems and their principal qualifiers; FAO, 2015) and appears as herb-poor dry feather grass steppe on weakly saline kastanozems, or as wormwood - feather grass steppe on strongly saline kastanozems. With increasing aridity, the kastanozem soils turn into burozems with semi-desert vegetation, and into serozems with desert vegetation (WRB Reference Soil Groups: Calcisols, Gypsisols, Arenosols, Regosols; FAO, 2015). (5) Desert steppe has only sparse grass cover and dwarf shrub and subshrubs prevail. The desert steppes are often assigned to the semi-deserts and deserts, and "true" steppes are then only the grass- and herb-rich steppe formations of the semi-arid regions, except for the forest-steppe.

Example 2 ("Stipa and Artemisia steppe"): Another primarily physiognomic steppe-classification system widely used in the European literature (following Kleopov, 1941 as outlined in Walter, 1968, 1974) is the differentiation between (1) Foreststeppe zone, a macro mosaic of meadow steppe and more or less sharply contrasting forest (or tree) islands (Walter, 1968). The meadow steppes comprise hygrophilous herb-rich variants, and, under less moist climates, the "typical" meadow steppe. Sometimes, the meadow steppes are treated as an independent category. (2) Feather grass steppes (Stipa steppes) constitute the true steppe-zone with herbrich variants on chernozems under moist conditions, and herb-poor variants on kastanozems under more dry conditions. (3) Wormwood (or sagebrush) steppes (Artemisia steppes) occur in the transition zone from feather grass steppes to semi-deserts on halophytic soils and comprise many variants with varying amounts of subshrubs and grasses, depending on aridity and salinity of soils.

Example 3 ("Bunch-grass steppe"): Russian geobotanists traditionally used still another terminology to characterize the zonal steppe types (Lavrenko et al., 1991; Lavrenko, Karamysheva, 1993). (1) Meadow steppes (= forest steppe) in semi-humid climates; (2) True or typical steppes classified into bunch-grass steppes (syn. tuft-grass steppes) with many forbs in semi-arid climates, and into bunchgrass steppes with few forbs in arid climates; (3) Desertified bunch-grass and dwarf half-shrubbunch-grass steppes (semi-desert steppe) in very arid climates; (4) Desert dwarf half-shrub-bunchgrass steppes in hypoarid climates.

The zonal vegetation pattern can be interrupted or replaced by interzonal and azonal steppe formations, which are often related to topography and edaphic properties, as for instance mountain steppe, valley steppe, sandy steppe, stony or petrophytic steppe, or halophyte communities. Saline soils develop on water-logged ground (solonchak, "white alkali" with halophytic vegetation) and on periodically wet ground (solonetz, strongly alkaline soils with natrophilous vegetation) (WRB Reference Soil Groups: Solonchaks and Solonetz; FAO, 2015).

An example of a recent application of a physiognomic approach is the Map of the Natural Vegetation of Europe, Scale 1:2.5 Mill. (Bohn et al., 2003). 
The classification system corresponds at the highest hierarchical level to the physiognomic-ecological system of Ellenberg and Mueller-Dombois (1967a, b). Fourteen zonal and extrazonal main plant formations (description $\mathrm{A}$ to $\mathrm{O}$ ), and five azonal main plant formations (description $\mathrm{P}$ to $\mathrm{U}$ ) are recognized. Formation L (Forest-steppe and dry grassland) and Formation M (Steppes) refer to steppe grasslands. At the second level, a subdivision is undertaken into (sub)zonal and geographical subgroups (Subformations) or into higher vegetation types with dominant species or characteristic species combinations in the main vegetation layer. The assignment of the vegetation types to ecological climate types follows the Zonobiome concept of Walter et al. (1975).

China after Australia and Russia has the third largest grassland areas in the world (White et al., 2000). Grassland and steppe classification in China differs slightly from the three examples given above. Nine grassland classes with varying numbers of subclasses and types are recognized. Steppe grasslands are listed in three classes. (a) Temperate Steppe Class with the three subclasses Temperate Meadow-Steppe, Temperate Typical Steppe and Temperate Desert-Steppe and 69 types. (b) Temperate Desert Class with the two subclasses Temperate Typical Desert and Temperate Desert Steppe and 39 types. (c) Alpine Steppe Class with the three subclasses Alpine Meadow Steppe, Alpine Typical Steppe and Alpine Desert Steppe and 17 types $(\mathrm{Hu}$, Zhang, 2003).

Looking closer, these three physiognomic exemplary classification systems have in common (and this applies also to other systems not referred to here as, e. g., Sochava, 1979) that they reflect decreasing humidity and changing soil parameters along a North to South gradient in Eurasia (East to West gradient in North America). They differ in terminology, in the breadth of their categories (meadow steppe, for instance, is mostly included in the forest-steppe zone but sometimes classified as a separate category), and in their reference to characteristic plant taxa. In this latter respect, they lead up to a floristic steppe classification system.

\subsection{Dominant species approach}

In the Russian geobotanical literature, a more taxon-based classification system of steppe communities is common, which refers to the dominant plant taxa of the major stratum but includes also physiognomic characteristics. The classification is hierarchical using syntaxonomic units, a terminology that partly coincides with those of the Braun-Blanquet system but differ in their contents (Alexandrova, 1973; Safronova, 2005). The lowest unit is the association. Associations with similar dominants and codominants are united into groups of associations, which with regard to their life forms are joined to classes. The classes are grouped into formations characterized by similar dominants in the dominant vegetation layer. To give some examples for steppe characterization: Stipa steppe, Cleistogenes steppe, Agropyrum cristatum steppe, Filifolium sibiricum steppe, etc. Often, the subdominant taxa are also named and are put before the dominant taxa, as e. g. Carex duriusculaStipa steppe, Artemisia frigida-CleistogenesStipa steppe, Stipa-Caragana steppe. Steppes without clear dominance of certain taxa are often referred to as "diverse steppe" as, for instance the classic polydominant 'four-grass-steppes' Festuca lenensis-Stipa krylovii-Cleistogenes squarrosaKoeleria cristata steppe (e.g., Lavrenko et al., 1991; Karamysheva, Khramtsov, 1995; Kamelin, 2005). As regards content, the association rank within the dominant species approach often corresponds to the association-rank of the Braun-Blanquet approach (see below).

The classification of desert and steppe vegetation on the European Vegetation Map follows the Russian dominant-determinant concept (Safranova, 2005) and corresponds to the Russian classification of arid vegetation outlined by Gribova et al. (1988).

\subsection{Floristic approach}

The floristic approach defines all vegetation types (called 'syntaxa') by their floristic composition. The traditional and best-known approach is the BraunBlanquet method. It aims at producing a universal classification system with four main hierarchical levels. These are in ascending ranking order: association, alliance, order and class. The Plant Sociological Code of Nomenclature (latest edition: Weber et al., 2000) rules the naming of the ranks. The Braun-Blanquet method is extensively applied in Europe but has followers worldwide.

With regard to the European steppe region ("Steppe Biome in the Temperate Grassland Biome"), Mucina (2013) identifies three classes: (i) Class Festuco-Brometea Br.-Bl. et R.Tx. 1943 with 11 orders and 49 alliances (typical for dry grassland and steppe vegetation of mostly base-rich soils of the submediterranen to the hemiboreal zones of Europe). (ii) Class Festucetea vaginatae Soó ex Vicherek 1972 with one order and six alliances (intrazonal vegetation in European continental steppes and 
dry grasslands on sandy soils). (iii) Class FestucoPuccinellietea Soó ex Vicherek 1973 with six orders and 29 alliances (intrazonal vegetation type in saline steppes and secondary steppic grasslands of the continental regions of eastern and southern Europe). The European "Continental semi-desert Biome" has one class Artemisietea lerchianae Golub 1994 with two orders and five alliances.

In central Asia, publishing on the vegetation according to the Braun-Blanquet system started in the 1970ies in Mongolia (Hilbig, 1995, 2006). In his book on "The Vegetation of Mongolia", Hilbig (1995) brought together extensive data on the vegetation of Mongolia, and he classified and ranked plant communities at the association ranklevel. Later, he published an annotated outline of the plant communities and added the higher ranks of the plant-sociological system: alliances, orders and classes (Hilbig, 2000). The steppe vegetation of Mongolia is classified into three classes: (i) Class Agropyretea cristati Hilbig et Korolyuk 2000 with two orders, three alliance and 14 associations (these plant communities occur in dry steppes and meadow steppes). (ii) Class Brometea korotkyi Hilbig et Korolyuk 2000 with one order, one alliance, one association and four plant communities not ranked (typical habitats are dune-sands). (iii) Class Stipetea glareosae-gobicae Hilbig 2000 with three orders, four alliances and 14 associations (these communities are typical for semi-desert and desert steppes with shrubs, half-shrubs, dwarf half-shrubs and low bunch grasses). Von Wehrden et al. (2009) present an updated inventory and classification of the plant communities of the Gobi region with some newly described communities at the association level.

Gadghiev et al. (2002) published a prodromus of a phytosociological classification after BraunBlanquet for the Central Asian steppe belt, covering Mongolia and adjacent Russian regions north of Mongolia as well as Chinese regions south and east of Mongolia. The authors recognize three classes each with orders, alliances and associations. (i) Class Ajanio-Cleistogenetea songoricae Mirkin et al. 1988 (syn. Stipetea glareosae-gobicae Hilbig 2000) with two orders, two alliances and nine associations. Compared to Hilbig (2000), the number of orders, alliances and associations is reduced. Some of the ranks correspond to Hilbig (2000), others are new. (ii) Class Cleistogenetea squarrosae Mirkin et al. ex Korolyuk 2002 (syn. Agropyretea cristati Hilbig et Korolyuk 2000) with four orders, seven alliances and 29 associations. From the four orders, only one corresponds to one of Hilbig's (2000) two orders. Two of the seven alliances correspond to two of Hilbig's (2000) three alliances, and 12 associations correspond to Hilbig's (2000) 14 associations. Gadghiev et al. (2002) reduce the class Brometea korotkyi from Hilbig (2000) to the association level. (iii) Class Festuco-Brometea Br.-B1. et R.Tx. 1943 is not referred to in Hilbig (2000) because, according to Gadghiev et al. (2002), these plant communities are confined to the mountain meadow steppes in the north-eastern Altai and western Sayan ridges outside Mongolia.

It is obvious, that compatibility between the Hilbig (2000) and Gadghiev et al. (2002) classification systems is limited although, for the most part, they cover identical geographic regions, use the same vegetation analyses methods and rely largely on the same stock of literature and relevés. This applies not only to nomenclature but also to the delimitation of the phytosociological ranks. Scientists not firmly familiar with phytosociological vegetation analyses, might be confused. In addition, the rather complicated taxonomy and phytosociological working procedures involved as well as the lack of a reliable and widely accepted standardization of the vegetation units, are not helpful to promote the use of the Braun-Blanquet method in steppe research as fruitful as this might possibly be. One should admit, however, that some of the problems are certainly due to the still limited floristic knowledge of these vast steppe regions. Our reserved attitude is in line with the critical comments of De Cáceres et al. (2015).

\subsection{Concluding remarks}

Summarizing this chapter on steppe classifications, we would like to stress that both classification systems - the physiognomic and the floristic systems - reflect environmental parameters like climatic gradients along latitude, longitude and altitude, edaphic factors, and anthropogenic influences like deforestation and grazing pressure as well as differences between floristic regions. Whereas a physiognomic classification may have its strength in comparing steppe formations on a broader, macro-geographic scale, a floristic classification is much more sensible to narrow-scale, micro-geographic changes, and can better take differences between floristic regions into account. In essence, both classification principles have their advantages and disadvantages, and none of them alone is sufficient to cope with the steppe conditions. It would appear that the dominant species approach is a practicable compromise for communication. 


\section{Longitudinal and altitudinal zonation of the Eurasian steppe region}

\subsection{Longitudinal subdivision and classifica- tion}

In view of the enormous longitudinal direction of the Eurasian steppe belt spanning ca. $8000 \mathrm{~km}$, climatic and floristic differences within the steppe belt are to be expected and may be expressed in a meridional zonation pattern. It was Lavrenko (1969, $1970 \mathrm{a}$, b) who proposed to divide the Eurasian steppe zone into two meridional subregions, the Black Sea-Kazakhstan subregion and the Central Asian (Dauro-Mongolian) subregion. Each subregion consists of five provinces.

A) Black Sea-Kazakhstan steppe Subregion:

A1) Eastern European Block with BalkanoMesian forest-steppe province, East European forest-steppe province, and Black Sea (Pontic) steppe province;

A2) West Siberian-Kazakhstan Block with West Siberian forest-steppe province and Transvolga-Kazakhstan steppe province.

B) Central Asian steppe Subregion:

B1) Dauro-Mongolian Block with HangayDaurian mountain forest-steppe province, Mongolian steppe province, and North Gobi desert-steppe province;

B2) Manchuro-North-western Chinese Block with Manchurian forest-steppe province, ShanxiGansuian forest-steppe and steppe province.

Different from Lavrenko is the division of Sochava (1979). He proposed a subdivision into three meridional sectors: European sector, VolgaSiberian-Kazakhstan sector, and Chino-Mongolian sector. This applies to his 'Forb-grass and forb steppes' (forest-steppe and northern steppe provinces) and to the "Tuft-grass steppes'. His third steppe type, the 'Sagebrush-grass steppes' (semi-deserts) is distributed from the Black Sea to the foothills of the Altai Mountains and thus borders in the North to the European sector and to the Volga-SiberianKazakhstan sector. Each sector has many associations as defined by the Russian dominant species approach (see above). Regarding content the division of Sochava is not far away from Lavrenko, it differs mainly in nomenclature and ranking orders. The division of Lavrenko, however, is mostly followed in the literature, and is adopted here by us.

\subsection{Eurasian steppe belt and its floristic re- gions}

It is the aim of phytogeography to delimit areas with floristic inventory as uniform as possible.
Boundaries of plant distributions, floral contrast and floral gradients are basic tools to divide the Earth's flora into kingdoms, regions and provinces. The Eurasian steppe belt belongs to the Holarctic Plant Kingdom (Holarctis), but several floristic regions have part in its floristic composition. Since the subdivisions of the Holarctis into Floristic Regions in general and with regard to the steppe in particular, is rather diverse and varying from author to author, we shortly comment on the different phytogeographical treatments. The western part of the Eurasian steppe belt is assigned by Meusel et al. (1965) to the Pontic-Southern Siberian Floristic Region extending to the North and West into the Middle European Region (especially Sarmatic and Central European Provinces), and to the South into the Macaronesian-Mediterranean Floristic Region (e. g. Macedonian-Thracian Province). The eastern part of the Eurasian steppe belt is put to the Central Siberian-Mongolian-Daurian Floristic Region with isolated steppe islands in the Circum Arctic and the Circum Boreal Regions. The eastern steppe belt has contact zones with the Oriental-Turanic Region and the Central Asiatic Region in the South, and borders the Sino-Japanic Region in the East (Northwestern Chinese-West Mandshurian Subregion).

The floristic divisions of Meusel et al. (1965) are more or less shared by Lavrenko (1969), by Kleopov (1941; cited in Walter, 1974), by Schmithüsen (1968), and by Walter (1974). Takhtajan (1986) and Schroeder (1998) present different classifications. Takhtajan (1986) assigned most parts of the Eurasian steppe belt to his Boreal Subkingdom of the Holarctis, namely the Circumboreal and the Eastern Asiatic Region, whereas the Mongolian Province with its steppe, semi-deserts and deserts belong to the Irano-Turanian Floristic Region of the Tethyan (Ancient Mediterranean) Subkingdom. Lavrenko (1969), however, considered the steppe and foreststeppe areas as a special region and assigned this region as a whole to a Mediterranean (Ancient Mediterranean) subdominion of the Holarctic dominion.

In Schroeder's system (1998), the Eurasian steppe region is subdivided into the Eurosiberian Subregion (belonging to his Southeurosiberian Floristic Region), and the Mongolian-Chinese Subregion (belonging to the Irano-Turanian Floristic Region).

\subsection{Euro-Siberian and Mongol-Chinese}

\section{Steppe \\ For clarity in use of terms and to avoid confusion} with floristic terminology outlined above, following on the whole Lavrenko (1969) and Schroeder (1998) 
we use the geographical terms Euro-Siberian Steppe for the western part of the Eurasian steppe belt, and Mongol-Chinese Steppe for the eastern part. The border between the Euro-Siberian Steppe and the Mongol-Chinese Steppe approximately runs along the line Yenisei River - Russian Altai - Mongolian Altai along the upper reaches of the Irtysh River. The Euro-Siberian and Mongol-Chinese Steppe regions differ in many respects.

Floristic composition - Floristic aspects clearly mirror the subdivision of the steppe belt into a western and eastern region. The distribution area of many plant taxa is restricted to only one steppe region. To quote just some examples: Completely or nearly completely restricted to the Euro-Siberian steppe are species of the genera Crambe (Brassicaceae), Ornithogalum (Liliaceae), Salvia (Lamiaceae), Seseli (Apiaceae), Trinia (Apiaceae), Tulipa (Liliaceae), and Verbascum (Scrophulariaceae). Examples for the Mongol-Chinese steppe are Cymbaria (Scrophulariaceae), Filifolium (Asteraceae), Hemerocallis (Liliaceae), Lespedeza (Fabaceae), Panzeria (Lamiaceae), Saposhnikovia (Apiaceae), Schizonepeta (Lamiaceae), and Stellera (Thymeleaceae). Although the grass genus Stipa occurs in both regions, dominant Stipa species in the Euro-Siberian steppe are, e.g., S. lessingiana, S. pennata and S. orientalis, while in the Mongol-Chinese steppe, e.g., $S$. baicalensis, $S$. krylovii and S. glareosa dominate. Some Stipa species occur in both steppe regions as for instance $S$. capillata. There are many species and species groups which do not only bridge the boundary between the two steppe regions but even span the whole Eurasian steppe belt as, for instance, the Agropyron cristatum (Poaceae), Allium strictum (Alliaceae) and Scorzonera austriaca (Asteraceae) species groups, Anemone silvestris (Ranunculaceae), Krascheninnikovia ceratoides (Chenopodiaceae), Sisymbrium polymorphum (Brassicaceae), and Veronica spicata (Plantaginaceae). For more examples see, for instance, Walter (1974), Lavrenko et al. (1991), Malyshev et al. (1999), Malyshev (2000) and Peshkova (2001). Distribution maps are provided in Meusel et al. (1965, 1978), Meusel and Jäger (1992) and the relevant floristic literature and floras.

Climatic factors - The main differentiating climatic factor is the time of annual rainfall. Maximum precipitation in the Euro-Siberian steppe is in early summer (May to June), whereas in the MongolChinese steppe it is in midsummer (July to August) due to the influence of the eastern Asiatic monsoon. July and August are the main growing season. The Altai Mountains are a western barrier for the eastern
Asiatic summer cyclones and deep pressure systems (monsoon rains). The Dauro-Mongolian region (Central Asia) of the Mongol-Chinese Steppe has an extreme continental climate, which is also reflected in extension of permafrost southwards into Mongolia (Lavrenko, Karamysheva, 1993; Sharkhuu, Sharkhuu, 2012). The forest-steppe zone of northeastern China (Manchuria), however, is influenced by the Pacific monsoon.

Edaphic factors - As outlined above, chernozems are the typical zonal soils for the long grass steppe ('wet steppe') in flat to undulating plains. Since the parent material of chernozems are mostly but not exclusively aeolian sediments (loess), the occurrence of chernozems often coincides with loess areas. Kastanozems (chestnut soils) are the typical soils of the short grass steppe ('dry steppe') south of the Eurasian long grass steppe belt. Parent material is a wide range of unconsolidated soils, and a large part of kastanozems has developed in loess (FAO, 2015). The "classic" zonal sequence of the steppe formations from North to South along decreasing humidity and increasing aridity gradients (foreststeppe - long grass steppe on chernozems - short grass steppe on kastanozems - semi-desert steppe desert steppe) is typical for the European part of the Euro-Siberian steppe. The more or less continuous forest-steppe and black earth steppe belt reaches the $\mathrm{Ob}$, and - interrupted by mountain steppe - the Yenisei. Further east of the Yenisei, prevailing soil types are leptosols in montane areas, kastanozems, burozems and serozems. Chernozem soils are rare and only locally found except for the most eastern part of Mongolia and northeastern China (FAOUnesco, 1971-1981; Gadghiev et al., 2002). In the Mongol-Chinese steppe, short grass dry steppe and Central Asian bunch-grass dry steppe prevail over large areas. Forest-steppe and black earth steppe are found in considerable area only in eastern Mongolia and in northeastern China (Schmithüsen, 1976; Atlas of the USSR, 1986).

Thus, the Euro-Siberian and the Mongol-Chinese steppes differ in floristic, climatic and in edaphic respects. They probably differ also in their evolutionary and biogeographic history (see below).

\subsection{Altai Mountain Country}

The Altai Mountain Country (AMC) and adjacent Tuva are the contact zone between the EuroSiberian and the Mongol-Chinese steppe, and probably were important refuge centres during the Pleistocene (Kamelin, 2005; Pyak et al., 2008). The AMC as defined in the new Flora of Altai (Kamelin, 2005) 
includes the Russian, Kazakh, Chinese and Mongolian Altai, the mountains bordering Dzungaria, the mountains of southwestern Tuva, and the main parts of the western Sayan ridges. In the far South, the Baitak Bogdo and the Adzh Bogdo ranges form the boundary of the AMC. Environmental differences between the areas of the AMC are tremendous and thus are biome types. From North to South, the AMC is embedded within the zonal vegetation types (biomes) of taiga (boreal forest), forest-steppe, steppe, semi-desert and desert. Zonal and altitudinal taiga prevail in the northeast and forest-steppe in the Northwest, whereas steppe, semi-desert and desert are characteristic for the eastern and southern parts. The flora of the AMC is very heterogeneous, too. It comprises species of diverse floristic regions of different biogeographic origin (Kamelin, 2005; Pyak et al., 2008).

\subsection{Altitudinal zonation}

High mountain systems within the Eurasian steppe belt occur in the eastern part of the steppe belt (Altai, Sayan, Hangay, Hentiy-Daurian Mountains). Vegetation belts in the mountains are generally determined by vertical gradients in climatic conditions, but the vegetation type also depends on landform, water availability, soil characteristics, exposition, etc. The term "mountain steppe", often referred to, is not suitable to classify altitudinal steppe zonation. Mountain steppe means a steppe formation, which is peculiar to almost all altitudinal belts, especially in Altai Mountains. Mountain steppes in the AMC occupy diverse habitats and represent very heterogeneous vegetation types: shrub steppe, short grass dry steppe, central Asian bunchgrass dry steppe, desert-like and desert steppe, sandy steppes and stony (petrophytic) steppes (Kamelin, 2005). These steppe formations can also occur in the plains. However, there are some steppe formations, which are not found in the plains as, for instance, the cold cryophytic steppes.

With regard to the steppe, there is no simple scheme for the altitudinal zonation available. Altitudinal zonation of steppe in the AMC is an excellent example to demonstrate its dependency on various parameters. As outlined above, different parts of the AMC belong to different floristic regions and steppe provinces. Major phytogeographical boundaries cross the Altai, and there are also climatic and edaphic differences in latitudinal as well as longitudinal zonation (see above). Kamelin (1998) proposed a first altitudinal zonation scheme for the entire AMC. Steppe complexes including the cryo- phytic steppe and semi-deserts are typical for the dry southern and eastern parts of the AMC throughout the whole altitudinal range. Small forest stands (often Larix) are confined to northern slopes, groves and along watercourses. In the more wet northern and western parts taiga complexes, pine forests and forest-steppe prevail. There, steppes are confined to the southern slopes.

\section{Human impact on Eurasian steppe formations and present state}

We will mainly concentrate on two periods, on prehistoric times when the first human cultures emerged in the steppes, and on the last ca. 100 to 200 years when drastic changes occurred and in many regions steppe nearly completely disappeared.

\subsection{Introductory remarks, use of terms}

When dealing with human impacts on steppe formations, one is confronted with terms like 'primary' and 'secondary' grassland, 'natural' and 'semi-natural' grasslands, 'permanent', 'anthropogenic' and 'man-made' grasslands. Unfortunately, these terms are not standardized. Authors use the terms differently, sometimes even differently by the same author. 'Natural grasslands' are subject to little or no deliberate direct modification by humans in contrast to grasslands, which are subjected to various degrees of intensive management (Gibson, 2009). Since large grazing mammals are an integral part of the steppe ecosystem, be it wild game or domestic livestock, the transition between 'natural' and 'nonnatural' steppe grasslands is fluid. Natural grasslands are sometimes termed 'primary' grasslands (Bredenkamp et al., 2002). But the term 'secondary grasslands' is not consistently used to describe 'non-natural' grasslands, as, e.g., Bredenkamp et al. (2002) do when they use 'anthropogenic' or 'man-made' grasslands as synonyms for secondary grasslands. Steppe grassland, which has emerged through long time low-intensity human land use, is termed 'semi-natural', and grassland mown for hay is a meadow and one used for grazing is a pasture (Gibson, 2009; Dengler et al., 2014). In addition, the term 'semi-natural' grassland is restricted to those steppe formations, which have developed from forests as potential vegetation (Gibson, 2009; Dengler et al., 2014). Sometimes, 'semi-natural' grassland is used as synonym to 'secondary' grassland (Dengler et al., 2014), and sometimes secondary grassland (also termed 'permanent' grassland by Gibson, 2009) is a subcategory of the semi-natural 
grasslands (Gibson, 2009). The term 'semi-natural' grassland as defined by low-intensity human land use and emerging from forests as potential natural vegetation might make sense for Europe, but large parts of the Eurasian steppe as a whole, especially in Central Asia, would not be 'semi-natural' despite developing from low-intensity human impact since they did not originate from forests. In the light of these terminological confusions, we will avoid these terms when discussing human impact on steppe formations, or comment on it if used.

Referring to dates, we use BP (years before present), the most commonly used convention in radiocarbon dating. 'Present' refers to the year 1950, when the calibration curves were established (in more recent literature, 'present' often refers to the year 2000). We also use the traditional date descriptions BC (before Christ) and AD (Anno Domini for after Christ) being aware of the recent recommendation to replace BC by BCE (Before Common Era) and $\mathrm{AD}$ by $\mathrm{CE}$ (Common Era).

In periodization of human history, we follow the Three-Aged System: Stone Age - Bronze Age - Iron Age. The Stone Age is subdivided into the Pleistocene Palaeolithicum and the Holocene Meso- and Neolithicum. The Mesolithic/Neolithic period starts at ca. 10,000 BC and ends with the rise of the Bronze Age, ca. 3500 BC. In the so-called ASPRO system, the Neolithicum begins with the start of farming and ends when metal tools became widespread in the Copper Age, Bronze Age or Iron Age, depending on the geographical region. It can be roughly dated from $9000 \mathrm{BC}$ to ca. $2000 \mathrm{BC}$ or even younger. The Three-Age System is nowadays commonly used in archaeological literature, and we refer to this chronology as given in Hanks (2010) for the Eurasian steppes.

The Iron Age is traditionally subdivided into the Prehistoric (or Proto-historic) and the Historic Iron Age, delimited from each other by the development of written language. Both sub-periods together constitute the 'Classic Iron Age'. It lasts from ca. 1300 $\mathrm{BC}$ to ca. $500 \mathrm{AD}$, the prehistoric sub-period from ca. $1300 \mathrm{BC}$ to ca. $300 \mathrm{BC}$, and the historic subperiod from ca. $300 \mathrm{BC}$ to ca. $500 \mathrm{AD}$. The end of the Classic Iron Age is the beginning of the Middle Ages. This terminology and time division, which we follow here, is not fully compatible with divisions in usage at regional scales. In Middle Europe, for instance, the term 'Iron Age' is more or less confined to the prehistoric Iron Age of the Three-Age System. In northern Middle Europe and Scandinavia, a 'Pre-Roman Iron Age' (ca. 700 BC to 1 BC) is followed by the 'Roman and Germanic Iron Ages' (1 AD to ca. $800 \mathrm{AD}$ ), and finally by the 'Viking Age' (ca. $800 \mathrm{AD}$ to $1100 \mathrm{AD}$ ), eventually termed 'Late Iron Age'. One has to take these different applications of the term 'Iron Age' into consideration to avoid misinterpretations of the time scales.

\subsection{Prehistoric times}

Early colonization by man across the vast northern Eurasian plains has been proved already for the upper Palaeolithic in the late Pleistocene, 46,00010,000 BP, including northeastern and eastern Siberia, the Russian Far East, southern Siberia and the east of European plain (Hanks, 2010 and literature cited therein; Pitulko et al., 2016). In the Mesolithic to Early Neolithic period (ca. 10,000-6000 BC), early Holocene hunter-forager societies have been proved for Europe and for the southern Siberian region (Parzinger, 2006; Hanks, 2010 and literature cited therein). A key development was the domestication of horse in the Neolithic - Eneolithic period (ca. 6000-3500 BC). Molecular studies point to multiple origins of modern horses (Warmuth et al., 2011; Achilli et al., 2012), but one origin of horse domestication was the Eurasian steppe, probably its western central region (Warmuth et al., 2012). Much later, camels were domesticated. During the Bronze Age (3500-1200 BC) the Eurasian steppe region saw large-scale patterns of movements and inter-regional trade. Key developments were the emergence of spoke-wheeled chariot technology, metal mining and metallurgy (Hanks, 2010 and literature cited therein), which did not only fuel inter-regional trade but also military conflicts and wars of conquest (Anthony, 2007). The prehistoric Iron Age (1200-300 $\mathrm{BC})$ was a period of strong social and technological change connected with territorial conflict and control. In the Euro-Siberian steppe, the whole period is characterised by kurgans, namely the Scythian tombs, which provided an image of the Eurasian steppe during the Iron Age (Parzinger, 2006, 2009; Hanks, 2010). Mobile pastoralism ('nomadic pastoralists') and mounted warfare (cavalry) increased tremendously, and fundamentally depended on horse and cattle breeding. Recent field research, however, provided also evidence for agriculture in the steppe and forest-steppe zones. Domesticated cereal production and agro-pastoral economic regimes have been proved for Kazakhstan (Miller Rosen et al., 2000), and southern Siberia (Murphy et al., 2013), and agriculture appears to have become well established in the western steppe during the Iron Age. In the Pontic steppe region, the Scythian 
farmers apparently grew wheat, barley, millet, beans and onions for their domestic use and exported great amounts of cereal crops to the Greece (Parzinger, 2009). Pollen diagrams from the forest-steppe zone in northwestern Romania corroborate the cultivation of cereals during the Iron Age (Feurdean et al., 2015).

The impact of the prehistoric cultures on the steppe ecosystems is generally regarded as low, except locally around sites of special interest such as settlements, water holes, mines of ores and salt, and agricultural land (see Preface in Werden, van Staalduinen, 2012). Nevertheless, it stands for discussion to what degree the climate borders of steppe, especially the forest-steppe region, were extended at that early times already by biotic factors such as human activities and herbivores, be they domestic or wild grazers. Biotic and climatic drivers as competing hypotheses are of particular relevance for the Holocene (Craine, McLauchlan, 2004).

The vegetation history of the Eurasian steppe region in prehistoric times is different from that of Central Europe. In Central Europe, the anthropogenic transformation of the early Holocene woodlands into a cultivated landscape started already ca. $6000-5000$ BC by opening of the forests and forest clearing (Pott, 1995; Kalis et al., 2003; Kuneš et al., 2008; Poschlod et al., 2009; Ellenberg, Leuschner, 2010; Hejcman et al., 2013; Poschlod, 2015). We will come back to this issue later when discussing possible Holocene refuge centres in Central Europe. In this context, we will also shortly deal with the 'Steppenheidetheorie' of Gradmann (1933).

\subsection{Middle Ages and modern times}

Historically, nomadic herders used nearly all Eurasian steppe regions extensively for sheep, horse, cattle, and camel breeding. During the Middle Ages and modern times steppe was increasingly used as pastureland, but it was also the beginning of ploughing up forest-steppe habitats for agriculture. Human activities transformed steppes and forest-steppes more than any other part of northern Eurasia. "It is fair to say, that with the exception of rather small protected areas, the biogeography of the European steppes and forest-steppes is now cultural rather than natural" (Chibilyov, 2002). The Hungarian Puszta, for instance, is largely an anthropogenic steppe replacing the natural forest-steppe (De Soó, 1929). In Hungary, most of the land suitable for agriculture had been ploughed already by the eleventh century, and the forest cover reached its minimum in the eighteenth century, when steppe woodlands had largely disappeared (Molnár et al., 2012). "Russian agriculture was born in the forest zone" as well (Levykin et al., 2012). In the seventeenth century, modern crop-based agricultural development started in Russia in the East European forest-steppe and meadow steppes zones and gradually extended to the East and South. In the eighteenth century, ploughing of steppe and intensified grazing began also in Ukraine, and at the end of the nineteenth century, large areas of steppes and hygric herb-rich bunch-grass steppes (tall grass steppe on chernozems) in Russia were turned into arable land for crop and fodder production. At the end of the nineteenth century, cropland reached the desert steppes near the Caspian Sea in European Russia (Smelansky, Tishkov, 2012).

\subsection{Soviet Era and post-Soviet time \\ 5.4.1 Soviet Era}

Grand-scale destruction of steppe ecosystems occurred in the Soviet era (1917 to 1990), when the official agrarian policy was dominated by the "transformism' approach in land use. These developments reached their zenith in the 'virgin lands campaign' of 1954 to 1963 . Big collective state-owned farms were created to expand food production, mainly wheat and barley, and livestock breeding was also intensified. Rivers and wetland were drained on a large scale, and roads and canals were constructed. The 'virgin lands campaign' transformed the face of the steppes and led to large-scale changes in society and ecology (Levykin et al., 2012). Nearly all plain black-earth and chestnut soil steppes in the former Soviet Union in the west of the Volga were ploughed up. Some steppes in the east of the Volga survived in larger areas, e.g., in the southern Ural and foothills of the Altai Mountains as well as in the west Siberian and Daurian plains. However, the conversion of the dry herb-poor bunch-grass steppe (short grass steppe on kastanozems) into arable land failed mainly due to climate fluctuations, aridity and widespread salinity. Inappropriate agricultural land use caused severe ecological damages. Vast areas were affected by desertification processes as deflation and soil salinization. Some of this new cropland had to be abandoned already at the end of the 1960s (Smelansky, Tishkov, 2012; see also Rachkovskaya, Bragina, 2012). Notorious example of desertification is the Kalmykian steppe (Zonn, 1995). The sensitive dry steppe ecosystems, traditionally used as pasture lands, were overexploited by excessive animal production, and fragile pastures were converted into cropland, which resulted "in the creation of 
Europe's first anthropogenic desert" (Saiko, 2001). Another infamous example is the desiccation of the Aral Sea due to mismanagement of irrigation during the so-called 'cotton independence' policy (Saiko, 2001).

Grassland was also strongly converted in China. About $90 \%$ of the grassland, including steppe ecosystems, is degraded due to long-term inappropriate human activities. With the explosive growth of human population mainly in the second half of the twentieth century, livestock numbers increased excessively leading to severe overgrazing. In addition, great parts of steppe land were ploughed and cultivated but inappropriately managed, e.g., by overharvesting and improper mowing (Cui et al., 2012). The degradation of the Chinese steppe ecosystems led to serious desertification, and China is worldwide one of the countries most affected by it (Dong et al., 2012). The most desertified steppe regions in China are the 'sandlands', shifting inland sand dunes.

The Soviet Union and Chinese governments explicitly aimed at ending nomadism in the steppe, the Mongolian communist government, however, supported pastoral nomads and improved infrastructure for them. Mongolia is the only Eurasian country where today substantial numbers of nomadic pastoralists still exist. However, during the last three decades, the total number of livestock has increased almost twice from 23 to ca. 45 million animals, and the herd structure changed: the number of goats increased 3-4 fold. This burgeoning animal load has disrupted the natural balance by overgrazing and promoted degradation and desertification (Hilbig, 1995; Bazha et al., 2012; Wesche, Treiber, 2012).

\subsubsection{Post-Soviet time}

The first decade after the collapse of the Soviet Union (from 1990 to 2000) was characterised by a breakdown of industry, infrastructure and social systems in post-Soviet countries. The transition from state-controlled to market-driven economies caused drastic socio-economic changes (Levykin et al., 2012). These changes had a great impact on landscapes and biodiversity in the steppe zone. Arable land over vast areas was abandoned, and a massive decline in livestock reduced grazing pressure on pastures. This led to a recovery and return of steppe vegetation in certain areas (Hölzel et al., 2002; Charles, 2010). However, rates of land-use change varied considerably within Russia and between the post-socialist countries (Prishchepov et al., 2013). Since about 2000, the trend towards land abandon- ment and decrease of livestock numbers reversed in many parts of the former Soviet Union. Crop production was again given priority by Russian authorities, and, with governmental support, re-ploughing of fallow lands in the steppe zones was intensified and expanded during the last decade (Levykin et al., 2012), which again threats steppe vegetation and steppe wild life (Kamp et al., 2011; Neronov et al., 2012).

The decline of agricultural production at the end of the Soviet era and beginning of the post-Soviet time led to a significant increase of steppe wildfires. Studies in the trans-Volga-Ural region revealed that improper management practices, which, among other consequences, led to accumulation of leaf litter, are the main reasons (Pavleychik, 2015, 2016). Similar conclusions about causes and dynamics of fire risk are also reached for other steppe regions of the Russian Federation (Pavleychik, 2017).

\subsection{Present state, conservation status}

Since thousands of years and especially today, the primary climax steppe biome is highly influenced, disturbed and transformed by human activities as, e. g., forest clearing, agriculture, and pastoralism. In many regions, natural steppe vegetation remains only in nature reserves, in gullies and ravines, on the slope of river valleys, on the edges of fields, and along roadsides. Main destructive threats for the steppe biome are conversion of steppe into cropland, overgrazing, mining, oil and gas development, urban encroachment and afforestation. The magnitude of these threats varies between regions. The worst threat in Russia, for instance, is conversion into agricultural land, but in Mongolia, it is overgrazing and expanding mines and oil fields.

When talking about protected areas one has to bear in mind that protected area types are often different between countries, which makes it more difficult to draw comparisons between countries. Furthermore, the IUCN has developed a protected area management categories system. However, the classification systems of single countries are often distinct from that of the IUCN.

Temperate grasslands, savannas and shrublands are the least protected biomes worldwide with only $5 \%$ of their total area being conserved (Brooks et al., 2004). In addition, protected areas are often biased towards places that are unlikely to face land conversion pressures even in the absence of protection, as being situated on steep slopes, at higher elevations, and with greater distances to roads and cities (Joppa, Pfaff, 2009). They are biased also towards locations 
that are cheap to protect and distant from important areas of biodiversity (Venter et al., 2014).

Conservation status of the Eurasian steppes follows these trends. In all post-Soviet countries, protected areas (nature areas of preferential protection) in the steppe zone do not concentrate on typical, zonal steppe ecosystems and landscapes but mainly cover intrazonal locations restricted to special habitats as, e.g., saline or rocky or sandy places (Levykin et al., 2012).

In Russia, most of the steppe biome remains unprotected. Only $0.1 \%$ of the steppe biome area is formally conserved, which is the lowest value of protected area coverage among all biomes of Russia (Smelansky, Tishkov, 2012). The situation is similar for Europe with only ca. $0.2 \%$ of temperate grassland being protected (Knapp, 2005; for Ukraine see Korotchenko, Peregrym, 2012; Moysiyenko et al., 2014). Protection level of steppe ecosystem types (meadow steppe, dry steppe, semi-desert steppe and desertified steppe, excluding forest-steppe) for Kazakhstan averaged prior to 2009 about $1.5 \%$. The target for 2010 was to protect $1.9 \%$ of the steppe zone, and $2.2 \%$ by 2013 (United Nations Development Program UNDP/Global Environmental Facility GEF project, contracting authority: Government of Kazakhstan, project scheduled for the period 2009-2014; see also Rachkovskaya, Bragina, 2012). In Mongolia, less than $6 \%$ of the steppe region has protected status and only $2 \%$ of that is adequately managed and enforced (The Nature Conservancy, internet accessed 29.3.2016). Protected areas in China known as Nature Reserves (NR) are divided into several categories, the National Nature Reserves (NNR) being the strictest. NNR protected areas in East China, where most of the steppe and meadow steppe ecosystems are located, are only $4.75 \%$ (Inner Mongolia $2.9 \%$ ). Less than $2 \%$ of the total NR area is covered by steppe and meadow steppe, and only $0.76 \%$ of the total NNR area comprises steppe and meadow steppe ecosystems (Cui et al., 2012; Guo, Cui, 2015). By the end of the last century, the Daurian steppe in Mongolia, Russia and China had still ca. $72 \%$ remaining in grassland and is the largest remaining grassland in the Eurasian steppe biome and the second largest worldwide (White et al., 2000). Here, as part of the WWF 'Global 200' initiative, a model for transboundary conservation was founded in 1994, the Chinese-Mongolian-Russian 'Dauria International Protected Area (DIPA)'. However, there is still urgent need for transboundary cooperative strategies for grassland restoration and conservation, especially regarding habitat conserva- tion for migrating wildlife such as the Mongolian gazelle (Kirilyuk, 2014).

Palaearctic steppes including the Eurasian steppe belt have become one of the most endangered terrestrial biomes of the world. A special issue of the journal "Biodiversity and Conservation" (vol. 25, issue $12,2016)$ deals with the ecology, biodiversity and conservation of Palaearctic steppes (for definition of the Palaearctic steppe biome see Wesche et al., 2016). It comprises research papers from different regions throughout the biome, giving an overview of current knowledge and knowledge gaps (see Editorial by Török et al., 2016).

A coherent European ecological network of special areas of conservation was set up in 1992 under the title 'Natura 2000 ' to "maintain and restore, at favourable conservation status, natural habitats and species of wild fauna and flora of Community interests" (Council of the European Communities, Council Directive 92/43/EEC of 21 May 1992 on the conservation of natural habitats and of wild fauna and flora). Annex I of the Council Directive 92/43/ EEC (the so called "Habitats" Directive) lists the habitat types whose conservation requires designation of special areas of conservation. Habitat types in danger of disappearance and whose natural range mainly falls within the territory of the European Union are termed priority habitat types. Annex I from 1992 has been updated several times to incorporate habitats occurring in new EU Member States and to correct some errors or add newly acquired information. The latest version EUR28 is from 2013 (European Commission, Scientific reference document, Interpretation Manual of European Union Habitats EUR28, April 2013). Following priority habitat types with regard to steppe biomes are listed in the EUR28 version: xeric sand calcareous grasslands; semi-natural dry grasslands and scrubland facies on calcareous substrates (class Festuco-Brometalia) as far as they include important orchid sites; Subpannonic steppic grasslands; Pannonic loess steppic grasslands; Pannonic sand steppes; Ponto-Sarmatic steppes; Pannonic salt steppes and salt marshes. The "Habitats Directive" is a European Union legislative instrument in the field of nature conservation.

\subsection{Climate change}

On top of all these threats and conservation efforts come the effects of climate change, which seem to be particular obvious already in the northern zone of the Eurasian steppe biome, Mongolia serving as a concrete example. 
The impact of climate change is profound in Mongolia. Annual temperature increased by 2.14 ${ }^{\circ} \mathrm{C}$ in the past 70 years and has intensified in the last ten years, thus warming rates clearly outrange the global average (Sanjmyatav, 2012; Menzel et al., 2016). Annual number of cold days decreased, and the number of hot summer days increased. Precipitation in winter increased and has an effect on snow cover. Snow cover is very sensitive to changes in temperature and experienced the most significant seasonal and inter-annual changes in the whole Northern Hemisphere (Kong, Wang, 2017, and literature cited therein). In Mongolia, extreme winters (high snow cover preventing access to forage on winter pastures) were more frequent since the year 2000. In contrast to winter precipitation, precipitation in summer decreased, which leads to more draughts and water resources drying up. About $75 \%$ of pastureland is affected by medium to intense desertification. The frequency of forest and steppe fires increased because of the drought, and the length of the season of fire risk also increased (Sanjmyatav, 2012, and literature cited therein). Climate cycles in the Daurian ecoregion (alteration of dry and wet stages within about 30-year climate cycles) seem to be destroyed by climate warming, which might have great impact on vegetation and wildlife (Kirilyuk et al., 2012).

Vanishing permafrost is also causing serious concern. Permafrost underlies about one fourth of the land area of the Northern Hemisphere and dominates the landscape and ecosystems of the large tundra and boreal forest areas of northern Eurasia and North America, where it can reach thicknesses of more than $1000 \mathrm{~m}$. Formed in Siberia since the Late Pliocene/Early Pleistocene, permafrost has the largest extension in lowland regions, which were not glaciated during the Pleistocene, where permafrost never disappeared completely during warm phases (Schirrmeister, Hubberten, 2014). Permafrost is highly sensitive to a warming climate. The most significant increases in permafrost temperature were found in northern Alaska and in northern European Russia, increasing $2-3{ }^{\circ} \mathrm{C}$ between 1971 and 2010 (Kong, Wang, 2017).

Mongolia is located in the southern fringe of the Siberian permafrost zones, and permafrost occupies almost two-thirds of Mongolia, predominantly in the Khentei, Khovsgol, Khangai and Altai Mountains and surrounding areas. Most of the permafrost in Mongolia is at a temperature close to $0{ }^{\circ} \mathrm{C}$, and thus thermally unstable (Sharkhuu et al., 2007). Scenarios of climate change models predict that at the end of this century (2070-2099) continuous permafrost in Mongolia will be nearly gone and only remain in valleys of the mountains (Azzaya, Khaulenbek, 2008). There is strong concern about an increased degradation of mountain permafrost and a possible impact on river discharge and water availability. Decreased water availability from the mountains would have strong socio-economic implications for the population living in the steppe belt downstream the mountains (Menzel et al., 2016).

In summary, Mongolia is warming and becoming drier from year to year. Desertification and weather extremes will increase, and weather extremes are more severe. Decreasing permafrost will intensify desertification and deforestation in the steppe and taiga zones, respectively.

\section{Part II: The Eurasian steppe: Origin and evolutionary history}

\section{Origin of grasses and grassland biomes}

The history of the steppe biome is per se closely meshed with the origin of grasses and grassland biomes. Phylogeny of grasses (Poaceae), the origin of grassland biomes, and traits, which might have facilitated the global success of grasses, have been summarized and reviewed by Strömberg (2011), Kellogg (2015), and Linder et al. (2018). We focus on aspects, which we think are essential in the context of the evolutionary history of the Eurasian steppe.

\section{1 Origin and evolution of grasses}

There are ca. 10,000 grass species (Poaceae), which nearly all can be assigned to one of the two clades BEP (subfamilies Bambusoideae - Ehrhartoideae - Pooideae) and PACMAD (subfamilies Panicoideae - Arundinoideae - Chloridoideae Micrairoideae - Aristidoideae - Danthonioideae). These two clades are sister clades and represent the 'crown' or 'core' grasses, whereas three lineages are basal (Anomochlooideae, Pharoideae, Puelioideae) (GPWG II, 2012). The BEP clade comprises only grasses with the $\mathrm{C}_{3}$ photosynthetic pathway whereas in the PACMAD clade $\mathrm{C}_{3}$ and $\mathrm{C}_{4}$ photosynthesis grasses occur (Kellogg, 2015). The transition from the $\mathrm{C}_{3}$ to $\mathrm{C}_{4}$ photosynthesis pathway evolved 22-24 times independently in the PACMAD clade (with one possible reversion), with most transitions (16-18 times) in the subfamily Panicoideae (GPWG II, 2012). $\mathrm{C}_{4}$ grasses are mostly confined to tropical and subtropical climates in low latitudes and 
altitudes, whereas $\mathrm{C}_{3}$ species dominate the cooler temperate regions at higher latitudes and elevations. These patterns correlate strongest with minimum temperatures during growing seasons: low minimum temperatures favouring abundance of $\mathrm{C}_{3}$ grasses and high temperatures the abundance of $\mathrm{C}_{4}$ grasses (Teeri, Stowe, 1976). Regarding the Eurasian steppe, by far the majority of the grasses are $\mathrm{C}_{3}$ grasses of the Pooideae. The only widespread $\mathrm{C}_{4}$ grass in the Eurasian steppe is Cleistogenes squarrosa and Bothriochloa ischaemum.

Poaceae have been subject of numerous phylogenetic studies, but the time of origin and early diversification of the Poaceae is still under debate. On the one hand, taxon sampling, molecular dating methods, and molecular marker data sets (e.g., plastid vs. nuclear markers) may strongly influence phylogenetic inference and time divergence estimates. On the other hand, estimates of divergence times based on molecular data are strongly affected by fossil calibration points. The most reliable fossils of grasses are macrofossils such as leaves, stems, spikelets, and inflorescences. The oldest unequivocal remains of grasses are macrofossils from the Palaeocene/Eocene boundary (Crepet, Feldman, 1991), and from the Oligocene (Thomasson, 1987) from North America. Probable grass leaf cuticles from the Eocene and Oligocene are reported from Europe (Thomasson, 1987). Grass microfossils such as pollen and phytoliths (plant silica bodies) are reported from older strata but give rise to questions on homoplasy and preservation/identification the older they are (Jacobs et al., 1999). It would appear that the earliest firm record of grass pollen are from the Palaeocene of South America and Africa before ca. 60 and $55 \mathrm{Ma}$, respectively. The oldest report of grass fossils at all are phytoliths from late Cretaceous coprolites from India (Prasad et al., 2005). They seem to indicate considerable diversification of the grass family already by the upper Cretaceous, 67-65 Ma (Prasad et al., 2005, 2011). However, the identity of these phytoliths as grass fossils is questioned (e.g., Kellogg, 2015).

Macrofossils, pollen, and most phytolith data point to the origin of the grasses in the upper Cretaceous, about $80 \mathrm{Ma}$ (summarized in Kellogg, 2015). Incorporation of the Indian phytoliths as calibration points would place the origin of grasses considerably earlier, in the lower Cretaceous, about $125 \mathrm{Ma}$ (Vicentini et al., 2008; Prasad et al., 2011) or even in the upper Jurassic, about 114-180 Ma (Jones et al., 2014) which is critically discussed by Kellogg (2015). The origin of the core grasses (BEP and
PACMAD clades) from the basal lineages is placed at about 50-60 Ma (late Palaeocene - early Eocene) but again is strongly affected by fossil calibration points. Inclusion of the Indian phytolith evidence pushes this age to about 70 to $85 \mathrm{Ma}$ (upper Cretaceous) (Vicentini et al., 2008; Bouchenak-Khelladi et al., 2010, 2014a, b; Prasad et al., 2011; Christin et al., 2014; Jones et al., 2014).

The upper Cretaceous when the first grasses (Poaceae) seem to have originated and the Palaeocene-Eocene transition as the origin of the core grasses (BEP and PACMAD clades) are periods, when the global climate was generally warm and wet and no ice existed at the poles. The vegetation on Earth was dominated by tropical, warm temperate and cool temperate forests (Wolfe, 1985; Utecher, Mosbrugger, 2007). However, many regions at lower latitudes especially on Gondwana and SW Laurasia experienced arid climates (Scotese, 2000; Zhang et al., 2012). Molecular dating and habitat reconstructions let Bouchenak-Khelladi et al. (2014a) argue, that members of Poales originated in the early Cretaceous (118.4 Mya) in sunny and dry environments, and that in late Cretaceous ancestral members of the Poaceae diverged in shaded and dry habitats and invaded forest understorey, a view which is also held by Linder and Rudall (2005), Edwards and Smith (2010), Jones et al. (2014), and others. Some basal Poaceae (Anomochlooideae, Pharoideae, Puelioideae) are still found in deeply shaded forest understorey. Differing from dry habitats, Strömberg (2011) favours tropical wet forests as ancient Poacean habitats except for India.

The origin of $\mathrm{C}_{4}$ photosynthesis is dated along the Eocene-Oligocene transition 30-35 Mya (Christin et al., 2008; Vicentini et al., 2008; Strömberg, 2011; Bouchenak-Khelladi et al., 2014b; Cotton et al., 2015), and coincides with a steep declining of atmospheric $\mathrm{CO}_{2}$ and global cooling following Antarctic glaciation events (Beerling, Royer, 2011). It has often been argued that periods with declining atmospheric $\mathrm{CO}_{2}$ concentration and increasing global aridification would promote the evolution of $\mathrm{C}_{4}$ grasses (Sage, 2004 and literature cited therein; Christin et al., 2008; Vicentini et al., 2008; Bouchenak-Khelladi et al., 2009). Subsequent to the earliest origin of $\mathrm{C}_{4}$ photosynthesis, additional clustered origins occurred during or after the Oligocene (Vicentini et al., 2008; Christin et al., 2014) and would suggest more complex patterns and drivers of $\mathrm{C}_{4}$ origin and expansion (Edwards et al., 2010). The Indian phytolith-based ages for Poaceae result in a scenario by which $\mathrm{C}_{4}$ grasses appeared already 
in the Eocene when atmospheric $\mathrm{CO}_{2}$ was elevated (Zachos et al., 2008; Beering, Royer, 2011). This would need to reconsider potential environmental drivers for the evolution of the $\mathrm{C}_{4}$ pathway (Prasad et al., 2011).

As outlined, it is believed that grasses originated in a warm tropical or subtropical climate (Edwards, Smith, 2010), and the majority of grasses of the PACMAD clade today are adapted to a warm climate. Pooideae, which encompass the majority of Eurasian steppe grasses, and Danthonioideae, however, show cold tolerance. It has been argued that the climate cooling at the Eocene-Oligocene boundary could have triggered the evolution of cold tolerance in certain $\mathrm{C}_{3}$ lineages and would thus be a key innovation, which enabled certain $\mathrm{C}_{3}$ lineages to spread into cool temperate regions (Edwards, Smith, 2010; Edwards et al., 2010; Sandve, Fjellheim, 2010; Vigeland et al., 2013).

\subsection{Origin of grassland biomes}

Palaeobotanical evidence, phytolithic data, vertebrate fossils, isotopic records in fossils and palaeosols, palaeoclimate reconstructions and dated molecular phylogenetic inference are increasingly employed to understand the origin and evolution of grasslands. Phytolith microfossils now play an important part in tracing the origin and spread of grasses, and analysis of phytolith assemblages has become a powerful tool in reconstructing past environments and vegetation types as, e.g., forest vs. grassland (Strömberg, 2004, 2005, 2011).

The origin of grass-dominated ecosystems is comprehensively discussed in the literature (e.g., Jacobs et al., 1999; Bredenkamp et al., 2002; Edwards et al., 2010; Strömberg, 2011). Here, we will outline the essential features and address open questions before concentrating on the Eurasian steppe. The evolution of grasslands can be split into several major phases: (a) origin of $\mathrm{C}_{3}$ grasses (BEP and PACMAD clades) in the Palaeocene (see above); (b) origin of first $\mathrm{C}_{4}$ grasses along the Eocene-Oligocene transition (see above); (c) origin of $\mathrm{C}_{3}$ grassdominated open habitats in the late Oligocene and Miocene; (d) spread of $\mathrm{C}_{4}$ grass-dominated ecosystems in subtropical and tropical regions in the late Miocene-early Pliocene. This pattern is valid for all continents but there is variation among continents in the timing of grassland evolution. Whereas grassdominated ecosystems seem to appear in North America already by the late Oligocene, widespread grass-dominated ecosystems in northern continents did not occur until the early to middle Miocene, in
Australia even later (Jacobs et al., 1999; Strömberg, 2011). The grass-dominated habitats reported from the Eocene from South America (Patagonia) were, according to Strömberg et al. (2013), only minor floral elements in overall forested habitats. In all areas, grass-dominated vegetation was initially predominantly $\mathrm{C}_{3}$, but by 7-5 Mya $\mathrm{C}_{4}$ grasses prevailed everywhere in the lower tropical to subtropical latitudes except Australia (Jacobs et al., 1999; Strömberg, 2011).

\subsubsection{Time lag between origin and dominance of grasses}

It would appear that $\mathrm{C}_{3}$ and $\mathrm{C}_{4}$ grasses were present and diversified in many areas millions of years before they became dominant in open-grass habitats. This time lag provokes the question whether the gap between the emergence of $\mathrm{C}_{3}$ and $\mathrm{C}_{4}$ grasses and the proof of $\mathrm{C}_{3}$ and $\mathrm{C}_{4}$ grass-dominated open habitats is artificial due to poor fossil preservation and/or to the scarceness, smallness and patchy occurrence of open habitats. In other words, open habitats may have occurred much longer before they became ecological dominant, but this cannot be proved directly until yet. However, there is indirect evidence of open and dry habitats continuously from the Palaeogene to the Neogene (see below) justifying the assumption of suitable habitats for open-habitat grasses long before the grasses became dominant.

\subsubsection{Origin and spread of grass-dominated open habitats}

The emergence of grass-dominated open habitats covering large areas worldwide implies the question on the driving forces and can be finally put down to the question of what prevents tree growth. Temperature effects, as the length of the growing season, the annual sum of rainfall and its seasonal distribution, strongly influence tree growth. Beyond certain thresholds along the temperature gradient, aridity and seasonality favour the 'non-tree' climax formations savannas and steppe. Tree growth also depends on edaphic factors as nutrient-poor and nutrient-rich soils as well as on local relief characters. It also depends on disturbances as caused by fire and on large mammal herbivores. Vast areas of present day humid $\mathrm{C}_{4}$ grasslands and savannas have the climate potential to form forests. Without fire, closed forests would double from $27 \%$ to $56 \%$ of vegetated grid cells, mostly at the expense of $\mathrm{C}_{4}$ grasses but also of $\mathrm{C}_{3}$ shrubs and grasses in cooler climates (Bond et al., 2005; Bond, 2008). Hypsodonty (high-crowned teeth adapted to feeding on silica-rich or fibrous 
plants) of large mammal herbivores (ungulates) in the fossil record is conventionally taken as proof of open grass-dominated habitats. In North America and western Eurasia, hypsodonty evolved or became common several million years after open-habitat grasses dominated whereas in China, Africa and South America such a delay is not indicated by the fossil record (Jacobs et al., 1999; Strömberg, 2011). However, the evolution of hypsodonty does not necessarily coincide with the spread of grasslands since hypsodonty can also evolve in connection with other dietary, for instance abrasive leaf browsing (for discussion see Jacobs et al., 1999; Strömberg et al., 2013).

Relating these factors to palaeoclimates and palaeoenvironments, the following scenario emerges. The end of the Paleogene was characterized by a global cooling (Beerling, Royer, 2011; Figueirido et al., 2012). Rainfall was locally monsoonal (Huber, Goldner, 2012; Quan, Utescher, 2012) and therefore seasonal, indicating climates of open habitats (Utescher, Mosbrugger, 2007; Zhang et al., 2012). At the Paleogene-Neogene transition, aridity increased (Zachos et al., 2001, 2008) and may have reduced tree cover possibly also through increased fire (Bond et al., 2005; Bond, 2008). At the end of the Oligocene, global temperatures raised and first open grass-dominated habitats appeared, and they became dominant biomes during the Miocene and Pliocene (Jacobs et al., 1999; Bredekamp et al., 2002; Strömberg, 2011). The warm climate continued to the middle Miocene climate optimum followed by a cooling trend and increased seasonality culminating in the Pleistocene. It appears that convincing evidence of an increase in area of open and dry habitats from the early Eocene to the present has accumulated (Jacobs et al., 1999; Retallack, 2001; Strömberg, 2011; Bouchenak-Khelladi et al., 2014a, b).

\subsubsection{Spread of $\mathrm{C}_{4}$ grass-dominated open ha- bitats}

Emergence of $\mathrm{C}_{3}$ grass-dominated habitats seems to precede the spread of $\mathrm{C}_{4}$ grasslands by up to 20 million years. The spread of $\mathrm{C}_{4}$ grass-dominated open habitats at the late Miocene/early Pliocene at the expense of $\mathrm{C}_{3}$ grass-dominated open habitats in tropical and subtropical regions remains one of the less understood phases in the evolution of grassdominated ecosystems and is extensively discussed in the literature. Since the Eurasian steppe belt is situated outside subtropical latitudes and is dominated by $\mathrm{C}_{3}$ grasses, we will only shortly deal with the rise of $\mathrm{C}_{4}$ grasslands.
The appearance of $\mathrm{C}_{4}$ grassy ecosystems 6-8 Mya was not correlated with shifts between temperate and tropical biomes since grasses are believed to be a priori a warm-adapted clade (see above). Dominance of $\mathrm{C}_{4}$ grasses has been attributed to decreasing atmospheric $\mathrm{pCO}_{2}$, reductions in mean annual precipitation, and the development of seasonal climates (Edwards et al., 2010; Edwards, Smith, 2010). Above that, increased fire frequencies probably have been an additional major factor in the spread of $\mathrm{C}_{4}$ grass-dominated ecosystems (Cerling et al., 1993; Bond et al., 2005; Keeley, Rundel, 2005; Bond, 2008). This is corroborated by fossil charcoal records, which parallel the late Miocene expansion of $\mathrm{C}_{4}$ grasslands (Keeley, Rundel, 2005; Bond, 2008). Fire does not only limit trees in $\mathrm{C}_{4}$ grasslands but creates high light environments, which favour $\mathrm{C}_{4}$ grasses. The expansion of $\mathrm{C}_{4}$ grasslands is not strictly synchronous between continents and regions and leads one to assume complex and different ecological triggers between regions (Jacobs et al., 1999; Edwards et al., 2010; Strömberg, 2011).

\section{Climate and landscape history in the Cenozoic Era}

The Cenozoic climate history of Eastern Asia is a complicated and contentious issue and remains a matter of continuous debate, particular because of its bearing on the development of the East Asian monsoon system and the initial aridification in the Asian interior. Uplift of the Himalayan-Tibetan Plateau, changes in land-sea distribution and global climate trends have been invoked as driving forces behind Cenozoic palaeoclimate changes. However, there is little consensus about which one is the most important driver.

\subsection{Global Cenozoic climate}

Global climate during the Cenozoic era changed from ice-free poles and warm conditions in the Paleocene to ice-covered poles and cold conditions in the Neogene. This occurred in several steps. Long-term transitions and short-term changes are observed, and the overall cooling trend was interrupted by warming periods. The most pronounced climatic cooling event during the whole Cenozoic era was the Eocene-Oligocene transition (EOT), the transition from a 'greenhouse' to an 'icehouse' climate, followed by the cooling/ glaciation event at the Oligocene-Miocene boundary and the middle Miocene cooling (Zachos et al., 2001, 2008; Mudelsee et al., 2014, and literature therein). 
Geological and geographical events in the Cenozoic era strongly affected climate and vegetation patterns in extratropical Eurasia. Two marine seaway systems were of extraordinary importance for Cenozoic climate development, the North South stretching Arctic Sea - Tethys system of seas and straits, and the West - East stretching seas and straits of the Tethys and Paratethys. The uplift of the Himalayan-Tibetan Plateau has been invoked as one of the driving forces behind Cenozoic palaeoclimate changes in East and Central Asia.

\subsection{Tethys and Paratethys}

The Tethys Sea separated the supercontinents Laurasia in the North from Gondwana in the South. It began to form during the earliest part of the Mesozoic Era. With the break-up of Pangaea into Laurasia and Gondwana during the Jurassic, the Tethys gradually opened into a dominant marine seaway of the Mesozoic. Plate tectonic activities and the collision of India with Asia caused the destruction of the Western Tethys in the late Eocene. The Mediterranean and the intracontinental Paratethys basins came into existence. In the Eocene, the Paratethys spread from the Molasse basin north of the Alps eastwards up to the Tarim Basin in western China. Strong changes occurred in the history of the Paratethys. From an open ocean in the Eocene with connections to the Polar Sea via the Turgai Strait, it changed to an enclosed basin in the early Oligocene. The emerging mountain systems of the Alpine fold belt increasingly separated the Paratethys from the Mediterranean. By the middle Miocene the final disconnection of the Paratethys occurred (Rögl, 1998, 1999; Popov et al., 2004; Harzhauser, Piller, 2007) but Tethys - Paratethys connections remained extant (Popov et al., 2006). The central Paratethys (Pannonian basin) was isolated from the Eastern Paratethys at the beginning of late Miocene ca. 11.6 Mya (Ter Borgh et al., 2013) and became modified into a long-lived brackish lake-sea (Lake Pannon). Lake Pannon continuously shrank and disappeared during the Pliocene (Popov et al., 2006). During the late Miocene, the eastern Paratethys turned into an intracontinental brackish basin and was subdivided into two major basins, the Dacian-Euxinian basin system and the Caspian basin. Major deformation in the eastern Paratethys area and its surrounding mountain ranges occurred in the early Pliocene. The two basins existed as long-lived lake-seas until middle to late Pliocene (Akchagylian-Caspian basin) and middle Pleistocene (Karangation-Euxinian basin) (Popov et al., 2006). Remnants of the Para- tethys are from West to East the Black Sea, Azov Sea, Caspian Sea, Aral Sea and Lake Balkhash.

\subsection{Arctic Sea - Turgai Basin}

The West Siberian Turgai Basin stretched over $3500 \mathrm{~km}$ from the Aral Sea in the South to the recent Franz Josef Land and Severnaya Zemlya in the North and connected the open sea basins of the Arctic and Tethys. Opening, closure, widening and narrowing of these straits had a strong influence not only on marine ecosystems but also on land biota. The evolution of this system of epicontinental seas and straits started in the early Palaeocene. The connection of the Tethys with the Arctic Sea via the Turgai Strait enabled warm-water exchanges, and the different water masses (Arctic, Tethys and North Atlantic) affected direction of atmospheric currents and, therefore, heat transport and climatic fluctuations (Akhmetiev, Beniamovski, 2009; Akhmetiev, Zaporozhets, 2014). The West Siberian Sea and the Turgai Strait disappeared in the early Oligocene. When the straits became closed or land bridges were formed, animal and plant communities could migrate to the West and East of Eurasia more easily than before (Akhmetiev, Beniamovski, 2009; Akhmetiev et al., 2012; Akhmetiev, Zaporozhets, 2014).

\subsection{Uplift of the Tibetan Plateau}

The history of the Tibetan Plateau uplift and its effects on climate during Cenozoic time are still a matter of considerable debate (Renner, 2016 and literature therein). Evidence for the Tibetan Plateau uplift comes from a wide range of studies, including earth sciences, palaeoclimate and palaeoenvironmental studies, and climate simulations. In the light of recent studies, it would appear that the uplift is much older than previously assumed. It started after the Indian-Eurasian collision in the early Eocene (55-50 Mya), and the central Tibetan Plateau reached a height of ca. $4000 \mathrm{~m}$ already in the midEocene (Wang et al., 2008; Lippert et al., 2014). A proto-Tibetan Plateau probably developed already in Cretaceous - Paleogene time due to crustal thickening (Lippert et al., 2014). During the past $15 \mathrm{Ma}$, the Tibetan Plateau has grown outward on its northeastern and eastern sides, and northern Tibet may have risen higher (Molnar et al., 2010). The high mountain ranges to the North of the Tibetan Plateau have developed largely in mid- and late-Miocene time (Tian Shan, Altai-Sayan) or are thought to be at least of Oligocene age (Hangay Mts.) (Caves et al., 2014, 2017). However, elevation estimates for 
the Tibetan Plateau region may differ by kilometres depending on the proxy data used and on palaeogeography and climate models employed (van Hinsbergen, Boschman 2019).

\subsection{Onset of monsoonal circulation}

Climate in Eastern Asia is composed of humid (monsoon) climate in the East and South, arid and semi-arid climate in the North and its western parts. Three prominent features characterize the humid/ arid climates in East Asia: the East Asian summer monsoon, the South Asian (Indian) monsoon and the winter monsoon. The onset of monsoonal circulation has been placed in the Eocene (Licht et al., 2014; Caves et al., 2015), early Miocene (Guo et al., 2008; Lu, Guo, 2014), and late Miocene (An et al., 2001). Meanwhile, however, a Palaeogene age of monsoonal circulation can be regarded as definite. Recent evidence for strong Eocene monsoons indicated by varying oxygen isotope values in gastropod shells and mammalian teeth and aeolian dust deposition (Licht et al., 2014) is confirmed by climate proxy data from cyclic geochemical alternations in fossil oysters (Bougeois et al., 2018). Palaeobotanical data point to the origin of the Asian winter monsoon to at least late Oligocene (Sun, Wang, 2005), and convincing evidence accumulated to prove that the Asian winter monsoon existed by at least the early Miocene inferred by loess deposition in basins northwest of the Tibetan Plateau (Guo et al., 2002; Lu, Guo, 2014). A study by Srivastava et al. (2012) on a fossil megaflora suggest that the South Asian monsoon (Indian monsoon) was already established by late Oligocene times but probably existed as early as the early Eocene as evidenced by palaeobotanical and palaeozoological data (Shukla et al., 2014). The East Asian summer monsoon also existed by at least the late Oligocene evidenced by palaeobotanical data (Srivastava et al., 2012; Meng et al., 2018).

Origin of the winter monsoon and the East Asian monsoon are of particular importance for unravelling the evolutionary history of the semiarid steppe climate in Central Asia. The East Asian monsoon influences precipitation patterns of the MongolChinese steppe region in bringing summer rain. The winter monsoon-in-itself does not directly affect steppe climates. However, since the winter monsoon circulation is dominated by the Siberian High, which as a semi-permanent high-pressure system in winter time is a prerequisite for the steppe climate, the winter monsoon provides palaeoclimate proxy data for the strength and age of the Siberian High and thus steppe climate.

\subsection{Aridification of Central Asia}

With respect to the origin of the Eurasian steppe, the temporal and spatial development of a steppe climate (seasonal and semiarid climate) is of special importance. Establishment of arid conditions within interior Asia is thought to have occurred already during the Eocene (Dupont-Nivet et al., 2007; Bosboom et al., 2014; Li et al., 2018), Eocene-Oligocene transition (Sun et al., 2010; Sun, Windley, 2015), throughout the Neogene (Caves et al., 2016), early Miocene (Guo et al., 2002, 2008) and late Miocene (Sun et al., 2009; Liu et al., 2016). Researchers arguing for a Paleogene aridification onset, suggest that the Eocene climate of Asian continental interior was semi-arid and strongly seasonal, and retreat of the Paratethys and global cooling at the EoceneOligocene transition (EOT) affected Central Asia and caused enhanced aridification (Bosboom et al., 2014; Sun, Windley, 2015). Li et al. (2018), however, argue for global cooling and uplift of the Tibetan Plateau as main factors, and only insignificant role of land-sea redistribution, whereas Sun et al. (2014) claimed global cooling rather than tectonic uplift. It would appear that global cooling and retreat of the Paratethys Sea together with the uplift of the Tibetan Plateau were major factors in the initial aridification of Central Asia.

It has been suggested that the Paleogene climate in East Asia was dominated by a zonal pattern with a latitudinal arid/semiarid band stretching from the Chinese eastern coast (ca. $25-35^{\circ} \mathrm{N}$ latitude) to Central Asia (ca. $30-45^{\circ} \mathrm{N}$ latitude), and it has been argued that this so-called 'middle arid zone' was controlled to a large extent by desert and steppe climates (BWh and BSh climates in the KöppenGeiger climate classification system) (Zhang et al., 2012 and literature cited therein). However, according to Quan et al. $(2012,2014)$, the middle part of East Asia was apparently not covered by desert and/ or steppe vegetation during most of the Paleogene.

A renewed aridification step occurred in Central Asia at the end of the Oligocene/early Miocene. Miocene uplift of the Pamir, Tian Shan and Altai blocked the westerlies and led to enhanced aridification and recycling of precipitation patterns (Caves et al., 2016; Bougeois et al., 2018, and literature cited therein). Elevation of the Tian Shan and Altai during the Miocene created a seasonality boundary with predominantly spring and fall precipitation to the west (Kazakhstan) and primarily summertime precipitation to the east (NW China and Mongolia) (Caves et al., 2017). 
The aeolian red clay and loess deposits from the Chinese Loess Plateau in northern Central China are derived from Mongolia and were transported by winter monsoon in the late Oligocene/early Miocene to the Loess Plateau (Lu, Guo, 2014). The aeolian deposits from the Junggar Basin in northwestern China, however, are derived from Kazakhstan and were transported by westerly winds (Sun et al., 2010). They indicate that aridity in Kazakhstan started during the Paleogene (late Oligocene/early Miocene: Sun et al., 2010; early Oligocene after retreat of the Paratethys: Akhmetiev, Zaporozhets, 2014; Eocene: Velichko, 1999; Utescher, Mosbrugger, 2007).

\subsection{Paleogene vegetation in extratropical Eur- asia (Palaeocene to Oligocene) \\ 7.7.1 General features}

Vegetation belts in the Paleogene were mainly determined by the global climatic zonality. In the Northern Hemisphere, two main climate/vegetation belts can be distinguished, the Boreal zone (Boreal Flora) and the Tethys zone (Tethys Flora). The Boreal belt extended from the southward adjoining Tethys belt to the Polar region, the Tethys belt from its northern border with the Boreal belt to the northern rim of the Tethys in the South. Climate in the Boreal zone was warm and humid, and a subtropical to paratropical climate prevailed in the Tethys zone. However, the two seaway systems outlined above (Tethys - Paratethys and Arctic Ocean - Turgai Basin) strongly affected these zonal patterns. This situation caused distinct latitudinal temperature gradients in the western and eastern part of the Eurasian continent and led to a climate asymmetry of Eurasia during the Paleogene. With the vanishing Tethys during the second half of the Eocene, the Tethys Flora belt was reduced and finally disappeared.

In summarizing the major vegetation types and floras of the Paleogene in Eurasia, we rely mainly on Wolfe (1985), Mai (1995), Velichko (1999) and relevant chapters in Velichko and Nechaev (1999), Akhmetiev and Beniamovski (2009), Akhmetiev (2010), Akhmetiev and Zaporozhets (2014), Utescher and Mosbrugger (2007), and literature cited therein.

In the early Palaeocene in Eurasia, the Boreal - Tethys zonal border runs approximately from England - Balticum - Middle Ural - Altai - Mongolia - Primorye to Japan. Thus, a significant part was occupied by the Boreal zone characterized by a mesophyllous moderately thermophilic coniferous-broadleaved deciduous forest flora ('Tsagayan Flora'), particularly in the northern and eastern parts of the continent. In the Tethys zone, paratropical rainforests (mixture of temperate and tropical forest elements) prevailed in western and southern parts ('Gelinden Flora'). During the maximal warming in the late Palaeocene to early Eocene, the paratropical Tethys Flora extended to high latitudes and reached its maximal extension. It is characterized by a most thermophilous vegetation of polydominant broad-leaved forests. The second half of the Eocene is characterized by a long-term cooling trend. The paratropical rainforests of the Gelinden Flora were replaced and impoverished by subtropical evergreen laurophyllous vegetation and rainforests ('Poltavian (= Volhynian) Flora').

Seasonal subtropical monsoon-type floras developed in eastern Eurasia and extended northwards. These humid subtropical forests pushed back the Boreal forests. The late Eocene is generally characterized by relative low temperatures and aridization tendencies. In southerly regions of Kazakhstan and Central Asia, a sclerophyllous small-leaved shrub vegetation developed and expanded with a flora close to the 'Ancient Mediterranean Flora' sensu Takhtajan. At the end of the Eocene/beginning of Oligocene, the Antarctic glaciation induced the transition from the 'warm' to the 'cold' biosphere (see above). The Oligocene is marked by the notable expansion of the Boreal zone and the formation of temperate deciduous mesophyllous coniferousbroadleaved forests (Turgai Flora). The Turgai Flora occupied great parts of extratropical Eurasia and replaced the subtropical Tethys Flora in the middle and high latitudes of Eurasia. Evergreen plants disappeared. In the plains, formerly occupied by sea basins of the Paratethys, polydominant coniferous broad-leaved forests became the zonal vegetation types, which were replaced at the Oligocene/Miocene boundary by xerophyllous vegetation. This Old Mediterranean zone was the core of the ancient Mediterranean Miocene flora.

Despite the general cooling trend, the Paleogene was nevertheless a warm period with sea surface temperatures and terrestrial temperatures significantly higher than modern ones, at least in the early Paleogene (Bosboom et al., 2011; Hansen et al., 2013; Naafs et al., 2018 for review and summary). For northern Eurasia, terrestrial temperatures below $0{ }^{\circ} \mathrm{C}$ are reported not before the end of the Oligocene (Velichko, 1999). Thus, a modern steppe climate equivalent with hot summers and cold winters (temperatures well below $0{ }^{\circ} \mathrm{C}$ ) cannot be expected but arid and semiarid climates and steppe/savannah landscapes under a then higher temperature regime might well have developed. 
Subtropical subarid and arid regions were widespread in southern Europe, Southwest Asia and Central Asia (see chapter 7.6 above). In Kazakhstan and Central Asia there are signs of aridity in the first half of the Paleogene (Ephedra, Artemisia, Salicornia pollen). The belt of aridity moved to the South and became semiarid in the second half of the Eocene (Velichko, 1999). A small-leaved Lauraceae and Rhus shrub vegetation expanded and evaporites formed (Velichko, 1999). Utescher and Mosbrugger (2007), however, did not find indications for Eocene xerophytic vegetation types in the seasonally drier regions of southeastern Europe, western Asia and southern China. On the other hand, a steppe environment with xerophytic shrublands as indicated by Ephedra pollen constituted a large part of the Xining Basin in the northeastern Tibetan Plateau region. This arid landscape initially lacked typical Neogene and present Asian steppe elements such as Artemisia, Chenopodiaceae and Poaceae but these emerged and increased toward the Eocene-Oligocene Transition (Dupont-Nivet et al., 2008). Aridification of the Xining Basin in the late Eocene is also indicated by well-dated sediment records (Abels et al., 2011).

Across the EOT, large mammalian faunal turnovers and extinctions are documented for Europe ('Grande Coupure', e. g., Hooker et al., 2004) and Mongolia ('Mongolian Remodelling', Meng, McKenna, 1998). Open steppe formations at the EOT are reported from southwest Mongolia (Sun, Windley, 2015). Simultaneous changes in fauna, flora, and climate across the EOT in the Junggar Basin, northwestern China, indicate a change from a mixed coniferous - broad-leaved forest in a warm-humid climate to a forest-steppe landscape in a dry-temperate climate (Sun et al., 2014). The pollen flora of this ecosystem includes typical contemporaneous steppe elements (Artemisia, Ephedra, Poaceae, Cyperaceae, Chenopodiaceae, Asteraceae, Brassicaceae and others).

The Oligocene was characterized by recurring glacial episodes and a warming trend at the end of the Oligocene (Zachos et al., 2001; Pälike et al., 2006; Mudelsee et al., 2014). Stepwise aridification of Central Asia after the EOT climate cooling is indicated by major turnovers in Oligocene mammal faunal communities (Harzhauser et al., 2016). According to these authors, a semiarid steppe developed at the EOT in Mongolia, and during the early Oligocene, Serengeti-like mammal communities are recorded. An Oligocene woody savannah is also hypothesized for northern China (Gomes Rodrigues et al., 2012).
7.7.2 Synopsis of Paleogene climate and vegetation history in extratropical Eurasia

A synopsis of the extratropical Eurasian climate and landscape changes and vegetation history during the Paleogene is presented in Table 1, based mainly on Mai (1995), Velichko (1999), Akhmetiev and Beniamovski (2009), Akhmetiev (2010), Gomes Rodrigues et al. (2012), Akhmetiev and Zaporozhets (2014), Sun et al. (2014), Sun and Windley (2015), Harzhauser et al. (2016), and Popova et al. (2017).

\subsection{Neogene vegetation in extratropical Eurasia (Miocene to Pliocene) \\ 7.8.1 Neogene climate/landscape history}

The Neogene (ca. 23-2.6 Mya) is an especially important time period for the formation of the Eurasian steppe belt. During this time, major reorganizations of climate, continents, mountain ranges and oceans occurred in northern Eurasia. These events resulted in the redistribution of precipitation on a continental scale, with some areas drying and others becoming more humid, and affected the distribution of vegetation and mammals. The Miocene was the phase ('precursor') that predetermined the beginning of the presentday zonal structure of the landscape. Especially the late Miocene (ca. 11-5 Mya) was a time of large changes, and a continent-wide restructuring of the distribution of environments. At the end of the Miocene a new zonal structure component appeared - a zone of steppe (Velichko, 1999).

Fossil plants provide one of the best proxy data for palaeoenvironmental reconstructions. Palynological evidence as well as plant macrofossils for forest-steppe and steppe biomes in Neogene Eurasia are numerous, especially documented in the Russian literature. Several methods have been developed to reconstruct palaeovegetation and palaeoenvironments from palaeobotanical proxies and models (Francois et al., 2017). Mammals as consumers of vegetation have also been used to describe and reconstruct palaeoenvironments for at least a century. As a rule, mammal proxy data (for instance hypsodonty values of fossil mammals) seem to agree with paleovegetation data, showing similar large-scale patterns and estimated precipitation values (Eronen, 2006; Eronen et al., 2010; Fortelius et al., 2014).

In the early Miocene most areas of the Eurasian continent were humid and forested, only Central Asia had some areas of drier environment (see chapter 7.6). A general drying trend started in Eurasia around the middle Miocene (ca. 15-11 Mya). Landscape 
Table 1

Synopsis of Paleogene climate and vegetation in extratropical Eurasia

\begin{tabular}{|c|c|c|}
\hline $\begin{array}{c}\text { Series/ } \\
\text { Subseries }\end{array}$ & $\begin{array}{c}\text { Western Eurasia } \\
\text { (west of Turgai Basin) }\end{array}$ & $\begin{array}{c}\text { Eastern Eurasia } \\
\text { (east of Turgai Basin) }\end{array}$ \\
\hline $\begin{array}{c}\text { Oligocene } \\
(33.9-23 \mathrm{Ma})\end{array}$ & $\begin{array}{l}\text { Decreasing temperature; warm-temperate } \\
\text { forests with subtropical elements } \\
\text { widespread, evergreen plants disappeared } \\
\text { at the end of the Oligocene; 'Turgai Flora' } \\
\text { in some regions; }\end{array}$ & $\begin{array}{l}\text { Decreasing temperature, with frost in } \\
\text { Kazakhstan and Central Asia; deciduous } \\
\text { mesophyllous coniferous-broadleaved } \\
\text { forest widespread ('Turgai Flora'), } \\
\text { evergreen plants disappeared; stepwise } \\
\text { aridification, steppe/savannah landscapes in } \\
\text { Central Asia; } \\
\text { Pronounced global cooling at EOT and } \\
\text { faunal turnover ('Mongolian Remodelling') }\end{array}$ \\
\hline $\begin{array}{l}\text { Late Eocene } \\
(38-33.9 \mathrm{Ma})\end{array}$ & $\begin{array}{l}\text { Subtropical evergreen laurophyllous and } \\
\text { rainforest vegetation prevailed }\end{array}$ & $\begin{array}{l}\text { Subtropical monsoon-type forests } \\
\text { widespread; } \\
\text { 'Ancient Mediterranean Flora' in } \\
\text { Kazakhstan and Central Asia; steppe } \\
\text { landscapes in Central Asia }\end{array}$ \\
\hline $\begin{array}{l}\text { Middle Eocene } \\
(47.8-38 \mathrm{Ma})\end{array}$ & \multicolumn{2}{|c|}{$\begin{array}{l}\text { Cooling trend, Tethys Flora disappeared, replaced by subtropical evergreen vegetation } \\
\text { ('Poltavian Flora') }\end{array}$} \\
\hline $\begin{array}{l}\text { Early Eocene } \\
(56-47.8 \mathrm{Ma})\end{array}$ & \multicolumn{2}{|c|}{ Maximal extension of Tethys Flora; Cenozoic climatic optimum } \\
\hline $\begin{array}{l}\text { Paleocene } \\
(66-56 \mathrm{Ma})\end{array}$ & \multicolumn{2}{|c|}{$\begin{array}{c}\text { Tethys Flora prevailed in western Eurasia - Boreal Flora prevailed in eastern Eurasia } \\
\text { Climate asymmetry between western and eastern Eurasia } \\
\text { Northern 'Boreal Flora': coniferous-broadleaved deciduous forests ('Tsagayan Flora'); } \\
\text { humid warm-temperate climate; } \\
\text { Nouthern 'Tethys Flora': paratropical rainforests ('Gelinden Flora'); humid subtropical- } \\
\text { like climate; }\end{array}$} \\
\hline
\end{tabular}

Notes: Standard chronostratigraphy, see Table 2. For References see Text. Table is not scaled to geological time.

opening in many areas of Eurasia appears to be linked with Late Neogene cooling and went along with an increasing seasonality of precipitation and continentality of the palaeoclimate. Forests were replaced by woodlands and grasslands, particularly at mid-latitudes (van Dam, 2006; Utescher et al., 2011, and literature cited therein). This is in line with the global Cenozoic climate history, which shows a clear trend towards a globally drier state, as indicated by the worldwide development and expansion of grassland and desert ecosystems in the Neogene (Retallack, 2001). The ultimate causes of this global aridification are not yet fully understood, although it is commonly believed that there is a general relation with the global Cenozoic cooling.

During the late Miocene, arid conditions, seasonal climates and open environments spread at a continental scale, and mammal communities adapted to open country developed. At the end of the Miocene, typical steppe animals are recorded from eastern and southeastern Europe (Mai, 1995). They belong to the so-called 'Pikermian chronobiome' (Hipparion or Pikermi fauna), named after the small village Pikermi near Athens, Greece. The Pikermi fauna assemblage is characterized by a great diversity of horses, rhinoceroses, antelopes, giraffes, relatives of elephants, hyenas, cats and many other mammals, and by a poor representation of deer. The Pikermi fauna of various regions differed in genus and species composition. In Eurasia, the core area of the Pikermian chronofauna was south of the Paratethys from the Balkans to Afghanistan, but it ranged much further to East Asia and northeastern Africa (Eronen et al., 2009). At its maximal distribution centred on mammal zone MN12 (8.0-6.7 Mya, see Table 2), it was widely distributed also in temperate latitudes throughout Europe and Central Asia. During the early Pliocene (MN14 and MN15, 5.3-3.2 Mya, Table 2), the Pikermian fauna vanished from Eurasia (Eronen et al., 2009). 
The Pikermian chronobiome is often taken as a proxy for a steppe/savannah landscape. Several authors have reconstructed the 'Pikermian palaeobiome' as a seasonal woodland mosaic including areas with extensive tree cover, open grassy and herbaceous habitats, and shrubland (Eronen et al., 2009 and literature cited therein). An "Old World savannah palaeobiome" has been suggested by Kaya et al. (2018), which developed in central and western Asia and expanded with increasing aridity to its maximal peak 9-6 Mya. It is also argued that the Pikermian chronofauna may have lived in different biomes, including temperate forests, forest-steppe, steppes/savannahs, and shrubland (Denk et al., 2018; see also Kovar-Eder et al., 2006; Eronen et al., 2010).

Table 2

Neogene Standard chronostratigraphy, correlation with Eurasian regional stages and Neogene mammal zones

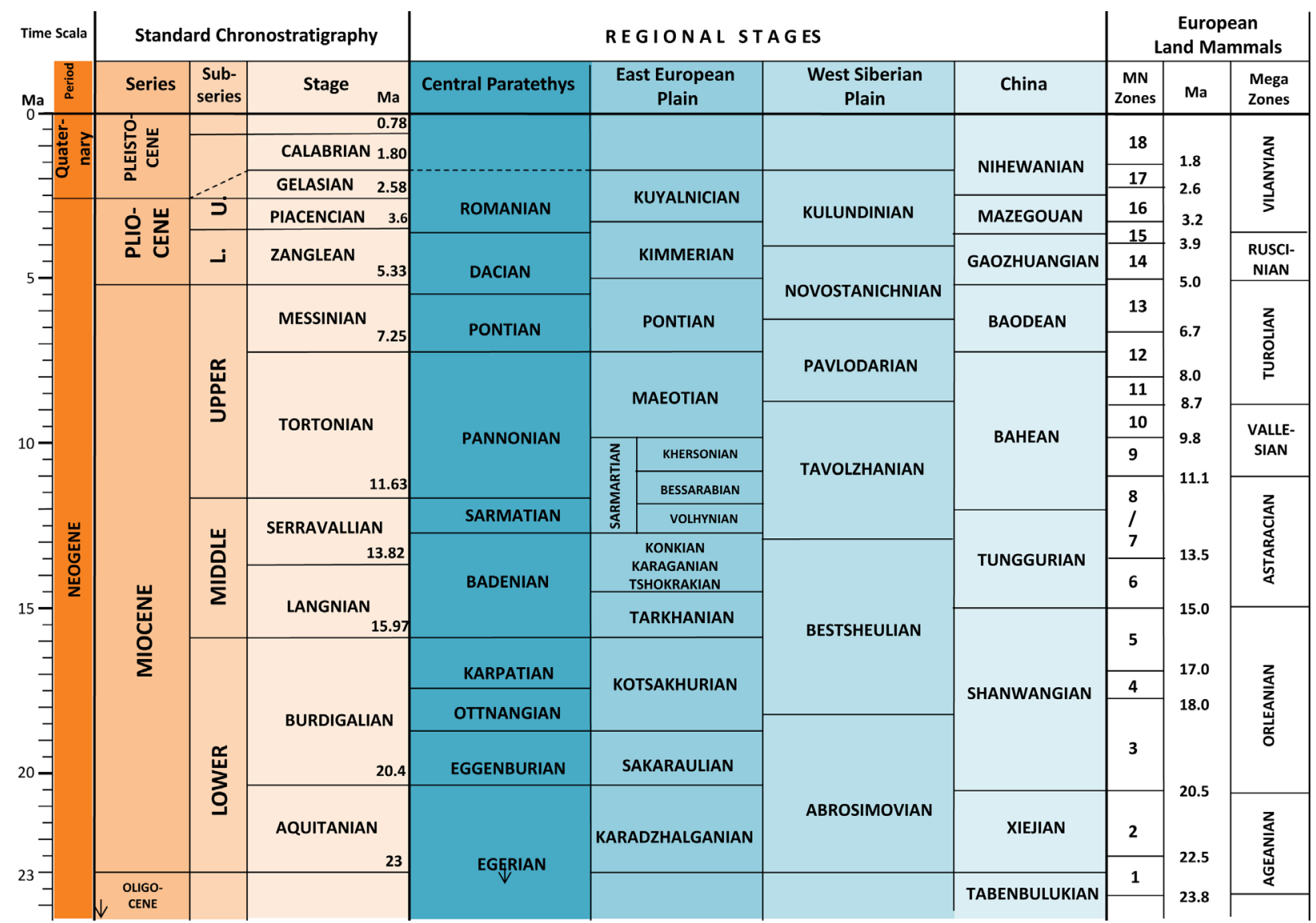

References: Standard Chronostratigraphy: International Chronostratigraphic Chart. http://www.stratigraphy.org/ index.php/ics-chart-timescale;

Central Paratethys and Eastern Paratethys adopted from Rögl (1998) and Steininger, Wessely (2007); West Siberian Plate: adapoted from Akhmetiev (2005) and Popova et al. (2012); China: Deng, Hou (2014), see also Wang et al. (2013).

7.8.2 Synopsis of Neogene climate and vegetation history of the Mongol-Chinese steppe region

Standard chronostratigraphy and correlation with Eurasian regional stages are presented in Table 2. A synopsis of the climate and landscape changes and vegetation histories during the Neogene is presented in Table 3, and is based mainly for northern China and adjacent Mongolia on Jia et al. (2003), Fortelius et al. (2006), Jiang and Ding (2009), Liu et al. (2009, 2011), Utescher et al. (2011), and Jacques et al. (2013), and for the Asian interior and Baikal region on Erbajeva and Alexeeva (2013).

7.8.3 Synopsis of Neogene climate and vegetation history of the Euro-Siberian steppe region

Standard chronostratigraphy and correlation with Eurasian regional stages are presented in Table 2. A synopsis of the climate and landscape changes and vegetation histories during the Neogene is presented in Table 4 and is based mainly on the following literature. 
Table 3

Synopsis of Neogene climate and vegetation in the Mongol-Chinese steppe region

\begin{tabular}{|c|c|c|}
\hline $\begin{array}{c}\text { Series/ } \\
\text { Subseries } 1)\end{array}$ & $\begin{array}{l}\text { Northern and western China } \\
\text { (and adjacent Mongolia) }^{2)}\end{array}$ & Baikalian Region ${ }^{3)}$ \\
\hline $\begin{array}{c}\text { Pliocene } \\
(5.3-2.6 \mathrm{Ma})\end{array}$ & $\begin{array}{l}\text { Western China is arid, aridification of north China, } \\
\text { strengthening of the winter monsoon, Pliocene } \\
\text { cooling. } \\
\text { Replacement of forests by forest-steppe and steppe, } \\
\text { increase in deciduous and herb components in } \\
\text { north and northeast China }\end{array}$ & $\begin{array}{l}\text { Cooling and aridity increased but } \\
\text { climate was still mild } \\
\text { Forests were gradually replaced } \\
\text { by forest-steppe and steppes; most } \\
\text { thermophilic elements disappeared }\end{array}$ \\
\hline $\begin{array}{c}\text { Upper Miocene } \\
(11.6-5.3 \mathrm{Ma})\end{array}$ & $\begin{array}{l}\text { Increasing aridity in western and central China, } \\
\text { aridisation in north China; at the end a cool and } \\
\text { humid episode } \\
\text { Forests and increasing steppe vegetation, reversed } \\
\text { development during cooler episode }\end{array}$ & $\begin{array}{l}\text { Climate warm and humid but trend } \\
\text { towards cooling and aridification } \\
\text { Broad-leaved and mixed coniferous } \\
\text { forests, open landscapes extended }\end{array}$ \\
\hline $\begin{array}{l}\text { Middle Miocene } \\
(16-11.6 \mathrm{Ma})\end{array}$ & $\begin{array}{l}\text { North China humid and warm, extension of drier } \\
\text { areas from western China to the east. } \\
\text { Mixed mesophytic forests; at the end of Middle } \\
\text { Miocene, steppe vegetation dominated in northwest } \\
\text { China }\end{array}$ & $\begin{array}{l}\text { Climate similar to Lower Miocene } \\
\text { Vegetation similar to Lower } \\
\text { Miocene }\end{array}$ \\
\hline $\begin{array}{c}\text { Lower Miocene } \\
(23-16 \mathrm{Ma})\end{array}$ & $\begin{array}{l}\text { Western China humid, later increasing aridity in } \\
\text { western China } \\
\text { At beginning evergreen and deciduous forests, later } \\
\text { more open vegetation, increase in herb component }\end{array}$ & $\begin{array}{l}\text { Warm and moist climate } \\
\text { Broad-leaved/coniferous forests } \\
\text { widespread, but also forest-steppe } \\
\text { and restricted steppe landscapes }\end{array}$ \\
\hline
\end{tabular}

Notes: ${ }^{1)}$ Standard chronostratigraphy, see Table 2 . For references ${ }^{2), 3)}$ see the text.

Table is not scaled to geological time.

References for eastern and southeastern Europe: Mai (1995), Velichko (1999), Velichko et al. (1999), Popescu (2006), Syabryaj et al. (2007), KovarEder et al. (2008), Bruch et al. (2011), Ivanov et al. (2011), and Utescher et al. (2011). References for the West Siberian and Kazakh Plains: Akhmetiev et al. (1999), Arkhipov et al. (1999), Velichko (1999), Bruch and Zhilin (2007), and Popova et al. (2012, 2013, 2017).

\section{Climate and landscape history in the Pleistocene}

\subsection{Pleistocene classification systems and cli- mate history}

The Quaternary (Pleistocene and Holocene) is characterized by the development of widespread glaciations in temperate mid-northern latitudes and by associated physical and biotic readjustments. In the context of progressive Cenozoic cooling, the onset of significant Northern Hemispheric glacia- tions started 2.8-2.4 Mya. Based on this evidence, the base of the Pleistocene and thus the beginning of the Quaternary period/end of the Neogene has been recently shifted by the International Commission on Stratigraphy ICS from the base of the Calabrian stage (1.8 Mya) to the base of the Gelasian stage (2.58 Mya; Gibbard, Head, 2009). This issue is of considerable relevance for our discussions since Quaternary system classifications are different depending on when they were compiled. In addition, traditional Russian terminology of Pleistocene chronostratigraphic units differs from the standard ICS terminology. Table 5 presents correlation between the ICS chronostratigraphical units and those used in Western Europe, East European Plain and Siberian Plain as well as Marine Isotope Stages (MIS). Isotope studies from the bottom sediments of the World's oceans have indicated that as many as 52 cold and interspersed warm climate periods occurred during the last 2.6 million years. In contrast to the deep sea, continental evidence is 
so incomplete and regional variable that terrestrial glacial-interglacial stratigraphies must refer to the ocean record for a global chronological foundation (Cohen, Gibbard, 2011).

Table 4

Synopsis of Neogene climate and vegetation in the Euro-Siberian steppe region

\begin{tabular}{|c|c|c|c|}
\hline $\begin{array}{c}\text { Series/ } \\
\text { Subseries }^{1)}\end{array}$ & $\begin{array}{c}\text { Eastern and } \\
\text { Southeastern Europe }{ }^{2)}\end{array}$ & $\begin{array}{c}\text { West Siberian } \\
\text { Plain }^{3)} \\
\end{array}$ & $\begin{array}{c}\text { Kazakhstan } \\
\text { Plains }^{4)} \\
\end{array}$ \\
\hline $\begin{array}{c}\text { Pliocene } \\
(5.3-2.6 \mathrm{Ma})\end{array}$ & $\begin{array}{l}\text { Frequency of cooling phases } \\
\text { increased; aridity in cool } \\
\text { epochs; continentality and } \\
\text { aridity increased sharply } \\
\text { from west to east; } \\
\text { Mixed coniferous forests in } \\
\text { warm, steppe in cool epochs }\end{array}$ & $\begin{array}{l}\text { Climate similar to modern } \\
\text { one, only slightly different; } \\
\text { Spreading of dry steppes } \\
\text { and semi-deserts, close to } \\
\text { modern analogous }\end{array}$ & $\begin{array}{l}\text { Dry and wet climate phases, } \\
\text { basic cooling in } 2^{\text {nd }} \text { half of } \\
\text { the Pliocene } \\
\text { Vegetation similar to } \\
\text { southern parts of West } \\
\text { Siberian and East European } \\
\text { plain }\end{array}$ \\
\hline $\begin{array}{c}\text { Upper } \\
\text { Miocene } \\
(11.6-5.3 \mathrm{Ma})\end{array}$ & $\begin{array}{l}\text { Slight cooling and drying; } \\
\text { humid/drier and warmer/ } \\
\text { cooler cycles; increasing } \\
\text { seasonality, continental } \\
\text { climate in east Europe; } \\
\text { Forest in the north, forest- } \\
\text { steppe in the south; true } \\
\text { steppe only along Black and } \\
\text { Caspian Sea }\end{array}$ & $\begin{array}{l}\text { Boreal warm-temperate } \\
\text { climate, change to drier } \\
\text { conditions; semi-arid to arid } \\
\text { climates; } \\
\text { Forests were replaced by } \\
\text { forest-steppe in the north, } \\
\text { further south dry steppes } \\
\text { and semi-deserts on saline } \\
\text { soils }\end{array}$ & $\begin{array}{l}\text { Warm and dry climate, } \\
\text { southern regions more arid } \\
\text { than northern } \\
\text { Dry steppe and semi-desert } \\
\text { landscapes }\end{array}$ \\
\hline $\begin{array}{c}\text { Middle } \\
\text { Miocene } \\
(16-11.6 \mathrm{Ma})\end{array}$ & $\begin{array}{l}\text { Climate optimum, } \\
\text { subtropical to warm- } \\
\text { temperate; } \\
\text { Mixed coniferous and/or } \\
\text { broad-leaved forests }\end{array}$ & $\begin{array}{l}\text { Climatic optimum in } \\
\text { whole Siberia; longitudinal } \\
\text { temperature gradient from } \\
\text { western Siberia to warmer } \\
\text { conditions in the west; } \\
\text { Opening of landscape, } \\
\text { spread of post-Turgai } \\
\text { forested steppe }\end{array}$ & $\begin{array}{l}\text { Climate more continental } \\
\text { and higher seasonality; } \\
\text { intensified aridization } \\
\text { Forest-steppe but herb- } \\
\text { and grass-rich coenoses } \\
\text { prevailed }\end{array}$ \\
\hline $\begin{array}{c}\text { Lower } \\
\text { Miocene } \\
(23-16 \mathrm{Ma})\end{array}$ & $\begin{array}{l}\text { Warm and humid; } \\
\text { Mixed coniferous and/or } \\
\text { broad-leaved forests }\end{array}$ & $\begin{array}{l}\text { Mixed coniferous and/or } \\
\text { broad-leaved forests }\end{array}$ & $\begin{array}{l}\text { Warm-temperate, trend } \\
\text { to seasonality and } \\
\text { continentality, beginning } \\
\text { aridization; } \\
\text { Forests of Turgai type, } \\
\text { forest- steppe and } \\
\text { 'prototypes of steppe' } \\
\text { (herbaceous coenoses) } \\
\text { appeared }\end{array}$ \\
\hline
\end{tabular}

Notes: ${ }^{1)}$ Standard chronostratigraphy, see Table 2. For references ${ }^{2), 3), 4)}$ see text. Table is not scaled to geological time.

In the Early Pleistocene, global temperatures gradually cooled until roughly 1.2 Mya and cooling then stalled until the present (Snyder, 2016). The time between ca. 1.2 and 0.5 Mya, known as 'Mid-Pleistocene transition' (Head et al., 2008b), was a transition period in which low-amplitude ca. 41-ka climate cycles of the earlier Pleistocene were replaced progressively by high-amplitude quasi 100-ka cycles. The latter variability begins at ca. 1.2 Mya, strengthens at ca. 1.0-0.9 Mya, and intensifies about 700-650 kya. Climatic cycles after about 700 kya were conspicuously asymmetrical ('sawtoothed' pattern) indicating slow ice build-up and subsequent rapid melting (Head et al., 2008b). This 
Table 5

Pleistocene standard chronostratigraphy and correlation with Eurasian regional stages. Marine Isotope Stages are indicated

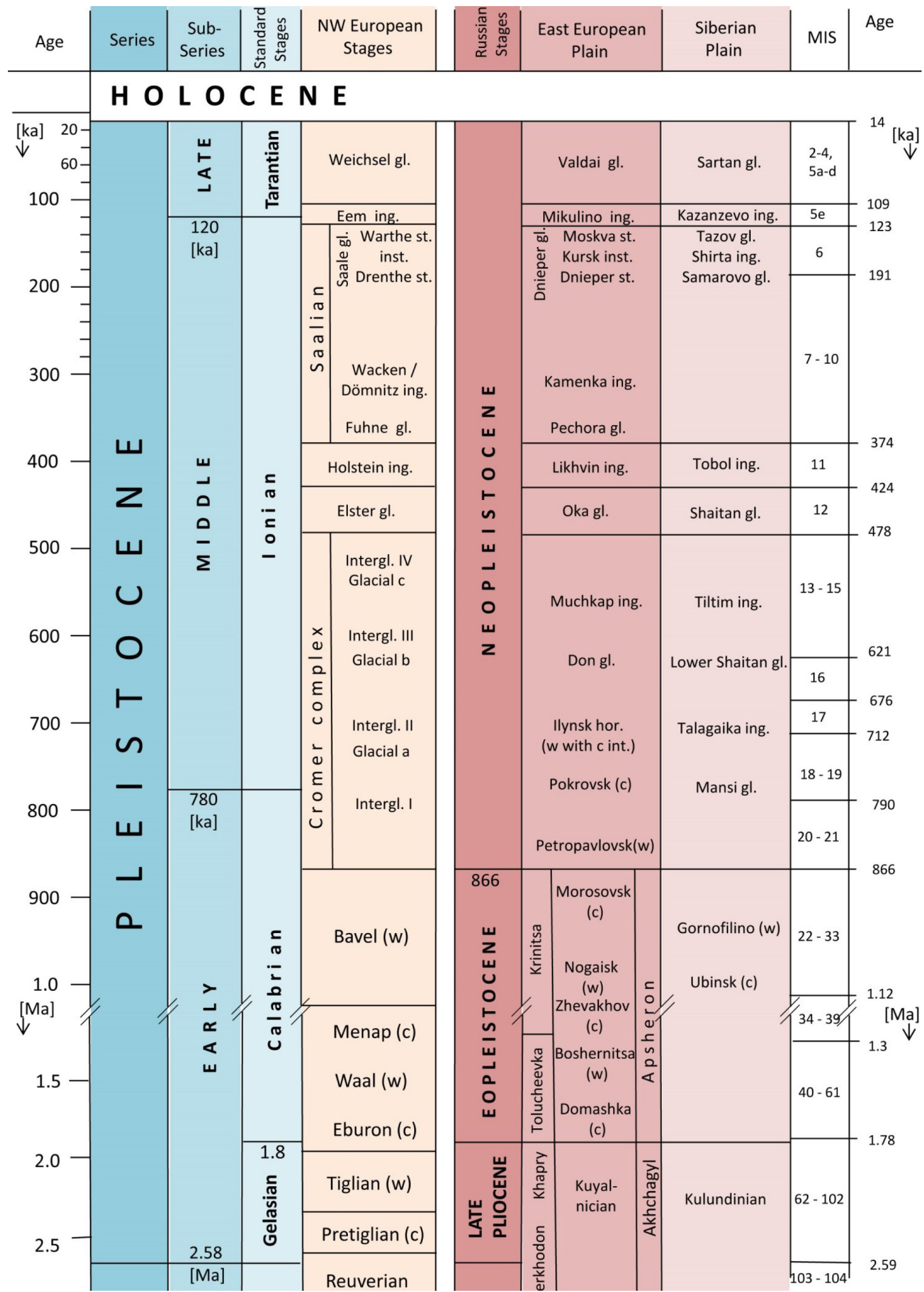

Abbreviations: MIS - Marine Isotope Stages; c - cold, w - warm; hor. - Horizon; Intergl., ingl. - interglacial; gl. glacial; inst. - interstadial, st. - stadial; int. - intervals.

References: Cohen, Gibbard (2011). Russian regional stages and their correlation with the standard chronostratigraphy are based on Cohen, Gibbard (2011), and on Velichko et al. (2005). 
Early-Middle Pleistocene transition, through the increased severity and duration of cold stages, had a profound effect on the biota and the physical landscape, especially in the northern hemisphere.

\subsection{Pleistocene landscape history}

At the end of the Pliocene, various types of forest vegetation were characteristic for northern Eurasia, mixed forests of conifers and deciduous broadleaf trees in Europe, broad-leaved forests of several conifer taxa in Siberia. Forest steppe was widespread in southeastern Europe and western Siberia, whereas treeless steppe seems to have been confined to the dry regions of Middle and Central Asia (Frenzel, 1968a; Velichko, 1999). At the beginning of the Pleistocene (MIS 103, see Table 5) the climate began to cool down significantly initiating the first glacial period of the Pleistocene. Forests disappeared in most regions of northern Europe and western Siberia and were replaced by various steppe formations. Only in eastern Siberia coniferous forests survived. In northern Eurasia, glacial periods were characterized by maximum distribution of various steppe communities, and interglacial periods were characterized by forests, which covered the Eurasian continent from the Atlantic coast in the West to the coast of the Okhotsk and Japanese seas in the East (Frenzel, 1968a, b; Velichko, 1999). "The recent vegetation of northern Eurasia resulted from a relentless contest between steppe and forest" (Frenzel, 1968b). Major events during the Pleistocene in Eurasia are presented in Table 6, based mainly on Velichko (1999), Head et al. (2008a, b), Dolukhanov et al. (2009), Ehlers and Gibbard (2011), and on literature cited therein.

\section{Major events during the Pleistocene in northern Eurasia}

\begin{tabular}{|c|c|}
\hline $\begin{array}{l}\text { Geological time } \\
\text { (corresponding MIS } \\
\text { stages) }\end{array}$ & Climate/landscape and biotic events \\
\hline $\begin{array}{c}130 \text { to } 10 \text { ka } \\
\text { Late Pleistocene } \\
\text { (MIS } 5 \text { to MIS 2) }\end{array}$ & $\begin{array}{l}\text { Severity of continental climate reached a maximum, maximal spread of cryolithic } \\
\text { zone, maximum loess deposition; glacial systems were reduced from west to east; } \\
\text { open-arid landscapes dominated like tundra-steppe, semi-deserts, deserts; landscape } \\
\text { zones shifted to south by } 10^{\circ} \text { latitude; mammoth fauna complex fully developed; } \\
\text { Khazarian and Khvalynian transgressions of Caspian Sea }\end{array}$ \\
\hline $\begin{array}{l}850 \text { ka to ca.130 ka } \\
\text { Middle Pleistocene } \\
\text { (MIS } 21 \text { to MIS 6) }\end{array}$ & $\begin{array}{l}\text { Waves of deep cooling and warming; intensified development of permafrost, loess } \\
\text { and glaciers/ice sheets; major continental glaciations; from ca. } 625 \text { ka onwards } \\
\text { (MIS 16) high amplitude climate systems, highly asymmetrical variability; radical } \\
\text { transformation of the zonal landscape structure; around } 850 \text { to } 700 \text { ka spread of } \\
\text { large mammals across northern Eurasia, steppe mammoth first appeared; Baku } \\
\text { transgression of Caspian Sea }\end{array}$ \\
\hline $\begin{array}{l}1.8 \text { Ma to ca. } 850 \text { ka } \\
\text { Upper Early } \\
\text { Pleistocene } \\
\text { (MIS } 61 \text { to MIS 22) }\end{array}$ & $\begin{array}{l}\text { Increasing long-term global ice volume, spread of permafrost, beginning } \\
\text { dominance of periglacial components; about } 1 \text { Ma onset of quasi 100-kyr cycles } \\
\text { and development of continental ice sheets; 'prototypes' of periglacial steppes during } \\
\text { cold phases; Apsheron transgression of Caspian Sea }\end{array}$ \\
\hline $\begin{array}{l}2.6 \text { to } 1.8 \mathrm{Ma} \\
\text { Lower Early } \\
\text { Pleistocene } \\
\text { (MIS } 104 \text { to MIS 62) }\end{array}$ & $\begin{array}{l}\text { Overall cooling and climate seasonality, opening of landscapes; onset of severe } \\
\text { climate deterioration in NW Europe; strong aridification, expansion of deserts, } \\
\text { major loess-palaeosol deposition in Central Asia; herbivore turnover between } 2.6 \\
\text { and } 2.2 \mathrm{Ma} \text {, appearance of modern ruminants; Akhchagyl transgression of Caspian } \\
\text { Sea }\end{array}$ \\
\hline $\begin{array}{c}2.7 \mathrm{Ma} \\
\text { end of Pliocene }\end{array}$ & $\begin{array}{l}\text { Synchronous glaciation of Greenland, Scandinavia and North America; weakening } \\
\text { of summer monsoon in Central Asia; change from subtropical to boreal vegetation } \\
\text { in central Europe; Akhchagyl transgression of Caspian Sea }\end{array}$ \\
\hline
\end{tabular}

Notes: Geological time, chronostratigraphical units and MIS stages in accordance with Pleistocene standard chronostratigraphy, see Table 5. Abbreviations: Ma - million years ago; ka - thousand years ago; LGM - Last Glacial Maximum; MIS - Marine Isotope Stages.

Main literature: Velichko, 1999; Head et al., 2008a, b; and literature cited therein. Table is not scaled to geological time. 
The climatic macrocycles in eastern Europe and Siberia were associated with latitudinal shifts of the steppe belt (Devyatkin, 1993; Arkhipov, Volkova, 1994; Akhmetiev et al., 1999; Arkhipov et al., 1999; Velichko et al., 1999; Tarasov et al., 2000b). The steppe belt also faced significant longitudinal splits during the ice ages. These were caused by transgressions of the Caspian Sea north to the southern Ural Mountains and the Volga-Kama basin (Dolukhanov et al., 2009; Tudryn et al., 2013; Yanina et al., 2018, and literature cited therein), see Table 6. Ice damming of the $\mathrm{Ob}$ - Irtysh - Tobol river system by northern glaciers advancing far to the South followed by backwaters reaching the foothills of the Kazakhstan Highlands and of the Altai Mountains was another factor (Arkhipov, Volkova, 1994; Arkhipov et al., 1995, 1999; Tudryn et al., 2013).

The climatic macrocycles during the Pleistocene had far-reaching consequences for earth's geomorphology and distribution of vegetation zones. This is particularly obvious for the last ice age (MIS 5e 2). Time since the last glacial maximum and the beginning of the following global warming is short so that the glacial geomorphological surface structures in many parts of the world are still clearly visible and present-day vegetation would mirror to a certain extent interglacial vegetation belts, if humankind would not have severely disturbed and changed the natural vegetation and their habitats. The Pleistocene, especially Late Pleistocene, has a key position in understanding preceding and present-day geographical distribution, structure and floristic composition of the Eurasian steppe belt. We, therefore, deal with the Late Pleistocene-Holocene paleoclimates and palaeoenvironments of the Northern Hemisphere in more detail.

\subsection{Late Pleistocene classification systems and climate/landscape history}

During the last glacial maximum (LGM), ca. 21-20 kyr cal BP, western and central Siberian lowlands remained ice-free (Astakhov, 2013). In northern and northeastern Siberia, glaciation was largely restricted to the mountains (Putorana and Verkhoyansk Mts.). In Europe, the southern part of the Scandinavian ice shield stretched over Denmark, Germany north of the river Elbe, northern parts of Poland and Belarus, and covered the northwestern Russian Plain from Belarus to the Arkhangelsk Region (Svendsen et al., 2004; Ehlers et al., 2013a). No ice-dammed lakes during the LGM were observed along the northern glacier rim of the Russian Lowland, contrary to the situation at earlier glaciations (Astakhov, 2006, 2013; Ehlers et al., 2013a, b).
Greater mountain glacial complexes occurred in the Alps (Ehlers et al., 2013a) and in the Central Asian high mountains (Owen, 2013) including the Altai and neighbouring mountain systems (Lehmkuhl et al., 2011). Limited and local mountain glaciers are known from the Pyrenees, Carpathians and Caucasus.

Permafrost and loess deposition reached a maximum during Late Pleistocene. The Eurasian loess belt stretches from western Europe across the East European Plain, central and south Siberia to the central Chinese loess-plateau. The Siberian high-resolution loess-palaeosol sequences represent a significant data source of Quaternary climatic history in northern Asia. Palaeoenvironmental multiproxy data (sedimentary, pedogenic and biotic) from the series of palaeosols separated by loess beds provide evidence for strongly fluctuating climates and landscape development during the Late Pleistocene, and for changes in the vegetation zones during interglacial/interstadial and stadial stages (Chlachula, 2003; Rutter et al., 2003).

Correlation of Late Pleistocene chronostratigraphical terminology for eastern Europe and Russia is presented in Table 7. Major events during the Late Pleistocene in northern Eurasia are summarized in Table 8. The listed essentials are based mainly on Golubeva (1979), Frenzel (1992), Grichuk (1992), Akhmetiev et al. (1999), Arkhipov et al. (1999), Fradkina et al. (1999a, b), Korotky et al. (1999), Velichko et al. (1999), Chlachula (2001a, b, 2010), Shichi et al. (2007), Tarasov et al. (2009), Felauer et al. (2012), and Yanina et al. (2018).

During the last interglacial (MIS 5e), steppes were only found in southeastern Europe, near the Black and Caspian seas. In western Siberia, Kazakhstan and Central Asia (Mongolia) the southern boundary of this vegetation lay far to the South of its present position (Fig. 1). In northern Eurasia, main types of vegetation during the maximum cooling of the last glacial (MIS 2) were a mixture of cryophytic steppe and tundra communities, often summarized as "periglacial tundra", "tundra steppes" and "periglacial steppe". The more thermophilic loesssteppe and herb-steppe spread over interior regions of the Middle East and Central Asia. In northern Mongolia, grass-herb and sagebrush steppe formations dominated, while larch, birch and pine grew on the mountain slopes. Boreal forests were limited to mountainous areas in Europe and Asia, whereas broadleaved forests of nemoral type were restricted to southern Europe, Asia Minor, southern Urals and parts of the Altai. Also in China, Korea, Manchuria and central Japan (Fig. 2). 
Late Pleistocene chronostratigraphic correlation for eastern Europe and Russia

\begin{tabular}{|c|c|c|c|}
\hline $\begin{array}{c}\text { Late Pleistocene } \\
\text { (MIS) }\end{array}$ & East European Plain & Siberia & Russian Far East \\
\hline $\begin{array}{c}\text { ca. 25-10 ka } \\
\text { (MIS 2, glaciation) }\end{array}$ & Late Valdai & Sartan & Partisanian \\
\hline $\begin{array}{c}\text { ca. } \mathbf{6 0}-\mathbf{2 5} \text { ka } \\
\text { (MIS 3, interstadial) }\end{array}$ & $\begin{array}{c}\text { Mid-Valdai } \\
\text { (Dunalvo or Briansk } \\
\text { interval) }\end{array}$ & Karginsky & Chernoruchinsky \\
\hline $\begin{array}{c}\text { ca. 75-60 ka } \\
\text { (MIS 4, glaciation) }\end{array}$ & Early Valdai & $\begin{array}{c}\text { Zyranka } \\
\text { (Yermakovo in W Siberia, } \\
\text { Muruktinsky in E Siberia) }\end{array}$ & Lazovian \\
\hline $\begin{array}{c}\text { ca. 115-75 ka } \\
\text { (MIS 5a-d, }\end{array}$ & $\begin{array}{c}\text { Final stages of } \\
\text { Interglacial } \\
\text { (Mikulino) }\end{array}$ & $\begin{array}{c}\text { Final stages of Interglacial } \\
\text { (Kazantsevo) }\end{array}$ & $\begin{array}{c}\text { Final stages of Interglacial } \\
\text { (Nakhodkinsky) }\end{array}$ \\
\hline $\begin{array}{c}\text { ca. 130-115 ka } \\
\text { (MIS 5e, interglacial) }\end{array}$ & $\begin{array}{c}\text { Mikulino } \\
\text { (Interglacial Optimum) }\end{array}$ & $\begin{array}{c}\text { Kazantsevo } \\
\text { (Interglacial Optimum) }\end{array}$ & $\begin{array}{c}\text { Nakhodkinsky } \\
\text { (Interglacial Optimum) }\end{array}$ \\
\hline
\end{tabular}

Notes: Abbreviations: MIS - Marine Isotope stages. For references see text.

\subsection{Late Pleistocene vegetation}

\subsubsection{Use of terms}

Nomenclature/terminology to describe vegetation and environments during the last ice age is extremely confusing. Terms like "tundra-steppe", "steppe-tundra", "periglacial vegetation", "periglacial cold steppe", "ice age steppe", "arctic steppe", "loess steppe", "mammoth steppe", and others, have to be discussed and clarified.

The terminological confusion has several roots. Some terms are synonymous as, for instance, tundra-steppe (preferred in Russian literature) and steppe-tundra (preferred in English literature). The main problem, however, is that the terms were never unequivocally defined. Yurtsev (last in 2001), for instance, used the term tundra-steppe for main vegetation types (ecosystems) and for landscapes (see below). In the "Atlas of Palaeoclimates and Environments of the Northern Hemisphere" Frenzel et al. (1992) attempted to avoid confusion of concepts and used different names for describing/characterization of vegetation, ecosystems (main vegetation), and landscape types of the LGM. However, still there is overlapping terminology as can be seen from Table 9. The term tundra-steppe is applied by Frenzel (1992) to characterize vegetation and by Velichko and Isayeva (1992) to name a landscape type, the term periglacial steppe - to name a main vegetation type (ecosystem) (Grichuk, 1992) as well as a landscape type (Velichko, Isayeva, 1992).

Guthrie (1982) introduced the term "Mammoth steppe" to a wider readership, and this new neologism is often used in recent literature. It indicates a
Late Pleistocene "low sward of herbaceous plants, with grasses, sedges, forbs and sages predominating" (Guthrie, 2001). This kind of vegetation was the grazing area of a megafauna dominated by the key grazers bison (Bison spec.), horse (Equus spec.) and woolly mammoth (Mammuthus primigenius) (Guthrie, 2001). This Mammoth fauna complex was widespread over vast areas of Eurasia and extended into North America during the last glacial (MIS 5dMIS 2) (see Table 8). For the Eurasian branch (the Palaearctic) of the Mammoth fauna complex, two species became eponymous, $M$. primigenius, the woolly mammoth, and Coelodonta antiquitatis, the woolly rhinoceros. The distribution of the Mammuthus-Coelodonta faunal complex in Eurasia (Baryshnikov, Markova, 1992; Kahlke, 2014) coincides with the extent of the permafrost landscapes during the LGM (Periglacial Tundra steppes and Periglacial steppes, Table 9). It is an open question whether the introduction of the new/additional term "Mammoth steppe" was/is necessary or not. One may ask whether the "Mammoth tundra-steppe assemblage" concept used preferably in Russian literature (Baryshnikov, Markova, 1992, and literature cited therein; Table 8) would not mean the same, and Walker et al. (2001) used "Mammoth steppe" and "steppe tundra" synonymously. In a narrow sense, however, mammoth steppe often means a Late Pleistocene palaeoenvironment of Arctic steppe-like vegetation with dominance of graminoids (see below).

The terminological confusion characterizes the prevalent situation and attempts to change it appear to be lost time. In this review, we prefer the termi- 
nology 'periglacial tundra' and 'periglacial steppe' as outlined in Table 9.

\subsubsection{Tundra-steppe concept}

Scientist now agree that climate over much of northern Eurasia during the Pleistocene glacial maxima was not the same as today's arctic climate.
It was extremely continental and arid with winters colder and summers warmer than at present. This climate has no modern equivalents. Northern Eurasia was covered by a grassy vegetation characterized by both, tundra and steppe elements, whereas today a mesophytic tundra is the main vegetation of the subarctic-arctic climate zone. It is a moot point

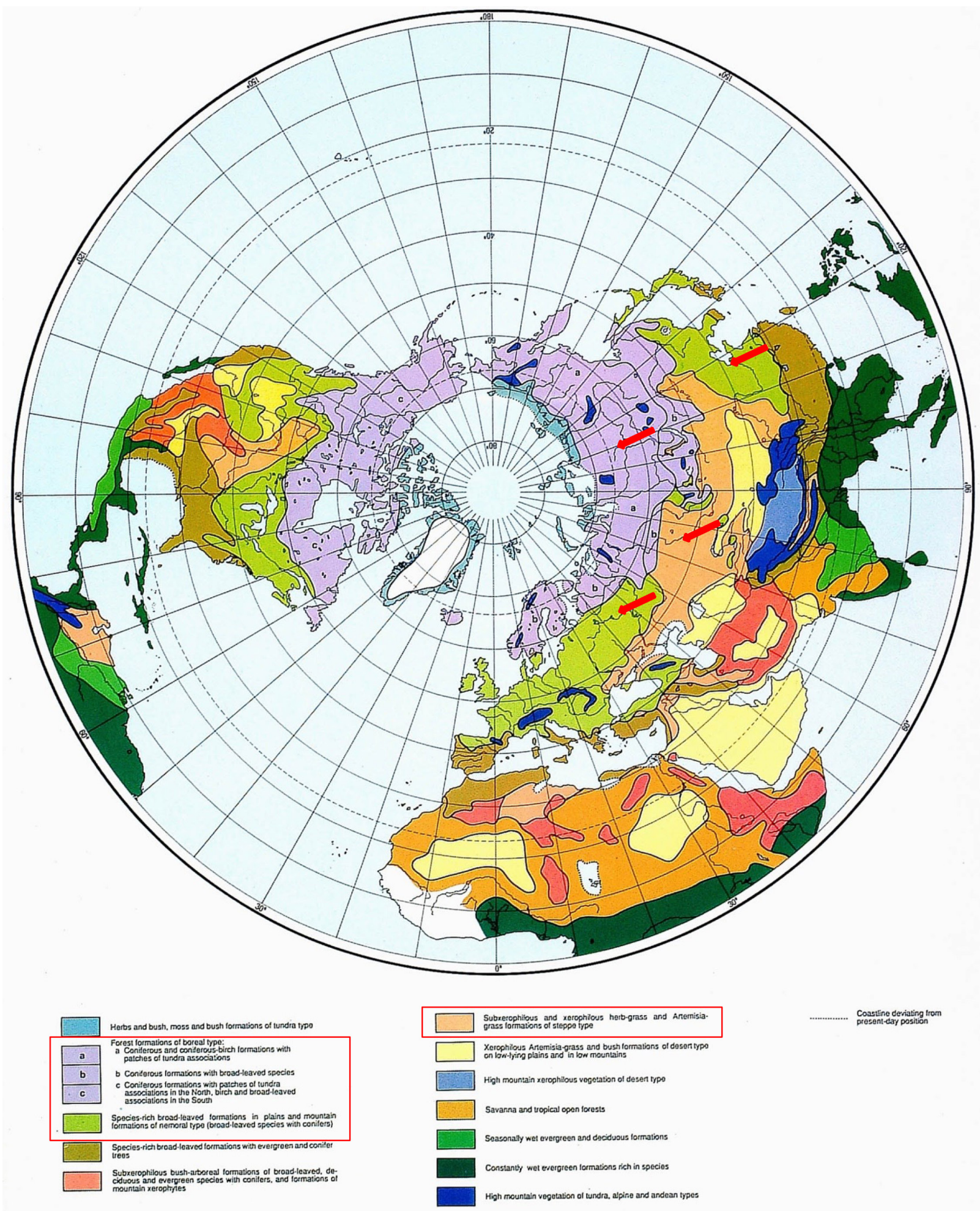

Fig. 1. Last Interglacial Vegetation of the Northern Hemisphere. Modified from: V. P. Grichuk (1992) in "Atlas of Palaeoclimates and Palaeoenvironments of the Northern Hemisphere". 
whether the LGM vegetation types have any sort of present-day analogue as argued, for instance, by Walker et al. (2001) and Chytrý et al. (2018).

Evidence for a cold and arid steppe like vegetation was already provided at the end of the $19^{\text {th }}$ and early $20^{\text {th }}$ centuries when scientists studied loess deposition, vertebrate faunas and pollen spectra from LGM deposits. Nehring (1890) discovered fossils of steppe mammals in glacial loess deposits in middle Europe. He also provided first evidence for a fauna nowadays characteristic for the northern Eurasian tundra, which preceded this steppe fauna. Later, Büdel $(1949 b, 1951)$ indicated a general two-stage climate succession during glacial cycles:

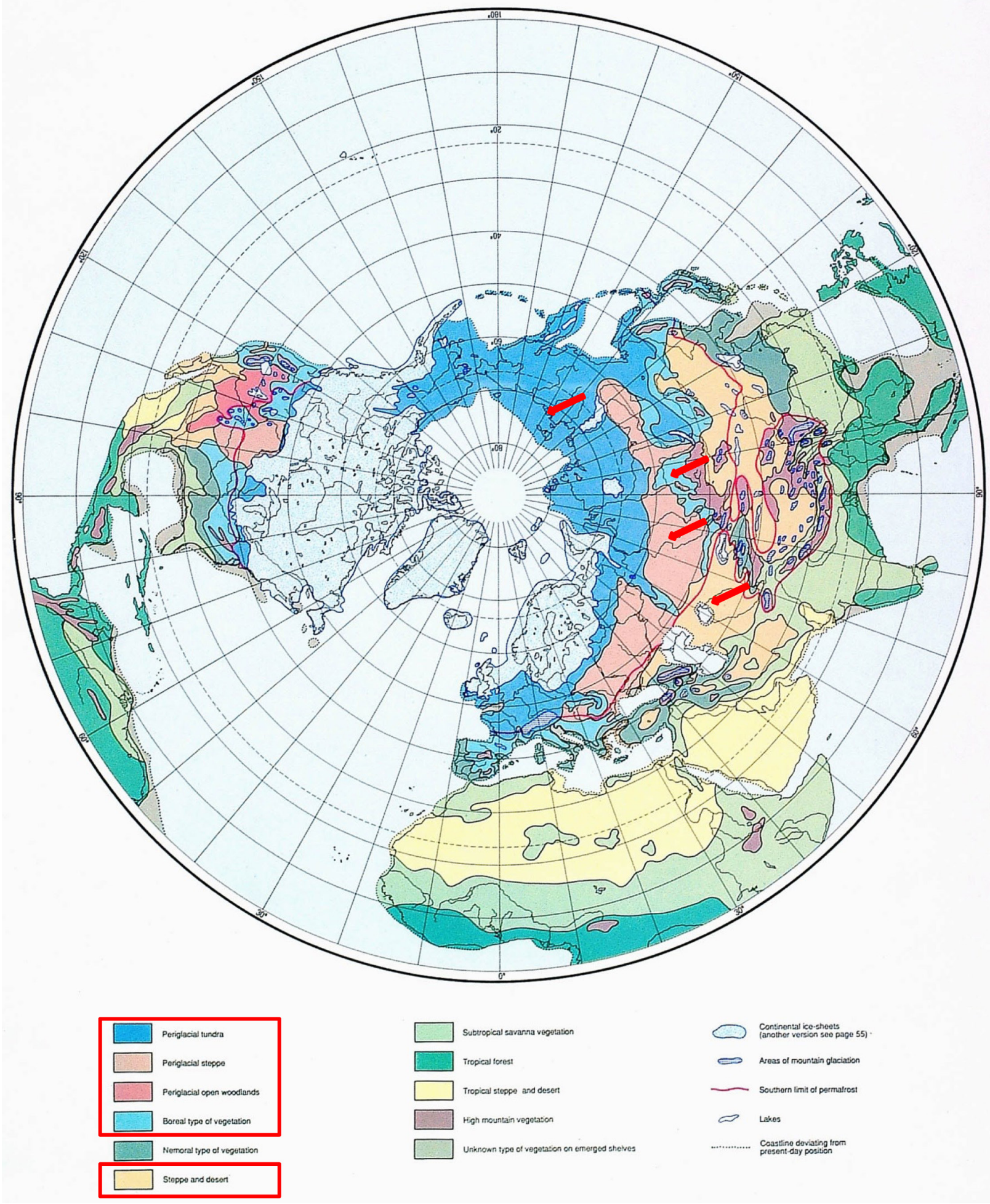

Fig. 2. Main Types of Vegetation (Ecosystems) during maximum cooling of the Last Glaciation, Modified from: V. P. Grichuk (1992) in "Atlas of Palaeoclimates and Palaeoenvironments of the Northern Hemisphere". 
a period of relatively cold but particularly moist conditions allowing the formation of the inland ice sheets, followed by a period of very cold and very dry conditions. In other words: a shift from an early glacial suboceanic/oceanic climate with tundra-like vegetation to a late glacial extremely continental climate with steppe-like vegetation. Strong winds and substantial loess deposition characterize this latter period.

An important line is the $10{ }^{\circ} \mathrm{C}$-July-isotherm since the polar tree and forest line run approximately parallel to this line, and it marks the commonly accepted southern boundary of the tundra. Büdel (1949a) reconstructed a $10.5{ }^{\circ} \mathrm{C}$-July-isotherm for the last glacial and argued that the course of this line marks the most northern tree line during the LGM.
The $10.5{ }^{\circ} \mathrm{C}$-July-isotherm runs from southern France across central Europe and the east European lowland to the middle Ural Mts. It crossed the great European loess wedge, which stretches from eastern Europe to Brittany. Büdel called the loess region north of the polar tree line "Lösstundra" (loess tundra) and south of it "Lössteppe" (loess steppe). Despite the sparse tree growth within the loess steppe and its rich grass and herb vegetation cover compared to the loess tundra, vegetation character of the loess tundra, and loess steppe was very similar and the climate-morphological aspects of the landscapes were identical. The loess tundra was as much steppe as tundra (Büdel, 1949a, b), a view, which comes close to the tundra-steppe concept outlined below.

Table 8

Major events during the Late Pleistocene

\begin{tabular}{|c|c|}
\hline $\begin{array}{l}\text { Late Pleistocene } \\
\text { (MIS; stages from } \\
\text { west to east) }\end{array}$ & Climate/landscape and biotic environments \\
\hline $\begin{array}{c}\text { Last Glaciation } \\
\text { (MIS 2; Late Valdai, } \\
\text { Sartan, Partisanian) }\end{array}$ & $\begin{array}{l}\text { Severity of cryo-arid conditions reached a maximum; during 14-13 ka degradation } \\
\text { of glacial systems, permafrost moved to the northeast. Phenomenon of hyperzonality } \\
\text { (super zones). } \\
\text { Periglacial tundra: stretching from western Europe north of the Alps over northern } \\
\text { East European Plain, Urals, northern Siberia, Beringia to northern Far East. Periglacial } \\
\text { steppe: over most of Eastern Europe, west Siberian lowlands, northern Kazakhstan } \\
\text { to central Yakutia. Boreal forests: limited to Urals, some mountains in central and } \\
\text { eastern Siberia, Mongolia, Manchuria. Nemoral forests: in mountains of Central Asia, } \\
\text { southern Urals, Altai, central and eastern China. Steppe and desert: Central Asia and } \\
\text { northern China (see Fig. 2). }\end{array}$ \\
\hline $\begin{array}{l}\text { Last interstadial } \\
\text { (MIS 3; Mid- } \\
\text { Valdai, Karginsky, } \\
\text { Chernoruchinsky) }\end{array}$ & $\begin{array}{l}\text { Coolings and warmings. Considerable degradation of ice sheets, early phases close to } \\
\text { interglacial conditions. } \\
\text { First phase of Khvalynian Caspian Sea transgression. } \\
\text { East European Plain: taiga forests during warmings and periglacial forest-steppe and } \\
\text { forest-tundra during coolings. West Siberia: boreal cold-temperate, northern taiga } \\
\text { forests. Northeastern Asia: expansion of trees and shrubs to the north. Central Asia: } \\
\text { moist and cool climate prevailed, humid and dry steppes. }\end{array}$ \\
\hline $\begin{array}{l}\text { Penultimate } \\
\text { Glaciation } \\
\text { (MIS 4; Early Valdai, } \\
\text { Zyranka, Lazovian) }\end{array}$ & $\begin{array}{l}\text { Cold-humid climate. Scandinavian ice sheet smaller than during LGM, in east Siberia } \\
\text { ice sheet larger than during LGM. } \\
\text { East European Plain: northern taiga, meadow steppe, permafrost in the north and } \\
\text { middle part. West Siberia: middle and north taiga, forest tundra. Northeastern Asia: } \\
\text { meadow steppe. Central Asia: predominantly steppe and desert-steppe. }\end{array}$ \\
\hline $\begin{array}{l}\text { Last Interglacial } \\
\text { Optimum } \\
\text { (MIS 5e; Mikulino, } \\
\text { Kazantsevo, } \\
\text { Nakhodkinsky) }\end{array}$ & $\begin{array}{l}\text { Winter and summer temperatures above today's, permafrost in the plains only along } \\
\text { northern ocean coast. } \\
\text { Late Khazarian Caspian Sea transgression. } \\
\text { East European Plain: main part with nemoral forests, to the north boreal coniferous } \\
\text { forests, absence of tundra; steppes only near Black and Caspian Seas. Siberia: boreal } \\
\text { forests most important, in W Siberia no tundra, further east tundra vegetation along } \\
\text { northern coast; in southern W Siberia forest-steppe. Kazakhstan and Mongolia: } \\
\text { forest-steppe and steppes, extending far south to latitude } 40^{\circ} \text {, forests in the mountains. } \\
\text { Southern Far East: predominance of polydominant nemoral forests with Manchurian } \\
\text { flora elements (see Fig. 1). }\end{array}$ \\
\hline
\end{tabular}

For references see text. 


\section{Terminology of palaeoenvironments of the Eurasian permafrost zone during Last Glacial Maximum (LGM)}

\begin{tabular}{|c|c|c|c|c|}
\hline $\begin{array}{c}\text { From northern } \\
\text { ice/coastlines to } \\
\text { southern limit } \\
\text { of permafrost } \\
\text { (ca. } 40^{\circ} \text { to } 50^{\circ} \mathrm{N} \\
\text { latitude) } \\
\end{array}$ & $\begin{array}{c}\text { Vegetation } \\
\text { (Frenzel, 1992) }\end{array}$ & $\begin{array}{c}\text { Main types } \\
\text { of vegetation } \\
\text { (ecosystems) } \\
\text { (Grichuk, } \\
\text { 1992) }\end{array}$ & $\begin{array}{l}\text { Landscape types } \\
\text { (Velichko, } \\
\text { Isayeva, 1992) }\end{array}$ & $\begin{array}{l}\text { Main mammal } \\
\text { assemblages } \\
\text { (Baryshnikov, } \\
\text { Markova, 1992) }\end{array}$ \\
\hline $\begin{array}{l}\text { Northern part } \\
\text { south to ca. } 60^{\circ} \mathrm{N} \\
\text { latitude }\end{array}$ & $\begin{array}{l}\text { - Tundra-like in W } \\
\text { and Central Europe } \\
\text { - Mixture of steppe } \\
\text { and tundra in E } \\
\text { Europe and W Siberia } \\
\text { - Tundra-steppe in NE } \\
\text { Siberia } \\
\end{array}$ & $\begin{array}{l}\text { Periglacial } \\
\text { tundra (in } \\
\text { eastern Asia } \\
\text { to ca. } 50^{\circ} \mathrm{N} \text { ) }\end{array}$ & Tundra steppes & $\begin{array}{l}\text { Mammoth tundra-steppe } \\
\text { assemblage, arctic sub- } \\
\text { assemblage }\end{array}$ \\
\hline $\begin{array}{c}\text { Southern part } \\
\text { from ca. } 60^{\circ} \mathrm{N} \text { to } \\
\text { ca. } 50^{\circ} \mathrm{N} \text { latitude, } \\
\text { in Mongolia to } \\
\text { ca. } 40^{\circ}\end{array}$ & $\begin{array}{c}\text { - Steppe from E } \\
\text { Europe to W Siberia } \\
\text { and Kazakhstan } \\
\text { - Loess-steppe } \\
\text { from Kazakhstan to } \\
\text { Russian Far East } \\
\text { - Herb-steppe in } \\
\text { Mongolia and NE } \\
\text { China }\end{array}$ & $\begin{array}{l}\text { Periglacial } \\
\text { steppe; steppe } \\
\text { and desert in } \\
\text { Mongolia }\end{array}$ & $\begin{array}{c}\text { Periglacial } \\
\text { steppes; deserts } \\
\text { and high } \\
\text { mountain steppes } \\
\text { in Mongolia; } \\
\text { open forests in } \\
\text { Amur basin and } \\
\text { Manchuria }\end{array}$ & $\begin{array}{l}\text { Mammoth tundra-steppe } \\
\text { assemblage, boreal } \\
\text { sub-assemblage; south } \\
\text { to it from west to east: } \\
\text { Pontian-Kazakhstan } \\
\text { steppe, Mongolian } \\
\text { desert-steppe and Japan- } \\
\text { Chinese forest-steppe } \\
\text { assemblages }\end{array}$ \\
\hline
\end{tabular}

In the following decades, Russian botanists and palaeobotanists provided evidence for 'periglacial' vegetation during the LGM, which resembled tundra, bog, woodland, and steppe. This 'periglacial' area comprises not only landscapes in glacial proximity but also vast areas many hundreds of kilometres away from glacial proximity; areas, which still exhibit landscape features similar to those of the landscapes in glacial proximity. This growing knowledge of the late Pleistocene vegetation of northern Eurasia finally resulted in the "Tundra-Steppe" concept (in English literature mostly "Steppe Tundra"). For a short history of the tundra-steppe concept, see Hibbert (1982). Tundra-steppe means either a certain type of plant communities with codominance of both, steppe and tundra species, or a type of (palaeo) landscape, codominated by both steppe and tundra. As such, the tundra-steppe is a 'hybrid' ecotonal community between steppe and tundra (Yurtsev, 1974, 1981, 2001). Throughout the Pleistocene the mesic tundra stages alternated many times with the tundra-steppe. A specific feature of the cold hypo-arid epochs of the Pleistocene was the expansion of cryophytic steppes on the northern plains, dominated by steppe xerophytes and arctic-alpine cryoxerophytes, as the zonal types of communities and ecosystems on the driest habitats, whereas mesic and hygric tundras occupied subordinated positions beyond watersheds (Yurtsev, 2001).

The plant cover of the Pleistocene tundra-steppe landscapes was not homogeneous throughout its distribution area. It exhibited the same kind of regional differentiation seen in the modern steppe regions of the interior regions of Eurasia and North America (Yurtsev, 2001). This is clearly mirrored, for instance, in the characterization of the vegetation by Frenzel (1992) and main types of vegetation (ecosystems) in Eurasia by Grichuk (1992; and Fig. 2). Main formations of the periglacial tundra vegetation and tundra-steppe landscapes (Table 9) in western Siberia included subarctic meadows, low bush tundra and open birch woodlands in the plains, and montane bush tundra in the highlands. In eastern Europe, the tundra and cryophytic steppe communities predominated in combination with open woodlands of larch and birch. In northeastern Siberia, polar deserts and montane tundra with xerophytic steppe associations were widespread. In the periglacial steppe vegetation (Table 9), meadow steppes with larch, pine and birch forests predominated.

The modern flora of the Arctic and Subarctic contains a variety of 'tundra-steppe' elements and 
may allow reconstructing the Pleistocene tundrasteppe landscapes (Yurtsev, 1974, 1981). The steppe associations of northeastern Asia (meadow steppe, steppe proper, and petrophytic steppe) comprise many relic species (Yurtsev, 1978). The relict steppe vegetation in Yakutia occurs at south-exposed, welldrained, dry and warm extrazonal sites within the taiga zone (Yurtsev, 1982, 2001). The main ecological factor determining the distribution of steppe and its niche in the tundra and taiga landscapes is soil aridity (Yurtsev, 2001). The maximum diversity of northern relic steppes and steppe plants within the Arctic has been recorded in the Beringian sector (Yurtsev, 1981, 1986).

Guthrie (2001) argues that the diverse Late Pleistocene grazing megafauna could have been supported only by arid, grass- and forb-dominated ecosystems (his "Mammoth steppe"). Based on palaeodiet studies and on the combined presence of grazing specialists but absence of browsing specialists in the fossil assemblages, he further concluded that the Mammoth fauna used grasses as their dietary sample. Hence, he argued for dominance of grassland type of environment during full Glacial, an overemphasized view that was never held by Russian and other scientists (see Table 9; Yurtsev, 2001). Plant macrofossils from a permafrost sequence in the Lena delta prove that during the last cold-stage arctic species coexisted with aquatic, littoral, meadow and steppe taxa, and the reconstructed vegetation composition is similar to modern vegetation mosaics in northeast Siberian relict steppe areas (Kienast et al., 2005). Productive meadow and steppe communities played an important role in the Siberian arctic vegetation during the late Pleistocene and could have served as food resources for large populations of herbivores as already argued before by many scientists (e. g., Yurtsev, 2001). This might solve the long debated "productivity paradox", the discrepancy between the cold and dry palaeoclimate and its supposed sparse vegetation and the highly diverse herbivorous fossil megafauna. Recently, Willerslev et al. (2014) presented a large-scale ancient DNA metabarcoding study of circumpolar plant diversity, representing the last $50 \mathrm{kyr}$ of Arctic vegetation history. They provide evidence that during the LGM in the unglaciated Arctic and adjacent regions a steppetundra consisted dominated by forbs. Their analyses also indicated that, in contrast to Guthrie's (2001) findings, the megafaunal diet comprised both, graminoids and forbs. Thus, recent plant macrofossil and ancient DNA studies question the predominance of a graminoid-dominated "Mammoth steppe".

\section{Climate and landscape history in the Holocene}

\subsection{Holocene classification systems}

The Holocene Series/Epoch is the latest interval of geologic time (post-Glacial time) and the most recent stratigraphic unit. The Pleistocene - Holocene boundary and thus the beginning of the Holocene Epoch has been selected at several different times in the past. Only recently, it has been formally defined and dated approximately $11,700+/-100$ cal. years BP (before AD 2000) and accepted by the ICS (International Commission on Stratigraphy) (Walker et al., 2009). Climatically, this boundary coincides with the end of the Younger Dryas cold sub-stage of the last glacial period.

Many attempts to subdivide the Holocene have been undertaken but are inconclusive at a global or at least at a hemispherical scale. Well-known is the Blytt-Sernander classification. Based on climatic fluctuations, the Holocene is subdivided into the five chronozones (Fig. 3): Preboreal (cool/dry) - Boreal (warm/dry) - Atlantic (warm/wet) - Subboreal (warm/dry) - Subatlantic (cool/wet). The scheme was originally defined for northern Europe (Mangerud et al., 1974) but is widely applied to whole Eurasia. Regional pollen stratigraphies are often correlated with the Blytt-Sernander framework, and it has been closely checked by radiocarbon dating, establishing a very useful standard.

Walker et al. (2012) proposed a formal subdivision of the Holocene into 'Early', 'Middle' and 'Late' Holocene taking up the widespread but variable use of these terms in the relevant literature. These proposals have been accepted by the International Union of Geological Sciences in 2018. The boundary between Early and Middle Holocene is set around 8200 years BP, and the Middle - Late Holocene boundary - around 4200 BP (see Fig. 3). The rational for choosing these date lines are as follows. The " $8.2 \mathrm{ka}$ event" reflects abrupt cooling of near global significance marked by shifts in ${ }^{18} \mathrm{O} /{ }^{16} \mathrm{O}$ and $\mathrm{D} / \mathrm{H}$ and numerous proxy climate records. The $8.2 \mathrm{ka}$ event, which may have even caused local resurgence of ice cover, was just a short-lived cold, dry interval with no long-term climatic consequences. Climate after the $8.2 \mathrm{ka}$ event was the same as before (Roberts, 2014). The " 4.2 ka event" marks a widespread predominantly mid- and low-latitude aridification reflected in many climatic proxy records worldwide but it is not clear if it was synchronous in different parts of the world. For details and discussions see Walker et al. (2012). 
The beginning of the Holocene corresponds with the beginning of the Mesolithic age in most of Europe. During the Holocene climatic optimum (Atlantic zone, see Fig. 3), Neolithic humans spread across Eurasia into northernmost regions.

\subsection{Holocene climate history}

At the beginning of the Holocene, temperature increased considerably and reached a maximum when mean annual temperature was above that of today marking the start of a warm interval. Many climatic proxy data reflect this warming trend, which was interrupted by short warm/cold cycles. This interval is called the Holocene Climate Optimum or Hypsithermal (also Altithermal and Xerothermic) and lasted from about 9,000 to 5,000 cal years BP (Atlantic zone in the middle Holocene, Fig. 3).
However, statements about duration and time of the Holocene Climate Optimum vary greatly depending on the geographical region, on the availability of proxy data and on methods of data evaluation. Warming was probably not uniform across the planet. Nearly everywhere on the Northern Hemisphere, mean annual temperature was about $0.5-1.0^{\circ} \mathrm{C}$ above present, but depended on geographical latitude. Positive deviations from present values were higher in polar and subpolar regions but there was cooling in tropical and subtropical regions. Middle Holocene deviations of temperatures and precipitation from present-day values are shown in maps in Frenzel et al. (1992). After this warm period a gradual temperature decline followed until about two millennia ago.

(c)

(b)

\begin{tabular}{|c|c|c|c|c|c|}
\hline \multicolumn{3}{|c|}{ Late Stone Age } & \multicolumn{2}{c|}{ Bronze Age } & Iron Age $\begin{array}{l}\text { Middle and } \\
\text { Modern Age }\end{array}$ \\
\hline Preboreal & Boreal & Atlantic & \multicolumn{2}{c|}{ Subboreal } & Subatlantic \\
\hline Early Holocene & Middle Holocene & \multicolumn{3}{|c|}{ Late Holocene } \\
\hline
\end{tabular}

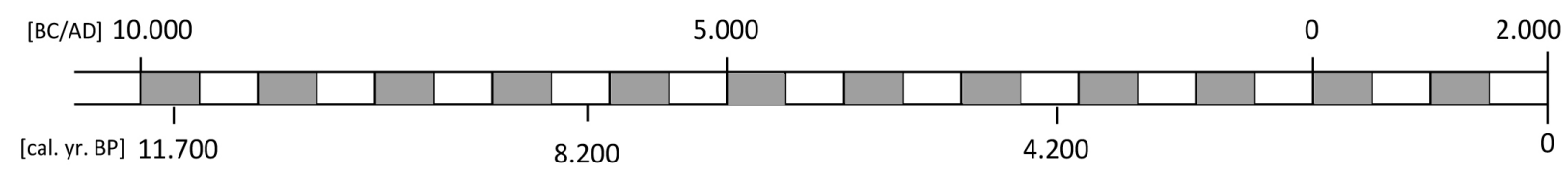

Fig. 3. Holocene temporal range, subdivisions, chronozones and periodization of human history. Abbreviations: cal. yr. BP Calibrated years before present. "Present" refers to the year 2000. BC/AD Date description before Christ / after Christ (= Anno Domini): (a) Formal subdivision of the Holocene according to Walker et al. (2012). (b) Chronozones based on climatic fluctuations, following Mangerud et al. (1974). Radiocarbon years are converted to calendar ages. (c) Periodization of human history according to the Three-Aged-System. The Late Stone Age includes the Mesolithicum and the Neolithicum.

\subsection{Megafaunal extinction at the Pleistocene- Holocene transition}

During the late Pleistocene and early Holocene, about $75 \%$ of the larger mammals became extinct including mammoths and mastodonts. Hypotheses for the late Pleistocene/early Holocene megafauna's extinction involve climate and habitat changes, but many authors also assign humans a role for the megafaunal extinction (Lister, Stuart, 2008; Campos et al., 2010; McDonald et al., 2012; Prescott et al., 2012).

9.3.1 Causes for the megafaunal extinction at the Pleistocene-Holocene transition

The debate over the causes of the worldwide late Quaternary extinction of the large herbivores (mostly defined as taxa $\geq 45 \mathrm{~kg}$ in body weight) and especially of the megaherbivores $(\geq 1000 \mathrm{~kg}$ in body weight) has continued for over 200 years. Climate change and spread of modern humans and related effects such as hunting ('overkill' hypothesis; Martin, 1984; Owen-Smith, 1987) and/ or habitat modification and fragmentation are seen as primary drivers, but it remains controversial whether human colonisation or climatic change were more important drivers with hardly any extinction being unambiguously attributable to either. A diversity of extinction patterns has been observed on different continents. Barnosky et al. (2004) assumed that humans contributed to the extinction on some continents but were not solely responsible for the extinction everywhere. For the Northern Hemisphere, for instance, they suggest the intersection of human impacts with pronounced 
climatic change drove the timing and geography of the extinction. This is in line with the scenario put forward by Zimov et al. (2012) who argue that Holocene warming became fatal for the mammoth ecosystem not because of climate change per se, but because with warming humans penetrated to the North. They caused a decline of herbivores, thereby decreasing pastures with the eventual extinction of the megafauna. Sandom et al. (2014b) provided strong support for modern humans as the primary driver of the worldwide megafaunal losses with a weak Eurasia-specific link to climate change. Analyses of Bartlett et al. (2016) also identify human colonisation as the most important driving factor on a global scale but assume that climate factors were also important. The low extinction rate found in the fossil record of mainland Asia, however, could not be explained. A potential strong role of rapid climate changes associated with interstadial warming events is emphasized by Cooper et al. (2015) for the Northern Hemisphere, and RabanusWallace et al. (2017) suggest that moisture-driven environmental changes played an important part in the late Quaternary megafaunal extinctions in Europe, Siberia and the Americas.

It thus appears that the causes of the worldwide megafaunal herbivore extinction at the PleistoceneHolocene transition are still not fully understood. Although great progress has been made, interplay of human influence and climate change, role of environmental change, diversity in timing, regional climate and geography remain complicated problems, and the late Quaternary extinction of the large herbivores continues to be disputed.

\subsubsection{Consequences of megafaunal extinctions}

The ecosystem consequences of the herbivore megafauna loss are not well understood. The 'wood-pasture' hypothesis suggests that - before agriculture - large gracing herbivores support a dynamic mosaic of forests and open grassland within the temperate forest biome at the landscape scale. Large herbivores thought to be important 'ecosystem engineers' in temperate forest biomes. The contrasting position suggests closed forests with relatively small open areas caused locally by large herbivores. There seems to be increasing evidence for the ecosystem effects of the late Pleistocene and early Holocene megafaunal losses around the world. Decline of large herbivores induces major alterations in landscape structure and ecosystem function (Sandom et al., 2014a, b; Bakker et al., 2016; Malhi et al., 2016, and literature cited therein).

\subsection{Reconstructions of Holocene environments}

Reconstructions of past climates and vegetation types heavily depend on the quality and quantity of proxy data, which include biological, geophysical and geochemical as well as geological and geomorphological data. The reconstructions also depend on dated records and on the methods employed for data evaluation. Great progress has been achieved in these fields in the last decades. Pollen analyses have significantly contributed to the knowledge about late Quaternary vegetation, and the "biomization" approach introduced by Prentice et al. (1996) has become a powerful tool for vegetation reconstruction from late Quaternary pollen data of Eurasia. This is especially true for the Holocene. The Biomization Method (= biome reconstruction) is based on an assignment of pollen taxa to plant functional types (PFTs) on the basis of the known biology of the plants. The PFTs are then assigned to major vegetation types (biomes) on the basis of their closest modern pollen analogues ("best-modernanalogue", BMA). The BMA is orientated towards modern surface-pollen data sets taking into account present-day ecology, bioclimatic tolerance and geographical distribution of pollen-producing plants. The method then attributes the average climate associated with these "modern analogues" to the fossil pollen (Bartlein et al., 2011). Results obtained both with traditional (qualitative) approaches and the quantitative method of biomization mostly show good compatibility. However, biomization allows for improved quantification of past climate parameters and increasing resolution of vegetation analyses in space and time.

Main sources for Holocene vegetation reconstructions are at present pollen diagrams, plant macrofossils and dated paleontological and archaeological remains. Over the past several decades the number of published late-Quaternary pollen records from northern Asia increased rapidly and enables continental-scale vegetation and climate reconstructions (Tarasov et al., 2007; Binney et al., 2017). It would appear that the Holocene is the best studied of all chronostratigraphical series.

\subsection{Holocene climate and vegetation of the Eurasian steppe belt \\ 9.5.1 General features}

In northern Eurasia, Holocene temperature fluctuations decreased in a range eastwards, primarily because of a west to east weakening influence of the westerly air masses and strengthening of continental climate. Climatically triggered vegetation zone 
shifts between the tundra, forest-tundra and forest decreased also from West to East, whereas the boundary between forest and steppe remained rather constant over whole northern Eurasia. Only during the Holocene climatic optimum that boundary moved slightly to the North due to an increase of the forest-steppe zone. In general, climate fluctuations were more pronounced in eastern Europe than in Siberia, but mid-Holocene warming characterizes all northern Eurasia although with regional differences (Velichko et al., 1997, 2002; Velichko, 1999).

There have been major shifts in the distribution of animals and plants during the Holocene. Many Pleistocene environments, in which plants and animals coexisted in the cooler climates of the late Pleistocene, were destroyed or fragmented. Relict areas are separated today by hundreds or thousands of kilometres or have been isolated in higher altitudinal 'islands'.

At the end of the Pleistocene, a tremendous increase in rainfall occurred in the mid-latitudes and in the tropics. They caused a vast proliferation of pluvial lakes. In the high- to mid-latitudes, tundra passed to birch forests in the early Holocene. Great moisture in the Polar Regions has caused the disappearance of the tundra-steppe. During the warm period of the middle Holocene, a progressive change to pine forests and then oak, beech or mixed forests can be observed in Eurasia. In the mid-latitude continental interior, hot summers prevailed but winters became colder and drier, and steppe expanded. Many lake levels showed a drop.

The full-glacial landscape of northern Eurasia was largely treeless (Tarasov et al., 2000b; Bigelow et al., 2003; Binney et al., 2017), dominated by herbrich biomes. Grasses, sedges and forbs are dominant until $15 \mathrm{kyr}$ cal BP (Binney et al., 2017). Between 15 and $8 \mathrm{kyr}$, herb-dominated biomes are reduced and forest biomes spread across northern Eurasia. However, trees apparently were not completely absent during the LGM. Pollen and macrofossil data demonstrate the existence of woody taxa including Picea, Larix, Pinus, Alnus and Betula in the periglacial zone across the whole Eurasian region, and it is likely that refugial populations persisted under the cool and dry conditions of the full-glacial (Frenzel, 1968, 1979, 1992; Grichuk, 1992; Velichko, Isayeva, 1992; Tarasov et al., 2007; Binney et al., 2009, 2017).

With a shift to warmer and moister Holocene climates, treeless vegetation was replaced by boreal or temperate forests over much of the region and wetland extent increased (Andreev, Tarasov, 2013; Bin- ney et al., 2017). The Pleistocene tundra-steppe hyperzone dispersed, and the Altai Mountains became an important climate boundary for the environmental Holocene history of the mid-latitude belt in Asia. In the second half of the Holocene, wetter climate conditions prevailed west and north of the Altai Mountains due to the influence of Atlantic deep pressure systems. In contrast, the eastern slopes of the Altai Mountains and Central Asia became arid during the Middle Holocene due to a weakening of the Pacific monsoon. Thus, Holocene vegetation and climate histories in the steppe regions west of the Altai Mountains are different from those in the regions east of the Altai Mountains (Chen et al., 2008; Rudaya et al., 2009, 2012).

\subsubsection{Holocene vegetation and climate histo- ries of the Mongol-Chinese steppe region}

The Early and Middle Holocene in northern Mongolia is characterised by increasing temperature and humidity as shown by many proxy data (e. g., lake levels, pollen assemblages, eolian sediment records) interrupted by some cold/dry reversals. Steppe vegetation was replaced by forest steppe and boreal woodland expanded (Gunin et al., 1999; Tarasov et al., 2000a; An et al., 2008; Rudaya et al., 2009; and literature cited therein). A decrease in precipitation and changes of vegetation towards steppe occurred at the end of the middle Holocene (Atlantic/Subboreal). Onset and termination of the dry interval differed from place to place (Yang et al., 2004; An et al., 2008). Humidity increased again during the late Holocene in concert with dropping temperatures in Mongolia.

Only few studies deal with southern Mongolia. During the early and middle Holocene, dark taiga forests apparently existed in the desert mountains of the Gobi Altai. Between 4000 to $3500 \mathrm{yr}$ BP the taiga forests disappeared due to aridization in southern Mongolia and were replaced by steppe vegetation (Jäger, 2005; Miehe et al., 2007). This is in line with more recent findings. Multi-proxy studies of lake sediments in the Gobi Desert (Bayan Tohomin Nur, Orog Nur) revealed a warm and humid period from the beginning of the Holocene at around 11 cal ka BP until about $3.5 \mathrm{cal}$ ka BP interrupted by some short-term cold/dry reversals. The late Pleistocene Artemisia steppe was altered to a Chenopodiaceae desert steppe in the Holocene (Felauer et al., 2012; Yu, 2016). Since about 3.5 cal ka BP aridity increased, Chenopodiaceae desert steppes expanded and the lake basins began to dry out. This southern Mongolian palaeoclimate scenario is more or less 
consistent with the palaeoclimatic data from northern Mongolia and surrounding regions of China.

In the last decades, many studies have been conducted in China to reconstruct past vegetation at a broad regional scale using multiple fossil pollen records and applying the biomization procedure $(\mathrm{Li}$ et al., 2014; Li, 2016, and literature cited therein). A huge area of northern China is dryland, comprising about one third of the Chinese landmass, and includes both arid and semi-arid regions. Vegetation types in these drylands are diverse and include desert, desert steppe, steppe and scrub-woodland. The boundary between arid and semi-arid regions runs along the Helan Mountains, approximately along $106^{\circ} \mathrm{E}$ longitude. Regions east of the Helan Mountains are influenced by the East Asian and Pacific summer monsoons and are semi-arid whereas the regions west of the Helan Mountains are arid, climatically mainly controlled by the dry and cold winter monsoon. In China's deserts, extensive lakes occurred during the late Pleistocene, and during the LGM steppe and desert vegetation extended to the modern coast of eastern China (Yang et al., 2011). In the first half of the Holocene, strengthened East Asian summer monsoons led to an increase in moisture in the entire dryland belt of northern China, and the mid-Holocene was warmer than today (Yang et al., 2011; Li et al., 2014). The deserts in northern China were greatly reduced and retreated northwestward. Biome reconstructions for the mid-Holocene revealed steppe as dominating vegetation type in the semi-arid regions east of the Helan Mountains and sites with forest and forest-steppe in the southern part of the east sandy land. West of the Helan Mountains, most of the regions were dominated by desert vegetation as today, but steppe vegetation is also recorded outside the deserts (Li et al., 2014).

A strengthening of the East Asian monsoon at 12 kyr BP associated with an increase in precipitation between 11 and $8 \mathrm{ka} \mathrm{BP}$ and a stepwise weakening of the monsoon circulation and climate aridization towards the modern level is mostly thought to be responsible for the Holocene climate change in Central Asia (Chen et al., 2008; Rudaya et al., 2009; Yang et al., 2011, and literature cited therein).

9.5.3 Synopsis of the Holocene climate and vegetation history of the Mongol-Chinese steppe region

A synopsis of climate and landscape changes and landscape changes and vegetation histories of the Mongol-Chinese steppe region during the Holocene is presented in Table 10, based mainly on fol- lowing literature: Gunin et al. (1999), Tarasov et al. (2000a), Miehe et al. (2007), An et al. (2008), Chen et al. (2008), Rudaya et al. (2009), Yang et al. (2011), Felauer et al. (2012), Li et al. (2014), Li (2016), and Yu (2016).

9.5.4 Holocene vegetation and climate histories of the Euro-Siberian steppe region

9.5.4.1 West Siberian Plain and Kazakhstan

At the beginning of the Holocene, steppe landscapes predominated in the present-day foreststeppe region of the West Siberian Plain (Arkhipov et al., 1999). With increasing warming (Boreal) forests extended during humid phases and steppe associations during dry phases. During the Atlantic period, forests expanded further, and forest-steppe emerged (Zhilich et al., 2017). Over the Holocene Optimum period, when mean annual temperatures were about $1{ }^{\circ} \mathrm{C}$ higher than present, forests contained also broad-leaved taxa like Tilia, Quercus, and Ulmus. Especially Tilia spread widely in the area of the modern West Siberian forest-steppe (Arkhipov et al., 1999). In the second half of the Holocene (Subboreal and Subatlantic) temperatures decreased and fluctuated around modern ones. Tree vegetation became impoverished and Betula-Pinus silvestris open forests spread (Arkhipov et al., 1999). From the early Atlantic to the early Subatlantic, forest-steppe and northern Kazakh steppe biomes moved several times beyond the present-day border up to $200 \mathrm{~km}$ to the North coincident with climate aridization (Zakh et al., 2010). The onset of the late Holocene is characterised by the dominance of steppe with birch and pine forests. This is consistent with the general pattern of mid-late Holocene vegetation and climate dynamics of the Kazakh Upland and western Altai (Rudaya et al., 2012).

Repeated climatic changes occurred in the steppe zone of Kazakhstan. A general warming trend from the beginning of the Holocene to the end of the Atlantic period is obvious. After that, temperatures fluctuated about $2-3{ }^{\circ} \mathrm{C}$ near the present values (Akhmetiev et al., 1999). Poaceae and Artemisia dry steppes dominated in the Kazakh steppe region at the beginning of the Holocene (Tarasov et al., 1997). In the early Atlantic period, birch forests expanded. From the late Atlantic on, Pinus silvestris penetrated from the southern Ural and west Siberia to northern and central Kazakhstan and spread throughout the steppe zone of Kazakhstan (Andreev, Tarasov, 2013). From that time on, vegetation cover received its present-day aspect (Tarasov et al., 1997; Akhmetiev et al., 1999; Andreev, Tarasov, 2013). 
Table 10

Holocene climate and vegetation histories in the Mongol-Chinese steppe region

\begin{tabular}{|c|c|c|c|}
\hline $\begin{array}{c}\text { Series/ } \\
\text { Subseries } \\
\text { Blytt-Sernander } \\
\text { classification } \\
\end{array}$ & Northern Mongolia & Southern Mongolia & Northern China \\
\hline $\begin{array}{c}\text { Late Holocene } \\
\text { (4.2 ka - to present) }\end{array}$ & $\begin{array}{l}\text { Modern natural vegetation: } \\
\text { Alpine vegetation, forest- } \\
\text { steppe, mountain steppe, } \\
\text { taiga, steppe and desert- } \\
\text { steppe }\end{array}$ & $\begin{array}{l}\text { Modern natural } \\
\text { vegetation: desert- } \\
\text { steppe, desert }\end{array}$ & $\begin{array}{l}\text { Modern natural vegetation: } \\
\text { desert-steppe and desert in } \\
\text { the NW; steppe and temperate } \\
\text { forests in NE }\end{array}$ \\
\hline $\begin{array}{l}\text { Second half of } \\
\text { Subboreal - } \\
\text { Subatlantic }\end{array}$ & $\begin{array}{l}\text { Dropping temperatures } \\
\text { and renewed increase of } \\
\text { humidity towards modern } \\
\text { levels }\end{array}$ & $\begin{array}{l}\text { Aridity increased, } \\
\text { Chenopodiaceen steppe } \\
\text { expanded }\end{array}$ & $\begin{array}{l}\text { Climate and vegetation } \\
\text { approaching modern levels }\end{array}$ \\
\hline $\begin{array}{l}\text { Middle Holocene } \\
\quad(8.2-4.2 \mathrm{ka})\end{array}$ & $\begin{array}{l}\text { Dry interval, vegetation } \\
\text { changed towards steppe }\end{array}$ & $\begin{array}{l}\text { Artemisia } \text { steppes } \\
\text { during wet phases, } \\
\text { Chenopodiaceen steppe } \\
\text { during dry phases }\end{array}$ & $\begin{array}{l}\text { Deserts retreated to NW (arid } \\
\text { climate), steppe dominating in } \\
\text { NE (semi-arid climate) }\end{array}$ \\
\hline $\begin{array}{l}\text { Middle and Late } \\
\text { Atlantic - First half } \\
\text { of Subboreal }\end{array}$ & \multirow[t]{2}{*}{$\begin{array}{l}\text { Steppe replaced by forest- } \\
\text { steppe, boreal woodland } \\
\text { expanded }\end{array}$} & \multirow[t]{2}{*}{$\begin{array}{l}\text { Taiga forests in the Gobi } \\
\text { Altai }\end{array}$} & \multirow{2}{*}{$\begin{array}{l}\text { Increase in moisture and } \\
\text { temperature in dryland belt, } \\
\text { Helan Mts. range (along } \\
106^{\circ} \mathrm{E} \text { longitude) became } \\
\text { meteorological divide }\end{array}$} \\
\hline $\begin{array}{l}\text { Early Holocene } \\
(11.7-8.2 \mathrm{ka})\end{array}$ & & & \\
\hline $\begin{array}{c}\text { Preboreal - Boreal - } \\
\text { Early Atlantic }\end{array}$ & $\begin{array}{l}\text { Increasing temperature and } \\
\text { humidity interrupted by } \\
\text { some cold/dry reversals }\end{array}$ & $\begin{array}{l}\text { Warm and humid period } \\
\text { interrupted by short } \\
\text { term cold/dry reversals }\end{array}$ & $\begin{array}{l}\text { At the end of the LGM dry land } \\
\text { belt from } \mathrm{W} \text { to E, desert and } \\
\text { steppe vegetation widespread }\end{array}$ \\
\hline
\end{tabular}

For references see text.

\subsubsection{Eastern Europe}

The modern zonal steppe in Europe stretches from the Ukrainian Black Sea coast over southern Russia further east to western Siberia. It was already Kleopov in the 1930ies who argued that the modern steppes of the Ukraine derived from 'near glacial' steppes in the beginning of the Holocene (Korotchenko, Peregrym, 2012). This view is currently widely accepted, not only for the Ukraine. Just recently, Pokorný et al. (2015) emphasized "that there is no doubt that the modern zonal steppes of Ukraine, Russia, Kazakhstan, Mongolia and northern China represent direct continuation of the Pleistocene glacial steppe". Biome reconstructions of the LGM biomes from pollen and macrofossil data compared with modern biomes support this view (Tarasov et al., 2000b; Binney et al., 2017).

The modern zonal forest-steppe in Europe adjoining the zonal steppe belt to the North, is confined to the Pannonian Basin, the lower course of the Danube, and a belt stretching from southeast of the Carpathians to the southern Urals. Contrasting views about the history of the European forest-steppe have been put forward, especially for central-eastern Europe: continuous persistence of steppe species since the Pleistocene versus their post-glacial immigration due to anthropogenic impact during the Holocene. Starting at the assumption that during the last Pleistocene glacial interval landscapes in the midlatitudes were characterised by a more or less open vegetation, convincing evidence accumulated to believe that in central and eastern Europe trees had a much wider distribution than previously assumed. The assumption of a nearly tree-less last-glacial landscape in eastern Europe and north of the Pyrenees, Alps and Carpathians was mainly based on pollen data. Emerging evidence from various fossil proxies, including plant macrofossils, macrofossil charcoal and dated pollen spectra, from palaeoclimate and biome modelling, and from genetic studies now begin to question this traditional view. It would appear that the central and eastern European landscape was partly covered by Taiga/montane woodland, which in some regions also contained isolat- 
ed pockets of temperate trees (Willis, Van Andel, 2004). Trees grew as far north as Hungary including species of Pinus, Picea, Betula, Juniperus, Salix, and Larix. Thermophilic trees as Carpinus betulus, Quercus, Corylus, Ulmus, and Tilia survived in favourable sites (Willis et al., 2000). Last pleniglacial pollen sequences from the Carpathian Basin and adjacent east Carpathians have been interpreted as reflecting a partially wooded boreal forest-steppe landscape (Magyari et al., 2014). Evidence for uninterrupted occurrence of forest-steppe since the late Pleistocene is also provided for the great Hungarian plain by Magyari et al. (2010), for northern Bohemia, Czech Republic, by Pokorný et al. (2015), and by Feurdean et al. (2015) for Transylvania. It is hypothesised that eurythermic steppe species survived the LGM in situ whereas thermophilic southern continental, Pontic and sub-Mediterranean steppe species immigrated in post-glacial time (Magyari et al., 2010). Thus, it would appear that many species of the central-eastern European forest-steppe persisted continuously since the late Pleistocene whereas others, mostly thermophilic ones are post-glacial immigrants.

9.5.5 Synopsis of the Holocene climate and vegetation history of the Euro-Siberian steppe region

A synopsis of climate and landscape changes and vegetation histories of the Euro-Siberian steppe region during the Holocene is presented in Table 11, based mainly on following literature.

References for eastern Europe: Lang (1994), Velichko (1999), Velichko et al. (1999), Tarasov et al. (2000b), Magyari et al. (2010, 2014), Feurdean et al. (2015) Pokorný et al. (2015), and Binney et al. (2017). References for West Siberian Plain and Kazakhstan: Tarasov et al. (1997), Velichko (1999), Arkhipov et al. (1999), Rudaya et al. (2012), Andreev and Tarasov (2013), and Zhilich et al. (2017).

\subsection{Azonal steppe islands in Central Europe}

The western-most outposts of Euro-Siberian steppe grassland are found in Central Europe: in the dry valleys of the Central Alps, in the upper Rhine valley in southwest Germany and adjacent Alsace, in central and southern Germany, and also in northern Bohemia, and in Lower Austria. These 'Steppenheide' (Gradmann, 1933) and 'Waldsteppeninseln'(Wendelberger, 1956) in middle and southeastern Europe are small mosaics of open dry grassland, shrubs and sparse woodland. They show many "forest-steppe" plants typical for the forest steppes of eastern Europe, however in different combinations and under different environmental and edaphic conditions than the true zonal forest steppe, and clearly represent azonal vegetation types within the zonal nemoral deciduous forest belt of Central Europe.

Origin of the extra-zonal small steppe islands in Central Europe is much debated. Gradmann (1933) thought that the roots of the Central European 'Steppenheide' reach back to the 'Dilluvium' (Pleistocene), and Wendelberger (1956) also argued that the Pannonian 'Waldsteppeninseln' house relics of the Pleistocene cold steppes (e.g., Eurotia ceratoides $=$ Krascheninnikovia ceratoides). Hejcman et al. (2013) basically share this view when writing that originally "they represent relicts of Pleistocene steppes".

Present vegetation in Central Europe is the result of anthropogenic transformation of the early Holocene woodlands into a cultivated landscape (Ellenberg, Leuschner, 2010). The opening of the forests by human activities started about 7000 years BP. One of the outcomes are different grassland communities, commercial grasslands (in terms of phytosociology, the class of the Molinio-Arrhenathera grasslands), and the fescue steppes and brome grasslands (Festuco-Brometea). The Festuco-Brometea is a poor grassland vegetation characterized by more or less basiphytic plant species in dry, warm areas on loess and sandy soils, often on carbonate rocks or steep slopes and similar exceptional habitats. They are composed either of mainly submediterranean-mediterranean geoelements (order Brometalia erecti) or of mainly pontic-sarmartic geoelements (order Festucetalia valesiacae, continental-subcontinental steppe grassland) (Pott, 1992). The origin of the Festucetalia valesiacae grasslands is interpreted as relics of the glacial steppes but their species composition and present locations are undoubtedly strongly influenced by human impact (Pott, 1995, 1996). Whether the concerned plants of the Festucetalia valesiacae are relics of the glacial cold steppe as Pott argues for, or rather are relics of a former continuous belt of continental steppe during the postglacial warm period as advocated by Ellenberg and Leuschner (2010), stands for question.

\section{Glacial and interglacial refuge areas}

\subsection{General Aspects}

The literature on 'refugia' is vast and has a long history. In the last two decades, debate on the refugia terminology has come up and led to an increase 
Table 11

Holocene climate and vegetation history in the Euro-Siberian steppe region

\begin{tabular}{|c|c|c|}
\hline $\begin{array}{c}\text { Series/ } \\
\text { Subseries } \\
\text { Blytt }- \text { Sernander classification }\end{array}$ & Eastern Europe & $\begin{array}{c}\text { West Siberian Plain and } \\
\text { Kazakhstan }\end{array}$ \\
\hline $\begin{array}{c}\text { Late Holocene } \\
(4.2 \mathrm{ka}-\text { to present })\end{array}$ & $\begin{array}{l}\text { Modern vegetation: forest-steppe } \\
\text { with Quercus forests in between } \\
\text { Tilia-Quercus forests, wet steppe, dry } \\
\text { steppe, desert steppe, deserts }\end{array}$ & $\begin{array}{l}\text { Modern vegetation: forest-steppe } \\
\text { with Betula-Pinus forests, wet } \\
\text { steppe, dry steppe, desert steppe, } \\
\text { deserts }\end{array}$ \\
\hline \multirow[t]{2}{*}{$\begin{array}{l}\text { Second half of Subboreal - } \\
\text { Subatlantic }\end{array}$} & $\begin{array}{l}\text { Increase of thermophilic trees during } \\
\text { warmings, decrease during coolings, } \\
\text { vegetation approaching } \\
\text { modern one }\end{array}$ & $\begin{array}{l}\text { Dominance of forest-steppe in } \\
\text { west Siberia, Kazakh upland and } \\
\text { western Altai, dry and semi-desert } \\
\text { steppe in northern Kazakhstan } \\
\text { lowlands }\end{array}$ \\
\hline & $\begin{array}{l}\text { Cooling trend to modern values, with } \\
\text { warmings and coolings }\end{array}$ & $\begin{array}{l}\text { Cooling trend to modern values, } \\
\text { with warmings and coolings }\end{array}$ \\
\hline \multirow{2}{*}{$\begin{array}{c}\text { Middle Holocene } \\
(8.2-4.2 \mathrm{ka}) \\
\\
\text { Middle and Late Atlantic - First } \\
\text { half of Subboreal }\end{array}$} & $\begin{array}{l}\text { At the beginning Pinus-Betula forest } \\
\text { vegetation, increase of thermophilic } \\
\text { trees (Tilia, Ulmus, Quercus) up to } \\
\text { Holocene Optimum }\end{array}$ & $\begin{array}{l}\text { At Holocene Optimum, forests } \\
\text { with thermophilic trees extended, } \\
\text { thereafter temperature decrease, } \\
\text { Betula-Pinus open forests spread }\end{array}$ \\
\hline & \multirow{2}{*}{$\begin{array}{l}\text { Forest-steppe from Pannonian Basin } \\
\text { to southern Urals and further east, } \\
\text { perhaps locally since late Pleistocene }\end{array}$} & $\begin{array}{l}\text { During Atlantic, Betula forests } \\
\text { expanded, forest-steppe emerged }\end{array}$ \\
\hline $\begin{array}{l}\text { Early Holocene } \\
(11.7-8.2 \mathrm{ka})\end{array}$ & & $\begin{array}{l}\text { in west Siberia, Pinus immigrated } \\
\text { into steppes of Kazakhstan }\end{array}$ \\
\hline \multirow{3}{*}{$\begin{array}{c}\text { Preboreal - Boreal - Early } \\
\text { Atlantic }\end{array}$} & Steppe from Ukrainian Black & Steppe in West Siberian Plain and \\
\hline & $\begin{array}{l}\text { Sea coast to southern Russia and } \\
\text { further east, continuously since late } \\
\text { Pleistocene }\end{array}$ & $\begin{array}{l}\text { Kazakhstan, continuously since late } \\
\text { Pleistocene }\end{array}$ \\
\hline & \multicolumn{2}{|c|}{ Warming trend to Holocene Optimum, several warming and cooling } \\
\hline
\end{tabular}

For references see text.

of refuge-related terms, a debate which often appears rather academic. Initially, the term 'refugia' was coined by biogeographers to describe localities where temperate species existed during glacial conditions and is thus synonymous with the common term 'glacial refugia' (Willis, Whittacker, 2000). The cyclic changes of the Pleistocene between cold (glacials) and warm (interglacials) periods resulted in expanding cold-adapted species during glacials and retracting during interglacials, and vice versa (warm-adapted, i.e. temperate species retracting during glacials and expanding during interglacials). Accordingly, 'cold stage refugia' (syn. glacial refugia) for warm-adapted taxa, and 'warm stage refugia' (syn. interglacial refugia) for cold-adapted taxa have been distinguished (e.g., Bennett, Provan, 2008; Stewart et al., 2010). Whereas glacial refugia attracted attention since long and continue to be widely discussed, interglacial refugia have long been neglected.

Many more different types of refugia have been proposed, as for instance 'palaeorefugia and neorefugia' (Nekola, 1999), 'macro- and microrefugia' (Rull, 2009), and 'nunatak, peripheral and lowland refugia' for mountain species (Holderegger, ThielEgenter, 2009). We refer to Tzedakis et al. (2013) who critically commented on these terms. To avoid terminological debate and to be in line with the terminology used in older literature, we will only use the terms 'glacial' and 'interglacial' refugia in its broadest sense referring "to an area, of any size, in which a taxon persisted, at any population density, during a cold [or warm] stage" (Bennett et al., 1991).

Glacial refugia - In Europe, classic southern glacial refugia for many plants (namely trees) and animals are supposed to be the Iberian, Italian and 
Balkan peninsulas, which has been substantiated by palaeontological, palaeoclimatological and genetic data (Frenzel, 1968b; Bennett et al., 1991; Willis, 1996; Taberlet et al., 1998; Hewitt, 1996, 1999, 2000; Petit et al., 2002). In addition to these southern refugia, it has become obvious that temperate species in Europe survived cold stages also north of the Pyrenees - Alps - Balkan mountain ranges in sheltered habitats with favourable microclimates. These refuge areas of warm-adapted species north of the classical southern glacial refugia have been termed 'cryptic refugia' (Stewart, Lister, 2001; Magri et al., 2006; Magri, 2008; Petit et al., 2008; Provan, Bennett, 2008; Tzedakis et al., 2013). Evidence for cryptic northern refugia comes from plant macrofossils, pollen records and genetic data. The original formulation of this hypothesis referred to temperate species but has taken on a wider meaning including boreal and hemiboreal species as well (see Stewart et al., 2010).

Interglacial refugia - In the Northern Hemisphere, cold-adapted species persist through interglacials in high-latitude regions known as "polar refugia'. Classical polar refugia in Eurasia are located in the northernmost parts of continental Eurasia and in several islands as, for instance, Greenland, Svalbard and Wrangel Island (Stewart et al., 2010). Interglacial refugia at lower latitudes are termed 'cryptic southern refugia' in parallel to the cryptic northern refugia although their present ranges are well known (in contrast to the original sense of cryptic refugia; Stewart et al., 2010). Refugial areas for those cryptic southern refugia are often mountains as the Alps and Pyrenees.

It should be kept in mind that a refugium is an area where distinct genetic lineages have persisted through a series of Tertiary or Quaternary climate fluctuations, and their locations are determined by complex historical and environmental factors. The modern structure of genetic diversity was shaped over multiple glacial-interglacial cycles rather than solely by the influence of the last glaciation period (e.g., Lavrenko et al., 1952; Bennett, Provan, 2008; Médail, Diadema, 2009).

10.2 Refuge areas of the Eurasian mid-latitudes

For a deeper understanding of the history of the mid-latitude eastern European and Asian fauna and flora (steppe biomes) we review present knowledge of refuge areas in these geographical regions. Early in the last century, the principal refugia in eastern Europe and Central Asia have been outlined by Lavrenko (1930) and Lavrenko et al. (1952). The most important centres from West to East were supposed to be the Carpathians, the uplands of the Ukraine and central (European) Russia, the southern Urals, and the Altai-Sayan mountain ranges. Meanwhile, this has been substantiated by many palaeobotanical data, biome reconstructions, modelling of palaeoenvironments, and by genetic studies, yet with main focus on forest tree. There are still considerable gaps in knowledge about grassland, especially steppe refugia.

\subsubsection{Forest tree refugia}

There is no doubt that many European trees survived the LGM in mountainous regions of the Iberian, Italian and Balkan peninsulas (the so-called southern refugia). The Carpathian Mts. as a northern cryptic glacial refugium for temperate trees has been corroborated by many studies (Lang, 1994; Birks, Willis, 2008; Magyari et al., 2014; see also chapter 9.5.4.2). Northern forest refugia have been also reconstructed in the uplands of European central Russia and Ukraine, in the Crimea and in the Caucasus (Markova et al., 2002, 2009). Climatically, they were all suitable for boreal tree species (Svenning et al., 2008). Nemoral tree species were largely restricted to the Black Sea region (Tarasov et al., 2000b; Markova et al., 2002, 2009; Svenning et al., 2008). The southern Urals as another cryptic cold-stage refugium for boreal and hemiboreal forest vegetation has also been confirmed (Ermakov, 1998; Birks, Willis, 2008; Chytrý et al., 2010).

A hemiboreal forest vegetation is also reported for the more humid and relatively warm foothills of the northern Altai Mts. (north of Lake Teletskoye) and for the mountain regions in the Kemerovo Region, Russia (Ermakov, 1998). Endemic to this region is Tilia sibirica, which is sometimes treated as a subspecies of $T$. cordata. In these linden-forests, several herbs typical for European temperate deciduous forests occur, separated by a gap of ca. $2000 \mathrm{~km}$ from their eastern limit of their continuous distribution range in the southern Urals (Ermakov, 1998). In the Russian literature, Tilia sibirica has since long been considered as a relict of Tertiary deciduous forests (Ermakov, 1998, and literature cited therein). A recent molecular study of Tilia sibirica confirmed the close relationship of $T$. sibirica to T. cordata and suggested middle Pleistocene divergence, ca. 450 kya (Logan et al., 2018). It is argued that the hemiboreal Tilia sibirica-forests can be considered as an analogue of a glacial refugium of temperate trees in Late Pleistocene (Novák et al., 2004; Hais et al., 2015; Logan et al., 2018). 


\subsubsection{Steppe refugia}

The term 'steppe' becomes problematic in the context of steppe refugia. Present-day steppe vegetation consists of cold-adapted and warm-adapted (thermophilic) species. Theoretically, one may argue that the cold-adapted species are presently in a warm-stage refugium (interglacial refugium) whereas the warm-adapted species are in expansion and question arises as to their cold-stage refugium (glacial refugium). This is further complicated by the fact that cold-adapted species often show high temperature tolerances and in reality should better be characterized as eurythermal instead of coldadapted. It has already been discussed that coldadapted or eurythermal species may have survived in in situ refugia whereas temperate-adapted species supposedly are immigrants from ex situ refugia. This is well investigated for the Carpathians and the Pannonian basin (see chapter 9.5.4.2).

As mentioned above, the principal refugia have been already outlined early in the last century. Some of these regions obviously are not only glacial but also interglacial refugia. Two examples will be given, one from eastern Europe, the other from the Altai-Sayan mountain region.

Eastern Europe - A conspicuous eastern European association of steppe plants confined mainly to calcareous outcrops (Schivereckia, Brassicaceae, and its associates) and its discontinuous distribution area (Urals, uplands of European Russia and the Ukraine) have since long attracted botanists. Schivereckia and its associates have been interpreted as relics of a formerly continuous distribution belt of periglacial steppe vegetation (Litvinov, 1902; Kozo-Poljanski, 1928, 1929; Gajewski, 1934) and thus would represent an interglacial refugium of LGM steppe vegetation.

Altai-Sayan Mts. - The southeastern Russian Altai harbours many Pleistocene relic species (e.g., Horsák et al., 2015 for plants and snails; PavelkováŘičánková et al., 2015 for mammals). Increasing evidence based on these findings and on fossil record argues for a modern analogue of the full-glaciated tundra-steppe ecosystem in the intermontane basins (e.g., Kurai and Chuya basins) and high mountain plateaus (e.g., Plateau Ukok) in the Altai-Sayan mountain country. It is likely that in some regions the present steppe biome is not only an analogue but also, at least partly, an in situ relic of the LGM tundra-steppe (reviewed in Chytrý et al., 2018). This assumption seems to be corroborated by modelling the spatial distribution of habitats during the LGM. The models projected the LGM predominance of desert steppe across most of the non-glaciated area of the Russian Altai, and it is argued that these desert steppes also supported the cold-adapted openlandscape biotas (Hais et al., 2015). However, Pleistocene relict species are presently concentrated in areas, which presumably were glaciated during the LGM or were flooded by ice-dammed lakes (e.g., Rudoy, 2002; Lehmkuhl et al., 2011; Blomdin et al., 2016). It is suggested that the LGM biota survived in nearby unglaciated or unflooded areas and returned to the deglaciated or dried areas during the late Glacial or Holocene.

Knowledge about cold-stage (glacial) refugia for thermophilic steppe plants is limited. As shown in Figure 2, during the LGM, steppe and desert steppe vegetation spread over interior regions of the Middle East and of Central Asia (Grichuk, 1992; Tarasov et al., 2000b; Andreev, Tarasov, 2007) and is also recorded from the region between the Black and Caspian Sea (Grichuk, 1992; see also Magyari et al., 2010). These biomes grow there also today. It is largely unknown which of the Euro-Siberian continental-subcontinental steppe species (mainly pontic-sarmartic geoelements from the order Festucetalia valesiacae) are cold-adapted, which are thermophilic, and which are eurythermal. In essence, the range of climatic tolerances of steppe plants is widely unknown. Apart from that, it stands for question whether the range of climatic tolerances of a living species allows conclusions about its temperature tolerances tens of thousands years ago. It is not without problems, therefore, to locate glacial refugia for thermophilic steppe species, except probably for submediterranean-mediterranean geoelements from the order Brometalia erecti.

In the Mongol-Chinese steppe region, vegetation during the LGM consisted to a large extend of steppe and desert biomes, periglacial tundra and steppe were nearly absent except for mountain regions (Fig. 2). Thus, LGM biota were similar to the preceding interglacial (Fig. 1) and to present-day conditions. Nevertheless, despite the absence of major Quaternary glaciations, significant climatic oscillations impacted the evolution of the biota. Climatic cycles consisted of dry glacial and humid interglacial periods, and plant species may have experienced glacial-time (arid periods) retreats and interglacial (humid periods) recolonizations. This is evidenced by several phylogeographic studies, summarized by Meng et al. (2015).

It is obvious that the florogenesis of present-day steppe vegetation is much more complicated than would be anticipated by mere shifting of vegetation belts. Geographical position of cold- and warmstage refugia, in situ survival and immigration fa- 
cilities from ex situ refugia, and competition have definitely influenced steppe florogenesis.

\section{Summary and outlook}

\subsection{The Eurasian steppe, Status Quo}

The term 'steppe' is of ambiguous meaning. In vegetation science and plant geography, 'steppe' is characterized as the naturally treeless climax formation of the semiarid regions within the cool-temperate (nemoral) vegetation zones, i.e. steppe and prairie in the Northern Hemisphere and pampas in the Southern Hemisphere. However, a 'treeless steppe' may also depend on various kinds of physical disturbances like grazing and fire. There are many attempts to fit the steppes into a global vegetation classification system, e.g., systems based on the zonal climax vegetation; or the WWF ecoregions and EUNIS (European Nature Information System) classifications.

Classification and nomenclature of steppe formations is rather vague and far from being standardized. Three main classification approaches can be recognized, the physiognomic approach, the dominant species approach, and the floristic approach. The dominant species approach is most successfully applied in Russian literature and is somehow in between the other two approaches. All classification principles have their advantages and disadvantages, and none alone is sufficient to cope with the steppe reality.

The Eurasian steppe belt can be divided into two subregions, the Euro-Siberian and Mongol-Chinese steppe. These two subregions differ in floristic, climatic and edaphic respects. The Altai Mountain Country and adjacent Tuva is the contact zone between the Euro-Siberian and Mongol-Chinese steppes, and comprise species of diverse floristic regions of different biogeographic origin.

Since thousands of years, the steppe biome is highly influenced, disturbed and transformed by human activities as agriculture and pastoralism. Today, natural or semi-natural steppe vegetation remains only in nature reserves, in gullies and ravines, on the slope of river valleys, on the edges of fields, and along roadsides. Steppes have become one of the most endangered terrestrial biomes but belong to the least protected areas worldwide. Main destructive threats are conversion of steppe into cropland, overgrazing, expanding mines, oil- and gasfields, urban encroachment, and afforestion. Magnitudes of these threats vary between regions. On top of all these threats come the effects of climate change. The impact of climate change is profound as evidenced by increased fire risks, for instance in Russia, and vanishing permafrost in Mongolia.

\subsection{Origin and evolutionary history of the Eurasian Steppe}

During the Palaeogene (Palaeocene to Oligocene) and at the beginning of the Neogene (Miocene) major reorganizations of climate, mountain ranges and oceans in northern Eurasia had major impacts on the origin and evolutionary history of the steppe. At the end of the Oligocene grass-dominated habitats appeared and became dominant biomes during the Neogene. The first steppes in Eurasia are recorded from Central Asia in the Palaeogene/early Miocene and later in Europe. Steppe habitats obviously are of multiple origins, originating at different places and at different times. A continuous Eurasian steppe belt established at the end of the Miocene/ early Pliocene as evidenced by the Hipparion (Pikermi) faunal complex. The Miocene landscape was the 'precursor' of the present day zonal landscape structure.

At the end of the Pliocene, vegetation cover in Eurasia consisted of forests in the North, forest steppe in southeastern Europe and the West Siberian Plain, and true steppes in Middle and Central Asia. Significant cooling at the end of the Pliocene marks the transition to the Pleistocene macrocycles of cold and warm periods. Waves of deep cooling and warming coupled with increased severity and duration of cold stages since the Middle Pleistocene had profound effects on the biota and the physical landscape and transformed the zonal landscape structure. Development of permafrost, formation of large continental ice sheets and loess deposition were intensified. During the cold stages (glacials), a cold steppe vegetation spread over northern Eurasia, and forests stretched from the Atlantic Ocean to the Ochotskoye Sea during the warm stages (interglacials). The cyclic changes of the Pleistocene between cold (glacials) and warm (interglacials) periods resulted in expanding cold-adapted species during glacials and retracting during interglacials, and vice versa. Accordingly, 'cold stage refugia' (syn. glacial refugia) for warm-adapted taxa, and 'warm stage refugia' (syn. interglacial refugia) for cold-adapted taxa have been distinguished.

Severity of continental climate reached a maximum in the Late Pleistocene when periglacial tundra and steppe dominated the higher northern and middle latitudes. Landscape zones shifted southwards by $10^{\circ}$ latitude. Repeated transgressions of 
the Caspian Sea and ice-dammed lakes caused longitudinal range splits of the cold steppe hyperzone. At the beginning of the Holocene, temperatures increased considerably and reached a maximum during the Mid-Holocene. With a shift to warmer and moister Holocene climates, the Pleistocene tundrasteppe hyperzone dispersed and was replaced by modern vegetation zones. The Altai Mountains became an important climate boundary. Wetter climate conditions prevailed west and north of the Altai Mountains whereas the eastern slopes of the Altai Mountains and Central Asia became arid during the Holocene. There have been major shifts in the distribution of animals and plants during the Holocene. Many Pleistocene environments, in which plant and animals coexisted in the late Pleistocene, were destroyed or fragmented, and possible relic areas have been proposed. This is an issue still under discussion.

\subsection{Challenges and outlook}

It would appear that the essential features of the origin and historical biogeography of the Eurasian steppe have been outlined in general. However, detailed knowledge and profound understanding are often limited or missing. Progress in Earth sciences and in palaeontological and geobotanical research, including the emerging ancient DNA studies, will definitely contribute to enhance our knowledge. We are also convinced of molecular-systematic approaches as a valuable tool for understanding the evolution of steppe. Contemporary genomes of steppe plants, up to a certain degree, document the evolutionary and biogeographical history of species, as has been shown by several studies. Testing the congruence of species phylogenies and landscape evolution has been greatly enhanced by molecular markers. Such studies analysed species histories for many parts of the world but are rare for steppe plants. We strongly propose to apply phylogeographic and biogeographic methods on steppe species to understand the geographic origin and the climate/landscape history of the Eurasian steppe belt.

Challenges of particular importance are the dynamics of steppe habitats in space and time, the evolution of the steppe flora (florogenesis), steppe refuge areas and the Holocene history of the European steppes.

Dynamics of steppe habitats - Palaeoclimatic oscillations, landscape history and tectonic processes led to repeated latitudinal shifts and longitudinal range splits of the steppe belt, which often caused range contractions and expansions of steppe habitats. Steppe habitats are of multiple origins. They developed at different places and at different times. We lack detailed knowledge about these fundamental processes and are far away from an all-embracing synthesis of the evolutionary history of the Eurasian steppe.

Florogenesis - The flora of the Eurasian steppe is different between its individual regions, both at a macrogeographical and at a microgeographical scale. The present-day flora of each region, irrespective of its extent, may have its own history. Origin of their floral elements and possible immigration routes at the species and genus level may differ not only between the regions but also within it. Geographic position of cold- and warm-stage refugia, in situ survival and immigration facilities from ex situ refugia as well as competition have definitely influenced steppe florogenesis.

Steppe refuge centres - Knowledge about steppe refuge areas is rather limited compared to tree refugia. This is especially true for possible 'cryptic' interglacial refugia and for glacial refugia of thermophilic species. Present-day steppe vegetation consists of cold-adapted and warm-adapted (thermophilic) species. Theoretically, cold-adapted species are presently in interglacial (warm-stage) refugia, whereas the thermophilic species are in expansion and question arises as to their glacial (cold-stage) refugia. This view, however, is complicated by the fact that cold-adapted steppe species often show high temperature tolerances and should better be characterized as eurythermal instead of cold-adapted species. Unfortunately, the range of climatic tolerances of Euro-Siberian continental-subcontinental steppe plants is widely unknown. In the MongolChinese steppe, we find another situation. Despite the absence of major Quaternary glaciations, plants may nonetheless have experienced glacial-time (arid periods) retreats and interglacial (humid periods) recolonizations.

Holocene history of the European steppe - A long-standing issue concerns two opposing hypotheses: continuous persistence of steppe species since the Pleistocene versus post-glacial immigration during the Holocene Climatic Optimum caused by climate change and anthropogenic activities. Occurrence of chernozems in central Europe and molecular studies are often used as aid to decision-making to distinguish between the two hypotheses.

The interpretation of chernozems as steppe soils goes back to the $19^{\text {th }}$ century Russian pedologist S.V. Dokuchaev. He argued that chernozems are climax soils above loess under the influence of steppe climates. Chernozems under forest-steppe are traditionally seen as a secondary phenomenon explained 
by forest penetration into initial chernozem steppe (Wilhelmy, 1950). Following these classical views, the black earth soils in central Europe (in Germany, Czech Republic, Austria and Hungary) are regarded as a relic of early Holocene soil formation (Preboreal and Boreal) and seem to testify steppe or foreststeppe biomes at the beginning of the early Holocene. A critical review on pedogenesis of chernozems by Eckmeier et al. (2007), however, revealed that the central European chernozems are of different ages (and not of uniform early Holocene age), that chernozems formed not only under steppe but also under forest vegetation, and that not all soils classified as chernozems in central Europe are steppe soils. Thus, origin and age of chernozems in central Europe do not necessarily reflect past climate and vegetation.

In the light of the few relevant molecular studies so far available, the matter has become even more complicated. It seems reasonable to suspect that an unambiguous decision in favour of one or the other of the two hypotheses is not possible. It would appear that eurythermic steppe species survived in situ, i.e. are relics of the cold Pleistocene periglacial tundra steppe, whereas the thermophilic species immigrated in post-glacial time. This has to be substantiated by identification of source areas and migration routes.
Outlook - The challenges outlined above impose several basic questions:

Do palaeoclimate oscillations and landscape evolution influence phylogenies and genetic subdivisions across species ranges? Do molecular signals mirror biogeographic dynamics and colonization of steppe habitats from different source populations? Can we identify source areas and migration routes?

Molecular phylogeographic studies including dated phylogenies and ancestral area reconstructions and correlation with climate/landscape history at the species and population level are necessary to answer these questions.

\section{Acknowledgements}

This work has been supported by the German Research Foundation (DFG; FR 1431/8-1 to NF; NE 314/15-1 to BN and HH; BL 462/18-1 to FB), by the Austrian Science Fund (FWF; Projekt 1 3002B25 to KGB) and by Russian Science Foundation (RSCF, Project 19-14-00071). Financial support for fieldwork and excursions by the DFG, DAAD, Ministry of Science and Culture of Lower Saxony, and the University of Osnabrueck is greatly acknowledged. We thank M. V. Markov, Tver and Moscow, and Z. Jamsran and B. Oyuntsetseg, Ulaanbaatar, for organizing excursions.

\section{References}

Abels H. A., Dupont-Nivet G., Xiao G., Bosboom R., Krijgsman W. 2011. Step-wise change of Asian interior climate preceding the Eocene-Oligocene Transition EOT. Palaeogeography, Palaeoclimatology, Palaeoecology 299: 399-412. DOI:10.1016/j.palaeo.2010.11.028.

Achilli A., Olivieri A., Soares P., Lancioni H., Hooshiar Kashani B., Perego U. A., Nergadze S. G., Carossa V., Santagostino M., Capomaccio S., Felicetti M., Al-Achkar W., Penedo M. C., Verini-Supplizi A., Houshmand M., Woodward S. R., Semino O., Silvestrelli M., Giulotto E., Pereira L., Bandelt H. J., Torroni A. 2012. Mitochondrial genomes from modern horses reveal the major haplogroups that underwent domestication. Proceedings of the National Academy of Sciences USA 109: 2449-2454. DOI: 10.1073/pnas.1111637109.

Akhmetiev M. A. 2010. Paleocene and Eocene floristic and climatic change in Russia and northern Kazakhstan. Bulletin of Geosciences 85: 17-34.

Akhmetiev M. A., Beniamovski V. N. 2009. Paleogene floral assemblages around epicontinental seas and straits in Northern Central Asia: proxies for climatic and paleogeographic evolution. Geologica Acta 7: 297-309.

Akhmetiev M. A., Dodonov A. E., Sotnikova M. V., Spasskaya I. I., Kremenetzky K. V., Klimanov V. A. 1999. Kazakhstan and Central Asia - plains and foothills. In: Climate and Environment Changes during the last 65 Million Years; Cenozoic: from Paleocene to Holocene. Eds. A. A. Velichko, V. P. Nechaev. Chapter 8. GEOS, Moscow, 165-191 pp. [In Russian]. (Ахметьев М. А., Додонов А. Е., Сотникова М. В., Спасская И. И., Кременецкий K. В., Климанов В. $\boldsymbol{A}$. Казахстан и Центральная Азия (равнины и предгорья) // Изменение климата и ландшафтов за последние 65 миллионов лет (кайнозой: от палеоцена до голоцена. Под ред. А. А. Величко, В. П. Нечаева. М.: ГЕОС, 1999. С. 165-191).

Akhmetiev M. A., Zaporozhets N. I. 2014. Paleogene events in central Eurasia: their role in the flora and vegetation cover evolution, migration of phytochore boundaries, and climate changes. Stratigraphy and Geological Correlation 22: 312-335. DOI: 10.1134/S0869593814030022.

Akhmetiev M. A., Zaporozhets N. I., Benyamosvky V. N., Aleksandrova G. N., Iakovleva A. I., Oreshkina T. V. 2012. The Paleogene history of the Western Siberian Seaway - a connection of the Peri-Tethys to the Arctic Ocean. Austrian Journal of Earth Sciences 105: 50-67. 
Alexandrova V. D. 1973. Russian approaches to classification in vegetation. In: Ordination and classification of communities. Ed. R. H. Whittacker. W. Junk, The Hague, 493-527 pp.

Allan H. H. 1946. Tussock grassland or steppe? The New Zealand Geographer 2: 223-234.

An C.-B., Chen F.-H., Barton L. 2008. Holocene environmental changes in Mongolia: A review. Global and Planetary Change 63: 283-289.

An Z., Kutzbach J. E., Prell W. L., Porter S. C. 2001. Evolution of Asian monsoons and phased uplift of the Himalaya-Tibetan plateau since Late Miocene times. Nature 411: 62-65.

Andreev A. A., Tarasov P. E. 2007. Northern Asia postglacial pollen records. In: Encyclopedia of Quaternary Science. Ed. S. Elias. Elsevier, Amsterdam, 2720-2729 pp.

Andreev A. A., Tarasov P. E. 2013. Northern Asia. In: The Encyclopedia of Quaternary Science. Ed. S. A. Elias. Vol. 4. Elsevier, Amsterdam, 164-172 pp.

Anthony D. W. 2007. The Horse, the Wheel, and Language: How Bronze-Age riders from the Eurasian Steppes shaped the Modern World. Princeton Univ. Press, Princeton, NJ, 568 pp.

Arkhipov S. A., Ehlers J., Johnson R. G., Wright Jr. H. E. 1995. Glacial drainage towards the Mediterranean during the middle and late Pleistocene. Boreas 24: 196-206.

Arkhipov S. A., Volkova V. S. 1994. Geological History of Pleistocene Landscapes and Climate in West Siberia. Novosibirsk, 105 pp. [In Russian]. (Архипов С. А., Волкова В. С. Геологическая история, ландшафты и климаты плейстоцеиа Западной Сибири. Новосибирск, 1994. 105 с.).

Arkhipov S. A., Volkova V. S., Zolnikov I. D., Zyklina V. S., Krukover A. A., Kulkova I. A. 1999. West Sibiria. In: Climate and Environment Changes during the last 65 Million Years; Cenozoic: from Paleocene to Holocene. Eds. A. A. Velichko, V. P. Nechaev. Chapter 4. GEOS, Moscow, 84-109 pp. [In Russian]. (Архипов С. А., Волкова В. С., Зольников И. Д., Зыкина В. С., Круковер А. А., Кулькова И. А. 1999. Западная Сибирь // Изменение климата и ландшафтов за последние 65 миллионов лет (кайнозой: от палеоцена до голоцена. Под ред. А. А. Величко, В. П. Нечаева. М.: ГЕОС. С. 84-109).

Astakhov V. I. 2006. Evidence of Late Pleistocene ice-dammed lakes in west Siberia. Boreas 35: 607-621.

Astakhov V. I. 2013. Pleistocene glaciations of northern Russia - a modern view. Boreas 42: 1-24. DOI: 10.1111/j.1502-3885.2012.00269.x.

Atlas of the USSR. 1986. Vegetation map. Moscow, 109-110 pp. [In Russian]. (Атлас СССР. Карта растительности. М., 1986. С. 109-110).

Azzaya D., Khaulenbek A. 2008. Evironmental and climate change in Mongolia. URL: www.ees.hokudai.ac.jp/ coe21/dc2008/EM/azzaya.pdf.

Bakker E. S., Gill J. L., Johnson C. N., Vera F. W. M., Sandom C. J., Asner G. P., Svenning J.-C. 2016. Combining paleo-data and modern exclosure experiments to assess the impact of megafauna extinctions on woody vegetation. Proceedings of the National Academy of Sciences USA 113: 847-855. DOI: 10.1073/pnas.1502545112.

Barnosky A. D., Koch P. L., Feranec R. S., Wing S. L., Shabel A. B. 2004. Assessing the causes of Late Pleistocene extinctions on the continents. Science 306: 70-75.

Bartlein P. J., Harrison S. P., Brewer S., Connor S., Davis B. A. S., Gajewski K., Guiot J., Harrison-Prentice T. I., Henderson A., Peyron O., Prentice I. C., Scholze M., Seppä H., Shuman B., Sugita S., Thompson R. S., Viau A. E., Williams J., Wu H. 2011. Pollen-based continental climate reconstructions at 6 and 21 ka: a global synthesis. Climate Dynamics 37: 775-802. DOI: 10.1007/s00382-010-0904-1.

Bartlett L. J., Williams D. R., Prescott G. W., Balmford A., Green R. E., Eriksson A., Valdes P. J., Singarayer J. S., Manica A. 2016. Robustness despite uncertainty: regional climate data reveal the dominant role of humans in explaining global extinctions of Late Quaternary megafauna. Ecography 39: 152-161. DOI: 10.1111/ecog.01566.

Baryshnikov G. F., Markova A. K. 1992. Map of Main Mammal Assemblages during maximum cooling of the last glaciation about 24.000 to $12.000 \mathrm{yr}$ B. P. and explanatory notes to the map. In: Atlas of Paleoclimates and Paleoenvironments of the Northern Hemisphere, Late Pleistocene-Holocene. Eds. B. Frenzel, M. Pécsi, A. A. Velichko. Gustav-Fischer-Verlag, Budapest, Stuttgart, 60-61 and 127-129 pp.

Bazha S. N., Gunin P. D., Danzhalova E. V., Drobyshev Y. I., Prishcepa A. V. 2012. Pastoral degradation of steppe ecosystems in Central Mongolia. In: Eurasian Steppes. Ecological problems and livelihoods in a changing world. Eds. M. J. A. Werger, M. A. van Staalduinen. Springer, Dordrecht, Heidelberg, New York, London, 289-319 pp.

Beerling D. J., Royer D. L. 2011. Convergent Cenozoic CO2 history. Nature Geoscience 4: 418-420.

Bennett K. D, Provan J. 2008. What do we mean by 'refugia'? Quaternary Science Reviews 27: 2449-2455.

Bennett K. D., Tzedakis P. C., Willis K. J. 1991. Quaternary refugia of north Europe. Journal of Biogeography 18: 103-115.

Bigelow N. H., Brubaker L. B., Edwards M. E., Harrison S. P., Prentice I. C., Anderson P. M., Andreev A. A., Bartlein P. J., Christensen T. R., Cramer W., Jed O., Kaplan J. O., Lozhkin A. V., Matveyeva N. V., Murray D. F., McGuire A. D., Razzhivin V. Y., Ritchie J. C., Smith B., Walker D. A., Gajewski G., Wolf V., Holmqvist B. H., Igarashi Y., Kremenetskii K., Paus A., Pisaric M. F. J., Volkova V. S. 2003. Climate change and Arctic ecosystems: 1. 
Vegetation changes north of $55^{\circ} \mathrm{N}$ between last glacial maximum, mid-Holocene, and present. Journal of Geophysical Research 108(D19): 8170. DOI: 10.1029/2002JD002558.

Binney H. A., Willis K. J., Edwards M. E., Bhagwat S. A., Anderson P. M., Andreev A. A., Blaauw M., Damblon F., Haesaerts P., Kienast F., Kremenetski K. V., Krivnogorov S. K., Lozhkin A. V., MacDonald G. M., Novenko A. Y., Oksanen P., Sapelko T. V., Väliranta M., Vazhenina L. 2009. The distribution of late-Quaternary woody taxa in northern Eurasia: evidence from a new macrofossil database. Quaternary Science Reviews 28: 2445-2464.

Binney H., Edwards M., Macias-Fauria M., Lozhkin A., Anderson P., Kaplan J. O., Andreev A., Bezrukova E., Blyakharchuk T., Jankovska V., Khazina I. K., Krivonogov S., Kremenetski K., Nield J., Novenko E., Ryabogina N., Solovieva N., Willis K., Zernitskaya V. 2017. Vegetation of Eurasia from the last glacial maximum to present: key biogeographic patterns. Quaternary Science Reviews 157: 80-97. DOI: 10.1016/j.quascirev.2016.11.022.

Birks H. J., Willis K. J. 2008. Alpines, trees, and refugia in Europe. Plant Ecology \& Diversity 1: 147-160.

Blomdin R., Heyman J., Stroeven A. P., Hättestrand C., Harbor J., Gribenski N., Jansson K. N., Petrakov D. A., Ivanov M. N., Alexander O., Rudoy A. N., Walther M. 2016. Glacial morphology of the Altai and Western Sayan Mountains, Central Asia. Journal of Maps 12(1): 123-136. DOI: 10.1080/17445647.2014.992177.

Bohn U., Neuhäusl R., Hettwer C. 2003. Theoretisches Konzept der Vegetationskarte. In: Map of the Natural Vegetation of Europe. Part 1: Explanatory Text. Eds. U. Bohn, G. Gollub, C. Hettwer, Z. Neuhäuslová, H. Schlüter, H. Weber. Published by Federal Agency for Nature Conservation BfN., Bonn, Germany. Landwirtschaftsverlag, Münster, 58-65 pp.

Bond W. J. 2008. What limits trees in $\mathrm{C}_{4}$ grasslands? Annual Review of Ecology, Evolution, and Systematics 39: 641-659.

Bond W. J., Woodward F. I., Midgley G. F. 2005. The global distribution of ecosystems in a world without fire. New Phytologist 165: 525-538.

Bosboom R. E., Dupont-Nivet G., Houben A. J. P., Brinkhuis H., Villa G., Mandic O., Stoica M., Zachariasse W. J., Guo Z., Li C., Krijgsman W. 2011. Late Eocene sea retreat from the Tarim Basin west China and concomitant Asian paleoenvironmental change. Palaeogeography, Palaeoclimatology, Palaeoecology 299: 385-398.

Bosboom R., Dupont-Nivet G., Grothe A., Brinkhuis H., Villa G., Mandic O., Stoica M., Huang W., Yang W., Guo Z., Krijgsman W. 2014. Linking Tarim Basin sea retreat (west China) and Asian aridification in the late Eocene. Basin Research 26: 621-640. DOI: 10.1111/bre.12054.

Bouchenak-Khelladi Y., Verboom G. A., Hodkinson T. R., Salamin N., Francois O., Ni Chonghaile G., Savolainen $\boldsymbol{V}$. 2009. The origins and diversification of $\mathrm{C}_{4}$ grasses and savanna-adapted ungulates. Global Change Biology 15: 2397-2417.

Bouchenak-Khelladi Y., Verboom G. A., Savolainen V., Hodkinson T. R. 2010. Biogeography of the grasses Poaceae: a phylogenetic approach to reveal evolutionary history in geographical space and geological time. Botanical Journal of the Linnean Society 162: 543-557.

Bouchenak-Khelladi Y., Muasya A. M., Linder H. P. 2014a. A revised evolutionary history of the Poales: origins and diversification. Botanical Journal of the Linnean Society 175: 4-16. DOI: 10.1111/boj.12160.

Bouchenak-Khelladi Y., Slingsby J. A., Verboom G. A., Bond W. J. 2014b. Diversification of $\mathrm{C}_{4}$ grasses Poaceae does not coincide with their ecological dominance. American Journal of Botany 101: 300-307. DOI: 10.3732/ ajb. 1300439.

Bougeois L., Dupont-Nivet G., de Rafélis M., Tindall J. C., Proust J.-N., Reichart G.-J., de Nooijer L. J., Gou Z., Ormukov C. 2018. Asian monsoons and aridification response to Paleogene sea retreat and Neogene westerly shielding indicated by seasonality in Paratethys oysters. Earth and Planetary Science Letters 485: 99-110. DOI: 10.1016/j.epsl.2017.12.036.

Brooks T. M., Bakarr M. I., Boucher T., Da Fonseca G. A. B., Hilton-Taylor C., Hoekstra J. M., Moritz T., Olivieri S., Parrish J., Pressey R. L., Rodrigues A. S. L., Sechrest W., Stattersfield A., Strahm W., Stuart S. N. 2004. Coverage provided by the global protected-area system: is it enough? BioScience 54: 1081-1091.

Bredenkamp G. J., Spada F., Kazmierzak E. 2002. On the origin of northern and southern hemisphere grasslands. Plant Ecology 163: 209-229.

Bruch A. A., Zhilin S. G. 2007. Early Miocene climate of Central Eurasia - evidence from Aquitanian floras of Kazakhstan. Palaeogeography, Palaeoclimatology, Palaeoecology 248: 32-48.

Bruch A. A., Uhl D., Mosbrugger V. 2007. Miocene climate in Europe - patterns and evolution. A first synthesis of NECLIME. Palaeogeography, Palaeoclimatology, Palaeoecology 253: 1-7.

Bruch A. A., Utescher T., Mosbrugger V. 2011. Precipitation patterns in the Miocene of Central Europe and the development of continentality. Palaeogeography, Palaeoclimatology, Palaeoecology 304: 202-211. DOI: 10.1016/j. palaeo.2010.10.002.

Büdel J. 1949a. Die räumliche und zeitliche Gliederung des Eiszeitalters. Die Naturwissenschaften 36: $105-112$.

Büdel J. 1949b. Die räumliche und zeitliche Gliederung des Eiszeitalters, Fortsetzung und Schluss. Die Naturwissenschaften 36: 133-139. 
Büdel J. 1951. Die Klimazonen des Eiszeitalters. Eiszeitalter und Gegenwart 1: 16-26.

Campos P. F., Willerslev E., Sher A., Orlando L., Axelsson E., Tikhonov A., Aaris-Sorensen K., Greenwood A. D., Kahlke R.-D., Kosintsev P., Krakhmalnaya T., Kuznetsova T., Lemey P., MacPhee R., Norris C. A., Shepherd K., Suchard M. A., Zazula G.D., Shapiro B., Gilbert M. T. 2010. Ancient DNA analyses exclude humans as the driving force behind late Pleistocene musk ox Ovibos moschatus population dynamics. Proceedings of the National Academy of Sciences USA 107: 5675-5680.

Caves J. K., Sjostrom D., Mix H. T., Winnick M. J., Chamberlain C. P. 2014. Aridification of Central Asia and uplift of the Altai and Hangay Mountains, Mongolia: stable isotope evidence. American Journal of Science 314: 1171-1201. DOI: 10.2475/08.2014.01.

Caves J. K., Winnick M. J., Graham S. A., Sjostrom D. J., Mulch A., Chamberlain C. P. 2015. Role of the westerlies in Central Asia climate over the Cenozoic. Earth and Planetary Science Letters 428: 33-43. DOI: 10.1016/j. eps1.2015.07.023.

Caves J. K., Moragne D. Y., Ibarra D. E., Bayshashov B. U., Gao Y., Jones M. M., Zhamangara A., Arzhannikova A. V., Arzhannikov S. G., Chamberlain C. P. 2016. The Neogene de-greening of Central Asia. Geology 44: 887-990. DOI: 10.1130/G38267.1.

Caves J. K., Zhamangara A., Ritch A. J., Ibarra D. E., Sjostrom D. J., Mix H. T., Winnick M. J., Chamberlain C. P. 2017. Late Miocene uplift of the Tian Shan and Altai and reorganization of Central Asian climate. Geological Society America Today 27, DOI: 10.1130/GSATG305A.1.

Cerling T. E., Wang Y., Quade J. 1993. Expansion of $\mathrm{C}_{4}$ ecosystems as an indicator of global ecological change in the late Miocene. Nature 361: 344-345.

Charles D. 2010. Renewing the post-Soviet steppe. Science 328: 1225.

Chen F., Yu Z., Yang M., Ito E., Wang S., Madsen D. B., Huang X., Zhao Y., Sato T., Birks H. J. B., Boomer I., Chen J., An C., Wünnemann B. 2008. Holocene moisture evolution in arid Central Asia and its out-of-phase relationship with Asian monsoon history. Quaternary Science Reviews 27: 351-364.

Chibilyov A. 2002. Steppe and forest-steppe. In Shagedano M., ed., The physical geography of northern Eurasia. Pp. 248-266. Oxford Univ. Press, Oxford.

Chlachula J. 2001a. Pleistocene climate change, natural environments and Palaeolithic occupation of the AngaraBaikal area, east-central Siberia. Quaternary International 80-81: 69-92.

Chlachula J. 2001b. Pleistocene climate change, natural environments and palaeolithic occupation of the upper Yenisei area, south-central Siberia. Quaternary International 80-81: 101-130.

Chlachula J. 2003. The Siberian loess record and its significance for reconstruction of Pleistocene climate change in north-central Asia. Quaternary Science Reviews 22: 1879-1906.

Chlachula J. 2010. Pleistocene climate change, natural environments and Palaeolithic occupation of East Kazakhstan. Quaternary International 220: 64-87.

Christin P.-A., Besnard G., Samaritani E., Duvall M. R., Hodkinson T. R., Savolainen V., Salamin N. 2008. Oligocene $\mathrm{CO}_{2}$ decline promoted $\mathrm{C}_{4}$ photosynthesis in grasses. Current Biology 18: 37-43.

Christin P.-A., Spriggs E., Osborne C. P., Strömberg C. A. E., Salamin N., Edwards E. J. 2014. Molecular dating, evolutionary rates, and the age of the grasses. Systematic Biology 63: 153-165. DOI: 10.1093/sysbio/syt072.

Chytrý M., Danihelka J., Horsák M., Koči, M., Kubešová S., Lososová Z., Otýpková Z., Tichý L., Martynenko V. B., Baisheva E. Z. 2010. Modern analogues from the Southern Urals provide insights into biodiversity change in the early Holocene forests of Central Europe. Journal of Biogeography 37: 767-780.

Chytrý M., Horsák M., Danihelka J., Ermakov N., German D. A., Hájek M., Hájková P., Koči M., Kubešova S., Lustyk P., Nekola J. C., Pavelková Řičánková V., Preislerová Z., Resl P., Valachovič M. 2018. A modern analogue of the Pleistocene steppe-tundra ecosystem in southern Siberia. Boreas 48(1): 36-56. DOI: 10.1111/bor.12338.

Cohen K. M., Gibbard P. I. 2011. Global chronostratigraphy and correlation table for the last 2.7 million years, updated version 2011, and comments which go with it. http: //www.quaternary. stratigraphy.org.uk/charts.

Cooper A., Turney C., Hughen K. A., Brook B. W., McDonald H. G., Bradshaw C. J. A. 2015. Abrupt warming events drove late Pleistocene Holarctic megafaunal turnover. Science 349: 602-606. DOI: 10.1126/science.aac4315.

Cotton J. L., Wysocki W. P., Clark L. G., Kelchner S. A., Pires J. C., Edger P. P., Mayfield-Jones D., Duvall M. R. 2015. Resolving deep relationships of PACMAD grasses: a phylogenomic approach. BMC Plant Biology 15: 178. DOI: $10.1186 / \mathrm{s} 12870-015-0563-9$.

Coupland R. T., ed. 1992. Natural Grasslands. Introduction and Western Hemisphere. Elsevier, Amsterdam.

Coupland R. T., ed. 1993. Natural Grasslands. Eastern Hemisphere and Résumé. Elsevier, Amsterdam.

Cowan P. J. 2007. Geographic usage of the terms Middle Asia and Central Asia. Journal of Arid Environments 69: 359-363.

Craine J. M., McLauchlan K. K. 2004. The influence of biotic drivers on North American palaeorecords: alternatives to climate. The Holocene 14: 787-791.

Crepet W. L., Feldman G. D. 1991. The earliest remains of grasses in the fossil record. American Journal of Botany 78: 1010-1014. 
Cui X., Guo K., Chen Z. 2012. Degradation and management of steppes in China. In: Eurasian Steppes. Ecological problems and livelihoods in a changing world. Eds. M. J. A. Werger, M. A. van Staalduinen. Springer, Dordrecht, Heidelberg, New York, London, 475-490 pp.

De Cáceres M., Chytrý M., Agrillo E., Attorre F., Botta-Dukát Z., Capelo J., Czúcz B., Dengler J., Ewald J., Faber-Langendoen D., Feoli E., Franklin S. B., Gavilán R., Gillet F., Jansen F., Jiménez-Alfaro B., Krestov P., Landucci F., Lengyel A., Loidi J., Mucina L., P et R. K., Roberts D. W., Roleček J., Schaminée J. H. J., Schmidtlein S., Theurillat J.-P., Tichý L., Walker D. A., Wildi O., Willner W., Wiser S. K. 2015. A comparative framework for broad-scale plot-based vegetation classification. Applied Vegetation Science 18(4): 543-560. DOI: 10.1111/ avsc. 12179

De Sò̀ R. 1929. Die Vegetation und Entstehung der ungarischen Puszta. Journal of Ecology 17: 329-350.

Dengler J., Janisová M., Török P., Wellstein C. 2014. Biodiversity of Palaearctic grasslands: a synthesis. Agriculture, Ecosystems and Environment 182: 1-14. DOI: 10.1016/j.agee.2013.12.015.

Denk T., Zohner C. M., Grimm G. W., Renner S. S. 2018. Plant fossils reveal biomes occupied by the late Miocene Old-World Pikermian fauna. Nature Ecology \& Evolution 2: 1864-1870. DOI: 10.1038/s41559-018-0695-z.

Devyatkin E. $\boldsymbol{V} .1993$. Meridional distribution of Pleistocene ecosystems in Asia: basic problems. Stratigraphy and Geological Correlation 1: 77-83.

Dolukhanov P. M., Chepalyga A. L., Shkatova V. K., Lavrentiev N. V. 2009. Late Quaternary Caspian: seal-levels, environments and human settlement. The Open Geography Journal 2: 1-15.

Dong M., Qiao J., Ye X., Liu G., Chu Y. 2012. Plant functional types across dune fixation stages in the Chinese steppe zone and their applicability for restoration of the desertified land. In: Eurasian steppes. Ecological problems and livelihoods in a changing world. Eds. M. J. A. Werger, M. A. van Staalduinen. Springer, Dordrecht, Heidelberg, New York, London, 321-334 pp.

Durka W., Nossol C., Welk E., Ruprecht E., Wagner V., Wesche K., Hensen I. 2013. Extreme depauperation and differentiation of both populations and species in Eurasian feather grasses Stipa. Plant Systematics and Evolution 299: 259-269. DOI: 10.1007/s00606-012-0719-0.

Dupont-Nivet G., Krijgsman W., Langereis C.G., Abels H. A., Dai S., Fang X. 2007. Tibetan Plateau aridification linked to global cooling at the Eocene-Oligocene transition. Nature 445: 635-638.

Dupont-Nivet G., Hoorn C., Konert M. 2008. Tibetan uplift prior to the Eocene-Oligocene climate transition: evidence from pollen analysis of the Xining Basin. Geology 36: 987-990.

Eckmeier E., Gerlach R., Gehrt E., Schmidt M. W. I. 2007. Pedogenesis of chernozems in Central Europe - A review. Geoderma 139: 288-299.

Edwards E. J., Smith S. A. 2010. Phylogenetic analyses reveal the shady history of $\mathrm{C}_{4}$ grasses. Proceedings of the National Academy of Science USA 107: 2532-2537.

Edwards E. J., Osborne C. P., Strömberg C. A. E., Smith S. A., Bond W. J., Christin P. A., Cousins A. B., Duvall M. R., Fox D. L., Freckleton R. P., Ghannoum O., Hartwell J., Huang Y., Janis C. M., Keeley J. E., Kellogg E. A., Knapp A. K., Leakey A. D., Nelson D. M., Saarela J. M., Sage R. F., Sala O. E., Salamin N., Still C. J., Tipple B. 2010. The origins of $\mathrm{C}_{4}$ grasslands: integrating evolutionary and ecosystem science. Science 328: 587-591.

Ehlers J., Gibbard P. 2011. Quaternary Glaciation. In: Encyclopedia of Snow, Ice and Glaciers. Eds. V. P. Singh, P. Singh, U. K. Haritashya. Springer Science + Business Media BV.V., 873-882 pp.

Ehlers J., Astakhov V., Gibbard P. L., Mangerud J., Svendsen J. I. 2013a. Late Pleistocene in Eurasia. In: Encyclopedia of Quaternary Science, 2nd edition. Eds. S. A. Elias, C. M. Mock. Vol. 2. Elsevier, Amsterdam, 224-235 pp.

Ehlers J., Astakhov V., Gibbard P. L., Mangerud J., Svendsen J. I. 2013b. Middle Pleistocene in Eurasia. In: Encyclopedia of Quaternary Science, 2nd edition. Eds. S. A. Elias, C. M. Mock. Vol. 2. Elsevier, Amsterdam, 172-179 pp.

Ellenberg H., Leuschner C. 2010. Vegetation Mitteleuropas mit den Alpen. 6th edition. Eugen Ulmer, Stuttgart, 1095 pp.

Ellenberg H., Mueller-Dombois D. 1967a. Tentative physiognomic-ecological classification of plant formations of the earth. Berichte Geobotanisches Institut ETH Zürich, Stiftung Rübel 37: 21-55.

Ellenberg H., Mueller-Dombois D. 1967b. A key to Raunkiaer plant life forms with revised subdivisions. Berichte Geobotanisches Institut ETH Zürich, Stiftung Rübel 37: 56-73.

Erbajeva M., Alexeeva N. 2013. Late Cenozoic mammal faunas of the Baikalian region: composition, biochronology, dispersal, and correlation with central Asia. In: Fossil mammals of Asia: Neogene biostratigraphy and chronology. Eds. X. Wang, L. J. Flynn, M. Fortelius Columbia Univ. Press, 495-507 pp.

Ermakov N. 1998. The Altaian relict subnemoral forest belt and the vegetation of the pre-Pleistocene mountainous landscapes. Phytocoenologia 28: 31-44.

Eronen J. 2006. Eurasian Neogene large herbivorous mammals and climate. Acta Zoologica Fennica 216: 1-72.

Eronen J. T., Mirzaie Ataabadi M., Micheels A., Karme A., Bernor R. L., Fortelius M. 2009. History and climatic controls of the Late Miocene Pikermian chronofauna. Proceedings of the National Academy of Sciences USA 106: 11867-11871. 
Eronen J., Puolamäki K., Lintulaakso K., Damuth J., Janis C., Fortelius M. 2010. Precipitation and large herbivorous mammals II: application to fossil data. Evolutionary Ecology Research 12: 235-248.

FAO 2001. Global ecological zoning for the global forest resources assessment 2000. Forest Resources Assessment Programme, Working Paper 56. FAO, Rome.

FAO 2012. Global ecological zones for FAO forest reporting: 2010 update. Forest Resources Assessment Paper 179. FAO, Rome.

FAO 2015. World reference base for soil resources 2014, update 2015. World Soil Resources Reports No. 106. FAO, Rome.

FAO-Unesco 1971-1981. Soil map of the world, 1:5 Mill., vol. 1-10. Unesco, Paris.

Felauer T., Schlütz F., Murad W., Mischke S., Lehmkuhl F. 2012. Late Quaternary climate and landscape evolution in arid Central Asia: a multiproxy study of lake archive Bayan Tohomin Nuur, Gobi desert, southern Mongolia. Journal of Asian Earth Sciences 48: 125-135.

Feurdean A., Marinova E., Nielsen A. B., Liakka J., Veres D., Hutchinson S. M., Braun M., Timar-Gabor A., Astalos C., Mosburgger V., Hickler T. 2015. Origin of the forest steppe and exceptional grassland diversity in Transylvania central-eastern Europe. Journal of Biogeography 42: 951-963. DOI: 10.1111/jbi.12468.

Figueirido B., Janis C. M., Pérez-Claros J. A., De Renzi M., Palmquist P. 2012. Cenozoic climate change influences mammalian evolutionary dynamics. Proceedings of the National Academy of Sciences USA 109: 722-727. DOI: 10.1073/pnas.1110246108.

Fortelius M., Eronen J., Liu L., Pushkina D., Tesakov A., Vislobokova I., Zhang Z. 2006. Late Miocene and Pliocene large mammals and climatic change in Eurasia. Palaeogeography, Paleoclimatology, Palaeoecology 238: 219-227.

Fortelius M., Eronen J. T., Kaya F., Tang H., Raia P., Puolamäki K. 2014. Evolution of Neogene mammals in Eurasia: environmental forcing and biotic interactions. Annual Review of Earth and Planetary Sciences 42: 579-604. DOI: 10.1146/annurev-earth-050212-124030.

Fradkina A. F., Alekseev M. N., Andreev A. A., Klimanov V. A. 1999a. East Siberia based on data obtained mainly in Central Yakutia. In: Climate and Environment Changes during the last 65 Million Years; Cenozoic: from Paleocene to Holocene. Eds. A. A. Velichko, V. P. Nechaev. Chapter 5. GEOS, Moscow, 110-127 pp. [In Russian]. (Фрадкина A. Ф., Алексеев М. Н., Андреев А. А., Климанов В. А. Восточная Сибирь (на примере Центральной Якутии) // Изменение климата и ландшафтов за последние 65 миллионов лет (кайнозой: от палеоцена до голоцена. Под ред. А. А. Величко, В. П. Нечаева. М.: ГЕОС, 1999. С. 110-127).

Fradkina A. F., Grinenko O. V., Laukhin S. A., Nechaev V. P., Andreev A. A., Klimanov V. A. 1999b. Northeastern Asia. In: Climate and Environment Changes during the last 65 Million Years; Cenozoic: from Paleocene to Holocene. Eds. A. A. Velichko, V. P. Nechaev. Chapter 6. GEOS, Moscow, 128-145 pp. [In Russian]. (Фрадкина А. Ф., Гриненнко О. В., Лаухин С. А., Нечаев В. П., Андреев А. А., Климанов В. А. Северо-Восток // Изменение климата и ландшафтов за последние 65 миллионов лет (кайнозой: от палеоцена до голоцена. Под ред. А. А. Величко, В. П. Нечаева. М.: ГЕОС, 1999. С. 128-145).

Francois L., Bruch A., Utescher T., Spicer R.A., Spicer T. 2017. Reconstructing Cenozoic vegetation from proxy data and models - a NECLIME synthesis Editorial. Palaeogeography, Paleoclimatology, Palaeoecology 467: 1-4. DOI: i:10.1016/j.palaeo.2016.11.04.

Franzke A., Hurka H., Janssen D., Neuffer B., Friesen N., Markov, M. V., Mummenhoff K. 2004. Molecular signals for Late Tertiary/Early Quaternary range splits of an Eurasian steppe plant: Clausia aprica (Brassicaceae). Molecular Ecology 13: 2789-2795.

Frenzel B. 1968a. Grundzüge der pleistozänen Vegetationsgeschichte Nord-Eurasiens. Steiner, Wiesbaden.

Frenzel B. 1968b. The Pleistocene vegetation of northern Eurasia. Science 161: 637-649.

Frenzel B. 1979. Europe without forests. Geographical Magazine 1979: 756-761.

Frenzel B. 1992. Map of Vegetation during maximum cooling of the last glaciation about 20.000 to $18.000 \mathrm{yr}$ B.P. and explanatory notes to the map. In: Atlas of Paleoclimates and Paleoenvironments of the Northern Hemisphere, Late Pleistocene - Holocene. Eds. B. Frenzel, M. Pécsi, A. A. Velichko. Gustav-Fischer-Verlag, Budapest, Stuttgart, 55 and $122 \mathrm{pp}$.

Frenzel B., Pécsi M., Velichko A. A., eds. 1992. Atlas of Paleoclimates and Paleoenvironments of the Northern Hemisphere, Late Pleistocene - Holocene. Gustav-Fischer-Verlag, Budapest, Stuttgart, 153 pp.

Friesen N., German D. A., Hurka H., Herden T., Oyuntsetseg B., Neuffer B. 2016. Dated phylogenies and historical biogeography of Dontostemon and Clausia (Brassicaceae) mirror the palaeogeographical history of the Eurasian steppe. Journal of Biogeography 43: 738-749. DOI: 10.1111/jbi.12658.

Gadghiev I. M., Korolyuk A. Y., Tytlyanova A. A., Andievsky V. S., Bayatogtokh B., Grishina L. G., Kosykh N. P., Kyrgys C. O., Mironycheva-Zokareva N. P., Romanova I. P., Sambuu A. D., Smelyansky I. E. 2002. Steppes of Central Asia. Novosibirsk, 299 pp. [In Russian]. (Гаджсиев И. М., Королюк А. Ю., Титлянова А. А., Андиевский В. С., Баяртогтох Б., Гришина Л. Г., Косых Н. П., Кыргыс Ч. О., Миронычева-Токарева Н. П., Романова И. П., Самбуа А. Д., Смелянский И. Е. Степи Центральной Азии. Новосибирск, 2002. 299 с.). 
Gajewski M. W. 1934. Avenetum desertorum, a monographical study. Bulletin International de l'Académie Polonaise des Sciences et des Lettres. Classe des Sciences Mathématiques et Naturelles, Série B: Sciences Naturelles 1: $1-27$.

Gibbard P., Head M. J. 2009. The definition of the Quaternary system/era and the Pleistocene series/epoch. Quaternaire 20: 125-133.

Gibson D. J. 2009. Grasses and Grassland Ecology. Oxford University Press, New York, 305 pp.

Gomes Rodrigues H., Marivaux L., Vianey-Liaud M. 2012. Expansion of open landscapes in Northern China during the Oligocene induced by dramatic climate changes: paleoecological evidence. Palaeogeogrgaphy, Palaeoclimatology, Palaeoecology 358-360: 62-71. DOI: 10.1016/j.palaeo.2012.07.025.

GPWG II 2012. New grass phylogeny resolves deep evolutionary relationships and discovers $\mathrm{C}_{4}$ origins. New Phytologist 193: 304-312.

Gradmann R. 1933. Die Steppenheidetheorie. Geographische Zeitschrift 39: 265-278.

Gribova S. A., Karamysheva Z. V., Neuhäusl R., Yurkovskaya T. K. 1988. Vegetation map of Europe and the problems of classification. In: Geobotanical Mapping 1988. Leningrad, 3-13 pp. [In Russian]. (Грибова С. А., Карамышева 3. В., Нейхейсл Р., Юрковская $\boldsymbol{T}$. К. Карта растительности Европы и проблемы классификации // Геоботаническое картографирование 1988. Л., 1988. С. 3-13).

Grichuk V.P. 1992. Map of Main Types of Vegetation Ecosystems during maximum cooling of the last glaciation about 20.000 to $18.000 \mathrm{yr}$ B.P. and explanatory notes to the map. In: Atlas of Paleoclimates and Paleoenvironments of the Northern Hemisphere, Late Pleistocene - Holocene. Eds. B. Frenzel, M. Pécsi, A. A. Velichko. Gustav-FischerVerlag, Budapest, Stuttgart, 57 and 123-124 pp.

Gunin P. D., Vostokova E. A., Dorofeyuk N. I., Tarasov P. E., Black C. C. 1999. Vegetation Dynamics of Mongolia. Chapter 2: Late Quaternary vegetation history of Mongolia. Kluwer Acad. Publ., Dordrecht, The Netherlands, 45-77 pp.

Guo Z. T., Sun B., Zhang Z. S., Peng S. Z., Xiao G. Q., Ge J. Y., Hao Q. Z., Qiao Y. S., Liang M. Y., Liu J. F., Yin Q. Z., Wei J. J. 2008. A major reorganization of Asian climate by the early Miocene. Climate of the Past 4: $153-174$.

Guo Z., Cui G. 2015. Establishment of nature reserves in administrative regions of mainland China. PLoS ONE 10(3): e0119650. DOI: 10.1371/journal.pone.0119650

Guo Z. T., Ruddiman W. F., Hao Q. Z., Wu H. B., Qiao Y. S., Zhu R. X., Peng S. Z., Wel, J. J., Yuan B. Y., Liu T. S. 2002. Onset of Asian desertification by 22 Myr ago inferred from loess deposits in China. Nature 416: $159-163$.

Guthrie R. D. 1982. Mammals of the mammoth steppe as palaeoenvironmental indicators. In: Palaeoecology of Beringia. Eds. D. M. Hopkins, Jr. J. V. Matthews, C. E. Schweger, S. B. Young. Acad. Press, New York, London, 307-326 pp.

Guthrie R. D. 2001. Origin and causes of the mammoth steppe: a story of cloud cover, woolly mammal tooth pits, buckles, and inside-out Beringia. Quaternary Science Reviews 20: 549-574.

Hais M., Komprdová K., Ermakov N., Chytry M. 2015. Modelling the Last Glacial Maximum environments for a refugium of Pleistocene biota in the Russian Altai Mountains, Siberia. Palaeogeography, Palaeoclimatology, Palaeoecology 438: 135-145. DOI: 10.1016/j.palaeo.2015.07.037.

Hanks B. 2010. Archeology of the Eurasian steppes and Mongolia. Annual Review of Anthropology 39: 469-486.

Hansen J., Sato M., Russel G., Kharecha P. 2013. Climate sensitivity, sea level and atmospheric carbon dioxide. Philosophical Transactions of the Royal Society A 371, 20120294. DOI: 10.1098/rsta.2012.0294.

Harzhauser M., Piller W. E. 2007. Benchmark data of a changing sea - palaeogeography, palaeobiogeography and events in the Central Paratethys during the Miocene. Palaeogeography, Palaeoclimatology, Palaeoecology 253: 8-31.

Harzhauser M., Daxner-Höck G., López-Guerrero P., Maridet O., Oliver A., Piller W. E., Richoz S., Erbajeva M. A., Neubauer T. A., Göhlich U. B. 2016. Stepwise onset of the Icehouse world and its impact on Oligo-Miocene Central Asian mammals. Scientific Reports 6: 36169. DOI: 10.1038/srep36169.

Head M. J., Gibbard P., Salvador A. 2008a. The Quaternary: its character and definition. Episodes 31(2): 234-238.

Head M. J., Pillans B., Farquhar S. 2008b. The Early-Middle Pleistocene transition: characterization and proposed guide for the defining boundary. Episodes 31(2): 255-259.

Hejcman M., Hejcmanová P., Pavlu V., Benes J. 2013. Origin and history of grasslands in Central Europe - a review. Grass and Forage Science 68: 345-363. DOI: 10.1111/gfs.12066.

Hewitt G. M. 1996. Some genetic consequences of ice ages, and their role in divergence and speciation. Biological Journal of the Linnean Society 58: 247-276.

Hewitt G. M. 1999. Molecular genetics in animal ecology. Biological Journal of the Linnean Society 68: 87-112.

Hewitt G. M. 2000. The genetic legacy of the Quaternary ice ages. Nature 405: 907-913.

Hibbert D. 1982. History of the steppe-tundra concept. In: Paleoecology of Beringia. Eds. D. M. Hopkins, Jr. J. V. Matthews, C. E. Schweger, S. B. Young. Acad. Press, New York, London, 153-156 pp.

Hilbig $\boldsymbol{W}$. 1995. The Vegetation of Mongolia. SPB Academic Publishing, Amsterdam, 258 pp.

Hilbig $\boldsymbol{W}$. 2000. Kommentierte Übersicht über die Pflanzengesellschaften und ihre höheren Syntaxa in der Mongolei. Feddes Repertorium 111: 75-120. 
Hilbig $\boldsymbol{W}$. 2006. Der Beitrag deutscher Botaniker an der Erforschung von Flora und Vegetation in der Mongolei. Feddes Repertorium 117: 321-366.

Hirsch H., Wagner V., Danihelka J., Ruprecht E., Sánchez-Gómez P., Seifert M., Hensen I. 2015. High genetic diversity declines towards the geographic range periphery of Adonis vernalis, a Eurasian dry grassland plant. Plant Biology 17: 1233-1241. DOI: 10.1111/plb.12362.

Hölzel N., Haub C., Ingelfinger M. P., Otte A., Pilipenko V. N. 2002. The return of the steppe - large-scale restoration of degraded land in southern Russia during the post-Soviet era. Journal of Nature Conservation 10: 75-85.

Holderegger R., Thiel-Egenter C. 2009. A discussion of different types of glacial refugia used in mountain biogeography and phylogeography. Journal of Biogeography 36: 476-480.

Hooker J. J., Collinson M. E., Sille N. P. 2004. Eocene-Oligocene mammalian faunal turnover in the Hampshire Basin, UK: calibration to the global time scale and the major cooling event. Journal Geological Society London 161: 161-172.

Horsák M., Chytrý M., Hájková P., Hájek M., Danihelka J., Horsáková V., Ermakov N., German D. A., Koči M., Lustyk P., Nekola J. C., Preislerová Z., Valachovič M. 2015. European glacial relict snails and plants: environmental context of their modern refugial occurrence in southern Siberia. Boreas 44: 638-657. DOI: 10.1111/bor.12133.

Hu Z., Zhang D. 2003. China's pasture resources. In: Transhumant grazing systems in temperate Asia. Eds. J. M. Suttie, S. G. Reynolds. Chapter V. Plant Production and Protection Series No. 31. FAO, Rome, 81-113 pp.

Huber M., Goldner A. 2012. Eocene monsoons. Journal of Asian Earth Sciences 44: 3-23.

Hurka H., Friesen N., German D. A., Franzke A., Neuffer B. 2012. 'Missing link' species Capsella orientalis and Capsella thracica elucidate evolution of model plant genus Capsella (Brassicaceae). Molecular Ecology 21: 1223-1238. DOI: 10.1111/j.1365-294X.2012.05460.x.

Ivanov D., Utescher T., Mosbrugger V., Syabryaj S., Djordjevic-Milutinovic D., Molchanoff S. 2011. Miocene vegetation and climate dynamics in Eastern and Central Paratethys southeastern Europe. Palaeogeography, Palaeoclimatology, Palaeoecology 304: 262-275. DOI: 10.1016/j.palaeo.2010.07.006.

Jacobs B. F., Kingstone J. D., Jacobs L. L. 1999. The origin of grassland-dominated ecosystems. Annals Missouri Botanical Garden 86: 590-643.

Jacques F. M. B., Shi G., Wang W. 2013. Neogene zonal vegetation of China and the evolution of the winter monsoon. Bulletin of Geoscience 88: 175-193.

Jäger E. J. 2005. The occurrence of forest plants in the desert mountains of Mongolia and their bearing on the history of the climate. In: Exploration into the Biological Resources of Mongolia. Bd. 9. Martin-Luther-Universitat Halle-Wittenberg, Halle (Saale), 237-245 pp.

Jia G., Peng P., Zhao Q., Jian Z. 2003. Changes in terrestrial ecosystems since 30 Ma in East Asia: stable isotope evidence from black carbon in the South China Sea. Geology 31: 1093-1096.

Jiang H., Ding Z. 2009. Spatial and temporal characteristics of Neogene palynoflora in China and its implication for the spread of steppe vegetation. Journal of Arid Environments 73: 765-772.

Jones S. S., Burke S. V., Duvall M. R. 2014. Phylogenomics, molecular evolution, and estimated ages of lineages from the deep phylogeny of Poaceae. Plant Systematics and Evolution 300: 1421-1436. DOI: 10.1007/s00606-0130971-y.

Joppa L. N., Pfaff A. 2009. High and far: biases in the location of protected areas. PLoS ONE 4: e8273.

Kahlke R.-D. 2014. The origin of Eurasian Mammoth faunas Mammuthus - Coelodonta complex. Quaternary Science Reviews 96: 32-49. DOI: 10.1016/j.quascirev.2013.01.012.

Kajtoch L., Ciéslak E., Varga Z., Paul, W., Mazur M. A., Sramkó G., Kubisz D. 2016. Phylogeographic patterns of steppe species in Eastern Europe: a review and the implications for conservation. Biodiversity and Conservation 25: 2309-2339. DOI: 10.1007/s10531-016-1065-2.

Kalis A. J., Merkt J., Wunderlich J. 2003. Environmental changes during the Holocene climatic optimum in central Europe - human impact and natural causes. Quaternary Science Reviews 22: 33-79.

Kamelin R. V. 1998. Materials on the History of the Flora of Asia: the Altai Montane Country. Altai University Press, Barnaul, 239 pp. (Камелин P. В. Материалы по истории флоры Азии (Алтайская горная страна). Барнаул: Изд-во Алт. ун-та, 1998. 239 с.).

Kamelin R. V. 2005. New flora of Altai (tasks and conception of the new floristic summary). In: Flora Altaya [Flora of Altai]. Vol. 1. Ed. R. V. Kamelin. Azbuka, Barnaul, 7-22 pp. [In Russian]. (Камелин Р. В. Новая флора Алтая (Задачи и концепция новой флористической сводки) // Флора Алтая. Т. 1. Ред. Р. В. Камелин. Барнаул: Азбука, 2005. С. 7-22).

Kamp J., Urazaliev R., Donald P. F., Hölzel N. 2011. Post-Soviet agricultural change predicts future declines after recent recovery in Eurasian steppe bird populations. Biological Conservation 144: 2607-2614. DOI: 10.1016/j. biocon.2011.07.010.

Karamysheva Z. V., Khramtsov V. N. 1995. The steppes of Mongolia. Braun-Blanquetia 17: 1-79. 
Kaya F., Bibi F., Žliobaite I., Eronene J. T., Hui T., Fortelius M. 2018. The rise and fall of the Old World savannah fauna and the origins of the African savannah biome. Nature Ecology \& Evolution 2: 241-246. DOI: 10.1038/ s41559-017-0414-1.

Keeley J. E., Rundel P. W. 2005. Fire and the Miocene expansion of $\mathrm{C}_{4}$ grasslands. Ecology Letters 8: 683-690.

Kellogg E. A. 2015. Flowering Plants. Monocots, Poaceae. In: The Families and Genera of Vacular Plants. Ed. K. Kubitzki. Vol. 13. Springer, Heidelberg, 416 pp.

Kienast F., Schirrmeister L., Siegert C., Tarasov P. 2005. Palaeobotanical evidence for warm summers in the East Siberian Arctic during the last cold stage. Quaternary Research 63: 283-300.

Kirilyuk O. K. 2014. Development of an effective protected areas network in the north-eastern Daurian ecoregion. In: Proceedings of the International Conference of China-Mongolia-Russia Daurian International Protected Area. Eds. B. Bayarbaatar, J. K. Smith, A. Edwards, O. Lkhamjav. Wildlife Conservation Society Mongolia, Ulaanbaatar, 18-20 pp.

Kirilyuk V. E., Obyazov V. A., Tkachuk T. E., Kirilyuk O. K. 2012. Influence of climate change on vegetation and wildlife in the Daurian Eco-region. In: Eurasian steppes. Ecological problems and livelihoods in a changing world. Eds. M. J. A. Werger, M. A. van Staalduinen. Springer, Dordrecht, Heidelberg, New York, London, $397-424$ pp.

Knapp H. D. 2005. Vegetationsregionen und Schutzgebiete in Europa. In: Anwendungen und Auswertung der Karte der natürlichen Vegetation Europas. Eds. U. Bohn, C. Hettwer, G. Gollub. Bundesamt für Naturschutz, BfN, Skripten 156, Bonn,165-194 pp.

Kong Y., Wang C.-H. 2017. Responses and changes in the permafrost and snow water equivalent in the Northern Hemisphere under a scenario of $1.5^{\circ} \mathrm{C}$ warming. Advances in Climate Research 8: 235-244. DOI: 10.1016/j. accre.2017.07.002.

Korotchenko I., Peregrym M. 2012. Ukrainian steppes in the past, at present and in the future. In: Eurasian steppes. Ecological problems and livelihoods in a changing world. Eds. M. J. A. Werger, M. A. van Staalduinen. Springer, Dordrecht, Heidelberg, New York, London, 173-196 pp.

Korotky A. M., Volkov T. A., Grebennikova T. A., Razzhigaeva N. G., Pushkar V. S., Ganzei L. A., Mokhova L. M. 1999. Far East. In: Climate and Environment Changes during the last 65 Million Years; Cenozoic: from Paleocene to Holocene. Eds. A. A. Velichko, V. P. Nechaev. Chapter 7. GEOS, Moscow, 146-164 pp. [In Russian].

Kovar-Eder J., Kvaček Z., Martinetto E., Roiron P. 2006. Late Miocene to Early Pliocene vegetation of southern Europe 7-4 Ma as reflected in the megafossil plant record. Palaeogeography, Palaeoclimatology, Palaeoecology 238: 321-339.

Kovar-Eder J., Jechorek H., Kvaček Z., Parashiv V. 2008. The integrated plant record: an essential tool for reconstructing Neogene zonal vegetation in Europe. Palaios 23: 97-111.

Kozo-Poljanski B. M. 1928. Glaziale Pflanzenrelikte auf dem Orel-Kurskischen Plateau im Süden der Mittelrussischen Hochebene I. Vegetationsbilder. G. Fischer, Jena. Reihe 19, Heft 1/2. Tafel 1-12.

Kozo-Poljanski B. M. 1929. Glaziale Pflanzenrelikte auf dem Orel-Kurskischen Plateau im Süden der Mittelrussischen Hochebene II. Vegetationsbilder. G. Fischer, Jena. Reihe 19, Heft 7/8. Tafel 37-48.

Kuneš P., Pokorný P., Š́da P. 2008. Detection of impact of early Holocene hunter-gatherers on vegetation in the Czech Republic, using multivariate analysis of pollen data. Vegetation History Archaeobotany 17: $269-287$.

Lang G. 1994. Quartäre Vegetationsgeschichte Europas. Fischer, Jena, 462 pp.

Lavrenko E. M. 1930. Forest relicts (Tertiary) centers between the Carpathians and Altai. Zhurnal Russkogo Botanicheskogo Obshchestva 15: 351-363 [In Russian]. (Лавренко Е. М. Лесные реликтовые центры между Карпатами и Алтаем. Журн. Русского Бот. Об-ва, 1930. Т. 15. С. 351-363).

Lavrenko E. M. 1969. Über die Lage des Euroasiatischen Steppengebiets in dem System der pflanzengeographischen Gliederung des außertropischen Eurasiens. Vegetatio 19: 11-20.

Lavrenko E. M. 1970a. Division of the Black Sea - Kazakhstan subregion of the Eurasian steppe region. Bot. Zhurn. (Moscow \& Leningrad) 55(5): 609-625 [In Russian]. (Лавренко Е. М. Провинциальное разделение Причерноморско-Казахстанской подобласти Степной области Евразии // Бот. журн., 1970. Т. 55, № 5. С. 609-625).

Lavrenko E. M. 1970b. Division of the Central Asian subregion of the steppe region of Eurasia. Bot. Zhurn. (Moscow \& Leningrad) 55(12): 1734-1741 [In Russian]. (Лавренко Е. М. Провинциальное разделение Центральноазиатской подобласти Степной области Евразии // Бот. журн., 1970. Т. 55, № 12. С. 1734-1741).

Lavrenko E. M., Govorukhin V. S., Puzanov P. I. 1952. The Holarctic region. In: Great Soviet Encyclopaedia, second edition. Vol. 11. Moscow, 587-593 pp. [In Russian]. (Лавренко Е. М., Говорухин В. С., Пузанов И. И. Голарктическая область // Большая советская энциклопедия. Изд-е 2-е. Т. 11. М.: Большая сов. энциклопедия, 1952. С. 587-593).

Lavrenko E. M., Karamysheva Z. V. 1993. Steppes of the former Soviet Union and Mongolia. In: Natural Grasslands. Eastern Hemisphere and Resume. Ed. R. T. Coupland. Elsevier, Amsterdam, 3-59 pp.

Lavrenko E. M., Karamysheva Z. V., Nikulina R. I. 1991. Steppes of Eurasia. Nauka, Leningrad, 146 pp. [In Russian]. (Лавренко Е. М., Карамышева З. В., Никулина Р. И. Степи Евразии. Л.: Наука, 1991. 146 с.). 
Lehmkuhl F., Klinge M., Stauch G. 2011. The extent and timing of Late Pleistocene glaciations in the Altai and neighbouring mountain systems. In: Developments in Quaternary Science. Eds. J. Ehlers, P. L. Gibbard, P. D. Hughes. Vol. 15. Elsevier, Amsterdam, 967-979 pp.

Levykin S. V., Chibilyov A. A., Kazachkov G. V. 2012. Land use modernization and agrarian and conservation prospects in the Russian steppe. In: Eurasian steppes. Ecological problems and livelihoods in a changing world. Eds. M. J. A. Werger, M. A. van Staalduinen. Springer, Dordrecht, Heidelberg, New York, London, 491-505 pp.

Li F. 2016. Pollen productivity estimates and pollen-based reconstructions of Holocene vegetation cover in northern and temperate China for climate modelling. PhD Thesis, Linnaeus University Kalmar. Linnaeus University Press, Växjö, Sweden.

Li Q., Wи Н., Gио Z., Yи Y., Ge J., Wи J., Zhao D., Sun A. 2014. Distribution and vegetation reconstruction of the deserts of northern China during the mid-Holocene. Geophysical Research Letters 41: 5184-5191. DOI: 10.1002/2014GL059952.

Li X., Zhang R., Zhang Z., Yan Q. 2018. What enhanced the aridity in Eocene Asian inland: global cooling or early Tibetan Plateau uplift? Palaeogeography, Palaeoclimatology, Palaeoecology 510: 6-14. DOI: 10.1016/j. palaeo.2017.10.029.

Licht A., van Cappelle M., Abels H. A., Ladant J.-B., Trabucho-Alexandre J., France-Lanord C., Donnadieu Y., Vandenberghe J., Rigaudier T., Lécuyer C., Terry Jr. D., Adriaens R., Boura A., Guo Z., Naing Soe A., Quade J., Dupont-Nivet G., Jaeger J.-J. 2014. Asian monsoons in a late Eocene greenhouse world. Nature 513: 501-506. DOI: $10.1038 /$ nature13704.

Linder H. P., Lehmann C. E. R., Archibald S., Osborne C. P., Richardson D. M. 2018. Global grass (Poaceae) success underpinned by traits facilitating colonization, persistence and habitat transformation. Biological Reviews 93: 1125-1144. DOI: 10.1111/brv.12388.

Linder H. P., Rudall P. J. 2005. Evolutionary history of Poales. Annual Review of Ecology and Systematics 36: 107-124.

Lippert P. C., van Hinsbergen D. J. J., Dupont-Nivet G. 2014. Early Cretaceous to present latitude of the central Tibetan Plateau: a paleomagnetic synthesis with implications for Cenozoic tectonics, paleogeography, and climate of Asia. In: Toward an improved understanding of uplift mechanisms and the elevation history of the Tibetan Plateau. Geological Soceity of America, Special Paper 507. Eds. J. Nie, B. K. Horton, G. D. Hoke. 1-21 pp. DOI: 10.1130/2014.2507(01).

Lister A. M., Stuart A. J. 2008. The impact of climate change on large mammal distribution and extinction: evidence from the last glacial/interglacial transition. Comptes Rendus Geoscience 340: 615-620.

Litvinov D. J. 1902. About the relic character of stony slopes in European Russia. Traveaux Musee Botanique Academie St. Petersburg 1: 76-109 [In Russian] (Литвинов Д. И. О реликтовом характере флоры каменистых склонов в Европейской России // Труды Ботанического музея Академии наук, 1902. Т. 1. С. 76-109).

Liu J., Li J. J., Song H. Y., Peng T. J., Hui Z. C., Ye X. Y. 2016. Palynological evidence for late Miocene stepwise aridification on the northeastern Tibetan Plateau. Climate of the Past 12: 1473-1484. DOI: 10.5194/cp-12-1473-2016.

Liu L., Eronen J. T., Fortelius M. 2009. Significant mid-latitude aridity in the middle Miocene of East Asia. Palaeogeography, Palaeoclimatology, Palaeoecology 279: 201-206.

Liu Y.-S., Utescher T., Zhou Z., Sun B. 2011. The evolution of Miocene climates in North China: preliminary results of quantitative reconstructions from plant fossil records. Palaeogeorgaphy, Palaeoclimatology, Palaeoecology 304: 308-317. DOI: 10.1016/j.palaeo.2010.07.004.

Logan S. A., Chytrý M., Wolff K. 2018. Genetic diversity and demographic history of the Siberian lime (Tilia sibirica). Perspectives in Plant Ecology, Evolution and Systematics 33: 9-17. DOI: 10.1016/j.ppees.2018.04.005.

Lи H. Y., Guo Z. T. 2014. Evolution of the monsoon and dry climate in East Asia during late Cenozoic: a review. Science China: Earth Sciences 57: 70-79. DOI: 10.1007/s11430-013-4790-3.

Magri D. 2008. Patterns of post-glacial spread and the extent of glacial refugia of European beech Fagus sylvatica. Journal of Biogeography 35: 450-463.

Magri D., Vendramin G. G., Comps B., Dupanloup I., Geburek T., Gömöry D., Latalova M., Litt T., Paule L., Roure J. M., Tantau J., van der Knaap W. O., Petit R. J., de Beaulieu J.-L. 2006. A new scenario for the Quaternary history of European beech populations: palaeobotanical evidence and genetic consequences. New Phytologist 171: 199-221.

Magyari E. K., Chapman J. C., Passmore D. G., Allen J. R. M., Huntley J. P., Huntley B. 2010. Holocene persistence of wooded steppe in the Great Hungarian Plain. Journal of Biogeography 37: 915-935. DOI: 10.1111/j.13652699.2009.02261.x.

Magyari E. K., Kuně̌ P., Jakab G., Sümegi P., Pelánková, B., Schäbitz F., Braun M., Chytrý M. 2014. Late pleniglacial vegetation in eastern-central Europe: are there modern analogues in Siberia? Quaternary Science Reviews 95: 60-79. DOI: 10.1016/j.quascirev.2014.04.020.

Mai D. H. 1995. Tertiäre Vegetationsgeschichte Europas. Fischer, Stuttgart, 691 pp. 
Malhi Y., Doughty C. E., Galetti M., Smith F. A., Svenning J.-C., Terborgh J. W. 2016. Megafauna and ecosystem function from the Pleistocene to the Anthropocene. Proceedings National Academy of Sciences USA 113: 838-846. DOI: 10.1073/pnas.1502540113.

Malyshev L. I. 2000. Floristic division on the quantitative basis: Baikalian Siberia, Tuva and Outer Mongolia. Flora 195: 330-338.

Malyshev L. I., Baikov K. S., Doronkin V. M. 1999. Spatial diversity of the Siberian flora. Flora 194: 357-368.

Mangerud J., Andersen S. T., Berglund B. E., Donner J. J. 1974. Quaternary stratigraphy of Norden, a proposal for terminology and classification. Boreas 3: 109-128.

Mangerud J., Astakhov V. I., Murray A., Svendsen J. I. 2001. The chronology of a large ice-dammed lake and the Barents-Kara Ice Sheet advance. Global and Planetary Change 31: 321-336.

Markova A. K., Simakova A. N., Puzachenko A. Yu. 2002. Ecosystems of Eastern Europe in the Late Glacial Maximum of the Valdai glaciation (24-18 ka B.P) based on floristic and theriological data. Doklady Earth Sciences 387: 925-928.

Markova A. K., Simakova A. N., Puzachenko A. Yu. 2009. Ecosystems of Eastern Europe at the time of maximum cooling of the Valdai glaciation (24-18 ka BP) inferred from data on plant communities and mammal assemblages. Quaternary International 201: 53-59.

Martin P. S. 1984. Prehistoric overkill: the global model. In: Quaternary Extinctions: A Prehistoric Revolution. Eds. P. S. Martin, R. G. Klein. Univ. Arizona Press, Tucson, Arizona, 354-403 pp.

McDonald G. M., Beiman D. W., Kuzmin Y. V., Orlaova L. A., Kremenetski K. V., Shapiro B., Wayne R. K., Van Valkenburg B. 2012. Pattern of extinction of the woolly mammoth in Beringia. Nature Communications 3: 893. DOI: 10.1038/ncomms 1881 .

Médail F., Diadema K. 2009. Glacial refugia influence plant diversity patterns in the Mediterranean Basin. Journal of Biogeography 36: 1333-1345.

Meindl C., Brune V., Listl D., Poschlod P., Reisch C. 2016. Survival and postglacial immigration of the steppe plant Scorzonera purpurea to Central Europe. Plant Systematics Evolution 302: 971-984. DOI: 10.1007/s00606-0161311-9.

Meng H.-H., Gao X.-Y., Huang J.-F., Zhang M.-L. 2015. Plant phylogeography in arid Northwest China: retrospectives and perspectives. Journal of Systematics and Evolution 53: 33-46. DOI: 10.1111/jse.12088.

Meng J., McKenna M. C. 1998. Faunal turnovers of Palaeogene mammals from the Mongolian Plateau. Nature 394: 364-367.

Meng Q.-T., Bruch A. A., Sun G., Liu Z.-J., Hu F., Sun P.-C. 2018. Quantitative reconstruction of Middle and Late Eocene plaeoclimate based on palynological records from the Huadian Basin, northeastern China: evidence for monsoonal influence on oil shale formation. Palaeogeography, Palaeoclimatology, Palaeoecology 510: 63-77. DOI: 10.1016/j.palaeo.2017.11.036.

Menzel L., Kopp B., Munkhjargal M. 2016. Does mountain permafrost in Mongolia control water availability? Geophysical research Abstracts. Vol. 18. EGU2016-9325, EGU General Assembly 2016.

Meusel H., Jäger E. 1992. Vergleichende Chorologie der zentraleuropäischen Flora. Vol. 3. Fischer, Jena, 688 pp.

Meusel H., Jäger E., Weinert E. 1965. Vergleichende Chorologie der zentraleuropäischen Flora. Vol. 1. Fischer, Jena, 583 pp.

Meusel H., Jäger E., Rauschert S., Weinert E. 1978. Vergleichende Chorologie der zentraleuropäischen Flora. Vol. 2. Fischer, Jena, $421 \mathrm{pp}$.

Miehe G., Schlütz F., Miehe S., Opgenoorth L., Cermak J., Samiya R., Jäger E. J., Wesche K. 2007. Mountain forest islands and Holocene environmental changes in Central Asia: a case study from the southern Gobi Altay, Mongolia. Palaeogeography, Palaeoclimatology, Palaeoecology 250: 150-166.

Miller Rosen A., Chang C., Grigoriev F. 2000. Paleoenvironments and economy of Iron Age Saka-Wusun agropastoralists in southern Kazakhstan. Antiquity 74: 611-623.

Molnar P., Boos W. R., Battisti D. S. 2010. Orographic controls on climate and paleoclimate of Asia: thermal and mechanical roles for the Tibetan Plateau. Annual Review of Earth and Planetary Sciences 38: 77-102.

Molnár Z., Biró M., Bartha S., Fekete G. 2012. Past trends, present state and future prospects of Hungarian foreststeppes. In: Eurasian steppes. Ecological problems and livelihoods in a changing world. Eds. M. J. A. Werger, M. A. van Staalduinen. Springer, Dordrecht, Heidelberg, New York, London, 209-252 pp.

Moysiyenko I. I., Zachwatowicz M., Sudnik-Wójcikowska B., Jablonska E. 2014. Kurgans help to protect endangered steppe species in the Pontic grass steppe zone, Ukraine. Wulfenia 21: 83-94.

Mucina L. 2013. Ecosystems of Europe. In: Encyclopedia of Biodiversity, 2nd editon. Ed. S. A. Levin. Vol. 3. Academic Press, Waltham, MA, 333-346 pp.

Mudelsee M., Bickert T., Lear C., Lohmann G. 2014. Cenozoic climate changes: a review based on time series analysis of marine benthic $\delta 180$ records. Reviews of Geophysics 52: 333-374. DOI: 10.1002/2013RG000440. 
Murphy E. M., Schulting R., Beer N., Christov Y., Kasparov A., Pshenitsyna M. 2013. Iron Age pastoral nomadism and agriculture in the eastern Eurasian steppe: implications from dental palaeopathology and stable carbon and nitrogen isotopes. Journal of Archaeological Science 40: 2547-2560. DOI: 10.1016/j.jas.2012.09.038.

Naafs B. D. A., Rohrssen M., Inglis G. N., Lähteenoja S. J., Feakins S. J., Collinson M. E., Kennedy E. M., Singh P. K., Singh M. P., Lunt D. J., Pancost R. D. 2018. High temperatures in the terrestrial mid-latitudes during the early Palaeogene. Nature Geoscience 11: 766-771. DOI: 10.1038/s41561-018-0199-0.

Nehring A. 1890. Über die Tundren und Steppen der Jetzt- und Vorzeit, mit besonderer Berücksichtigung ihrer Fauna. F. Dümmler, Berlin, 257 pp.

Nekola J. C. 1999. Paleorefugia and neorefugia: the influence of colonization history on community pattern and process. Ecology 80: 2459-2473.

Neronov V. M., Lishchekina A. A., Karimova T. Y., Arylova N. Y. 2012. Population dynamics of a key steppe species in a changing world: the critically endangered Saiga antelope. In: Eurasian steppes. Ecological problems and livelihoods in a changing world. Eds. M. J. A. Werger, M. A. van Staalduinen. Springer, Dordrecht, Heidelberg, New York, London, 335-356 pp.

Novák J., Trotsiuk V., Sýkora O., Svoboda M., Chytry M. 2014. Ecology of Tilia sibirica in a continental hemiboreal forest, southern Siberia: an analogue of a glacial refugium of broad-leaved temperate trees? The Holocene 24: 908-918. DOI: 10.1177/0959683614534744.

Olson D. M., Dinerstein E., Wikramanayake E. D., Burgess N. D., Powell G. V. N., Underwood E. C., D'amico J. A., Itoua I., Strand H. E., Morrison J. C., Loucks C. J., Allnutt T. F., Ricketts T. H., Kura Y., Lamoreux J. F., Wettengel W. W., Hedao P., Kassem K. R. 2001. Terrestrial ecoregions of the world: a new map of life on earth. BioScience 51: 933-938.

Owen L. A. 2013. Late Quaternary in highland Asia. In: Encyclopedia of Quaternary Science, 2nd edition. Eds. S. A. Elias, C. M. Mock. Vol. 2. Elsevier, Amsterdam, 236-244 pp.

Owen-Smith N. 1987. Pleistocene extinctions: the pivotal role of megaherbivores. Paleobiology 13: 351-362.

Pälike H., Norris R.D., Herrle J.O., Wilson P. A., Coxall H. K., Lear C., Shackleton N. J., Tripati A. K., Wade B. S. 2006. The heartbeat of the Oligocene climate system. Science 314: 1894-1898.

Parzinger H. 2006. Die frühen Völker Eurasiens: Vom Neolithikum bis zum Mittelalter. C. H. Beck, München, 1044 pp.

Parzinger H. 2009. Die Skythen. 3rd edition. C. H. Beck, München, 128 pp.

Pavelková Řičánková V., Horsák M., Hais M., Robovský J., Chytrý M. 2015. Environmental correlates of the Late Quaternary regional extinctions of large and small Palaearctic mammals. Ecography 41: 516-527. DOI: 10.1111/ ecog.02851.

Pavleychik V. M. 2015. Steppe fires and environmental management modernization problems. In: Problems of Geo-Ecology and Degree Studies. Vol. IV. Optimization of the land fund structure and environmental management in steppe regions of Russia. Ed. A. A. Chibilev. IS of UBRAS, Orenburg, 40-50 pp. [In Russian]. (Павлейчик В. М. Степные пожары и проблемы модернизации природопользования // Проблемы геоэкологии и степеведения. T. IV. Оптимизация структуры земельного фонда и модернизация природопользования в степных регионах России. Ред. А. А. Чибилев. Оренбург: ИС УрО РАН, 2015. С. 40-50).

Pavleychik V. M. 2016. On the issue of the intensification of steppe fires on the example of the Zavolzhsko-Uralsky region. Bulletin of the Voronezh State University, ser. Geography. Geoecology 3: 15-25 [In Russian]. (Павлейчик $\boldsymbol{B}$. M. К вопросу об активизации степных пожаров на примере Заволжско-Уральского региона // Вестник Воронежского государственного университетаю Сер. География. Геоэкология, 2016. № 3. С. 15-25).

Pavleychik V. M. 2017. Actual problems of investigation and monitoring steppe fires at the example of Zavolzhie and south Ural regions. Problems of Ecological Monitoring and Modelling of Ecosystems 28(2): 86-99 [In Russian]. (Павлейчик В. М. Актуальные проблемы изучения и мониторинга степных пожаров на примере ЗаволжскоУральского региона $/ / /$ Проблемы экологического мониторинга и моделирования экосистем, 2017. Т. 28(2). С. 86-99).

Peshkova G. A. 2001. Florogenetic Analysis of the Steppe Flora of the South Siberian Mountains. Nauka, Novosibirsk, 1-192 pp. [In Russian]. (Пешкова Г. А. Флорогенетический анализ степной флоры гор Южной Сибири. Новосибирск: Наука, 2001. 192 с.).

Petit R., Brewer S., Bordács S., Burg K., Cheddadi R., Coart E., Cottrell J., Csaikl U. M., van Dam B.C., Deans J. D., Espinel S., Fineschi S., Finkeldey R., Glaz I., Goicoechea P. G., Jensen J. S., König A. O., Lowe A. J., Madsen S. F., Mátyás G., Munro R.C., Popescu F., Slade D., Tabbener H., de Vries S. G. M., Ziegenhagen B., de Beaulieu J. L., Kremer A. 2002. Identification of refugia and post-glacial colonisation routes of European white oaks based on chloroplast DNA and fossil pollen evidence. Forest Ecology and Management 156: 49-74.

Petit R. J., Hu F. S., Dick C. W. 2008. Forests of the past: a window to future changes. Science 320: 1450-1452.

Pitulko V. V., Tikhonov A. N., Pavlova E. Y., Nikolskiy P. A., Kuper K. E., Polozov R. N. 2016. Early human presence in the Arctic: evidence from 45,000-year-old mammoth remains. Science 351: 260-263. 
Pokorný P., Chytrý M., Juricková L., Sádlo J., Novák J., Lozek V. 2015. Mid-Holocene bottleneck for Central European grasslands: did steppe survive the forest optimum in northern Bohemia, Czech Republic? The Holocene 25: 716-726. DOI: 10.1177/0959683614566218.

Popescu S.-M. 2006. Late Miocene and early Pliocene environments in the southwestern Black Sea region from high-resolution palynology of DSDP Site 380A (Leg 42B). Palaeogeography, Palaeoclimatology, Palaeoecology 238: 64-77.

Popov S. V., Shcherba I. G., Ilyina L. B., Nevesskaya L. A., Paramonova N. P., Khonkarian S. O., Magyar I. 2006. Late Miocene to Pliocene palaeogeography of the Paratethys and its relation to the Mediterranean. Palaeogeography, Palaeoclimatology, Palaeoecology 238: 91-106.

Popov S. V., Rögl S., Rozanov A. Y., Steininger F. F., Shcherba I. G., Kovac M., eds. 2004. Lithological-palaeogeographic maps of the Paratethys. Courier Forschungs-Institut Senckenberg 250: 1-46.

Popova S., Utescher T., Gromyko D., Bruch A. A., Mosbrugger V. 2012. Palaeoclimate evolution in Siberia and the Russian Far East from the Oligocene - evidence from fruit and see floras. Turkish Journal of Earth Sciences 21: 315-334. DOI: 10.3906/yer-1005-6.

Popova S., Utescher T., Gromyko D., Mosbrugger V., Herzog H., François L. 2013. Vegetation change in Siberia and the northeast of Russia during the Cenozoic cooling: a study based on diversity of plant functional types. Palaios 28: 418-432. DOI: 10.2110/palo.2012.p12-096r.

Popova S., Utescher T., Gromyko D. V., Bruch A. A., Henrot A.-J., Mosbrugger V. 2017. Cenozoic vegetation gradients in the mid- and higher latitudes of Central Eurasia and climatic implications. Palaeogeography, Palaeoclimatology, Palaeoecology 467: 69-82. DOI: 10.1016/j.palaeo.2016.09.016.

Poschlod P. 2015. Geschichte der Kulturlandschaft. Ulmer, Stuttgart, 321 pp.

Poschlod P., Baumann A., Karlik P. 2009. Origin and development of grasslands in Central Europe. In: Grasslands in Europe - of high nature value. Eds. P. Veen, R. Jefferson, J. de Smidt, J. vad der Straaten. KNNV Publishing, Zeist, 15-25 pp.

Pott R. 1992. Die Pflanzengesellschaften Deutschlands. Ulmer, Stuttgart, 427 pp.

Pott R. 1995. The origin of grassland species and grassland communities in Central Europe. Fitosociologia 29: 7-32.

Pott R. 1996. Die Entwicklungsgeschichte und Verbreitung xerothermer Vegetationseinheiten in Mitteleuropa unter dem Einfluss des Menschen. Tuexenia 16: 337-369.

Prasad V., Strömberg C. A. E., Alimohammadian H., Sahni A. 2005. Dinosaur coprolites and the early evolution of grasses and grazers. Science 310: 1177-1180.

Prasad V., Strömberg C. A. E., Leaché A. D., Samant B., Patnaik R., Tang L., Mohabey D. M., Ge S., Sahni A. 2011. Late Cretaceous origin of the rice tribe provides evidence for early diversification in Poaceae. Nature Communications 2: 480. DOI: 10.1038/ncomms1482.

Prentice I. C., Guiot J., Huntley B., Jolly D., Cheddadi R. 1996. Reconstructing biomes from palaeoecological data: a general method and its application to European pollen data at 0 and 6 ka. Climate Dynamics 12: 185-194.

Prescott G. W., Williams D. R., Balmford A., Green R. E., Manica A. 2012. Quantitative global analysis of the role of climate and people in explaining late Quaternary megafaunal extinctions. Proceedings of the Naional Academy of Sciences USA 109: 4527-4531. DOI: 10.1073/pnas.1113875109.

Prishchekov A. V., Müller D., Dubinin M., Baumann M., Rageloff V. C. 2013. Determinants of agricultural land abandonment in post-Soviet European Russia. Land Use Policy 30: 873-884. DOI: 10.1016/j.landusepol.2012.06.011.

Provan J., Bennett K. D. 2008. Phylogeographic insights into cryptic glacial refugia. Trends in Ecology and Evolution 23: 564-571.

Pyak A. I., Shaw S. C., Ebel A. L., Zverev A. A., Hodgson J. G., Wheller B. D., Gaston K. J., Morenko M. O., Revushkin A. S., Kotukhov Y. A., Oyunchimeg D. 2008. Endemic Plants of the Altai Mountain Country. Wild Guides, Hampshire, UK, 368 pp.

Quan C., Liu Y., Utescher T. 2012. Eocene monsoon prevalence over China: a paleobotanical perspective. Palaeogeography, Palaeoclimatology, Palaeoecology 365: 302-311. DOI: 10.1016/j.palaeo.2012.09.035.

Quan C., Liu Z., Utescher T., Jin J., Shu J., Li Y., Liu Y.-S. 2014. Revisiting the Palaeogene climate pattern of East Asia: A synthetic review. Earth-Science Reviews 139: 213-230. DOI: 10.1016/j.earscirev.2014.09.005.

Rabanus-Wallace M. T., Wooller M. J., Zazula G. D., Shute E., Jahren A. H., Kosintsev P., Burns J.A., Breen J., Llamas B., Cooper A. 2017. Megafaunal isotopes reveal role of increased moisture on rangeland during late Pleistocene extinctions. Nature Ecology \& Evolution 1: 0125. DOI: 10.1038/s41559-017-0125.

Rachkovskaya E. I., Bragina T. M. 2012. Steppes of Kazakhstan: diversity and present state. In: Eurasian steppes. Ecological problems and livelihoods in a changing world. Eds. M. J. A. Werger, M. A. van Staalduinen. Springer, Dordrecht, Heidelberg, New York, London, 103-148 pp.

Renner S. S. 2016. Available data point to a 4-km-high Tibetan Plateau by $40 \mathrm{Ma}$, but 100 molecular-clock papers have linked supposed recent uplift to young node ages. Journal of Biogeography 43: 1479-1487. DOI: 10.1111/ jbi.12755. 
Retallack G. J. 2001. Cenozoic expansion of grasslands and climatic cooling. Journal of Geology 109: 407-426.

Ripley E. A. 1992. Grassland climate. In: Natural Grasslands. Introduction and Western Hemisphere. Ed. R. T. Coupland. Elsevier, Amsterdam, 7-24 pp.

Roberts N. 2014. The Holocene: An Environmental History. Third edition, Wiley \& Sons, 376 pp.

Rögl F. 1998. Palaeogeographic considerations for Mediterranean and Paratethys seaways Oligocene to Miocene. Annalen Naturhistorisches Museum Wien 99A: 279-310.

Rögl F. 1999. Mediterranean and Paratethys, facts and hypotheses of an Oligocene to Miocene Paleogeography short overview. Geologica Carpathica 50: 339-349.

Rudaya N., Tarasov P., Dorofeyuk N., Solovieva N., Kalugin I., Andreev A., Daryin A., Diekmann B., Riedel F., Tserendash N., Wagner M. 2009. Holocene environments and climate in the Mongolian Altai reconstructed from the Hoton-Nur pollen and diatom records: a step towards better understanding climate dynamics in Central Asia. Quaternary Science Reviews 28: 540-554.

Rudaya N., Nazarova L., Nourgaliev D., Palagushkina O., Papin D., Frolova L. 2012. Mid-late Holocene environmental history of Kulunda, southern West Siberia: vegetation, climate and humans. Quaternary Science Reviews 48: 32-42. DOI: 10.1016/j.quascirev.2012.06.002.

Rudoy A. N. 2002. Glacier-dammed lakes and geological work of glacial superfloods in the Late Pleistocene, Southern Siberia, Altai Mountains. Quaternary International 87: 119-140.

Rull V. 2009. Microrefugia. Journal of Biogeography 36: 481-484.

Rutter N. W., Rokosh D., Evans M. W. E., Little E. C., Chlachula J., Velichko A. 2003. Correlation and interpretation of paleosols and loess across European Russia and Asia over the last interglacial-glacial cycle. Quaternary Research 60: 101-109.

Safranova I. N. 2005. The ecological classification of desert and steppe vegetation on the European Vegetation Map. In: Application and analysis of the Map of the Natural Vegetation of Europe. Eds. U. Bohn, C. Hettwer, G. Gollubpp. BfN-Skripten 156. BfN, Bundesamt für Naturschutz, Bonn, 113-121 pp.

Sage R. W. 2004. The evolution of $\mathrm{C}_{4}$ photosynthesis. New Phytologist 161: 341-370.

Saiko T. 2001. Environmental Crisis: Geographical Case Studies in Post-Socialist Eurasia. Addison-Wesely Longman Pearson, London, 320 pp.

Sandom C.J., Ejrnaes R., Hansen M. D. D, Svenning J.-C. 2014a. High herbivore density associated with vegetation diversity in interglacial ecosystems. Proceedings of the Naional Academy of Sciences USA 111: 4162-4167. DOI: 10.1073/pnas.1311014111.

Sandom C., Faurby S., Sandel B., Svenning J.-C. 2014b. Global late Quaternary megafauna extinctions linked to humans, not climate change. Proceedings of the Royal Society B 281: 20133254. DOI: 10.1098/rspb.2013.3254.

Sandve S. R., Fjellheim S. 2010. Did gene family expansions during the Eocene-Oligocene boundary climate cooling play a role in Pooideae adaptation to cool climates? Molecular Ecology 19: 2075-2088.

Sanjmyatav T. 2012. Mongolian nomads and climate change - a herder's view. In: Eurasian steppes. Ecological problems and livelihoods in a changing world. Eds. M. J. A. Werger, M. A. van Staalduinen. Springer, Dordrecht, Heidelberg, New York, London, 547-559 pp.

Schirrmeister L., Hubberten H.-W. 2014. Permafrost - Ein weit verbreitetes Klimaphänomen der Arktis und Subarktis. In: Warnsignal Klima: Die Polarregionen. Eds. J. L. Lozán, D. Notz, D. Piepenburg. Wissenschaftliche Auswertungen, Hamburg, 53-61 pp.

Schmithüsen J. 1968. Allgemeine Vegetationsgeographie. 3. Aufl. De Gruyter, Berlin, 463 pp.

Schmithüsen J. 1976. Atlas zur Biogeographie. Bibliographisches Institut, Mannheim, 88 pp.

Schroeder F.-G. 1998. Lehrbuch der Pflanzengeographie. Quelle \& Meyer, Wiesbaden, 457 pp.

Schultz J. 2008. Die Ökozonen der Erde. 4. Aufl. Ulmer, Stuttgart. English translation: The Ecozones of the World. 2nd edition. Springer, Berlin 2005, 368 pp.

Scotese C. R. 2000. Paleomap Project. URL: http://www.scotese.com/climate.htm (Accessed July 2016).

Seregin A. P., Anackov G., Friesen N. 2015. Molecular and morphological revision of the Allium saxatile group (Amaryllidaceae): geographical isolation as the driving force of underestimated speciation. Botanical Journal of the Linnean Society 178: 67-101. DOI: 10.1111/boj.12269.

Sharkhuu A., Sharkhuu N., Etzelmüller B., Flo Heggem E. S., Nelson F. E., Shiklomanov N. I., Goulden C. E., Brown J. 2007. Permafrost monitoring in the Hovsgol mountain region, Mongolia. Journal of Geophysical Research 112: F02S06

Sharkhuи N., Sharkhuи A. 2012. Effects of climate warming and vegetation cover on permafrost of Mongolia. In: Eurasian steppes. Ecological problems and livelihoods in a changing world. Eds. M. J. A. Werger, M. A. van Staalduinen. Springer, Dordrecht, Heidelberg, New York, London, 445-472 pp.

Shichi K., Kawamuro K., Takahara H., Hase Y., Maki T., Miyoshi N. 2007. Climate and vegetation changes around Lake Baikal during the last 350,000 years. Palaeogeography, Palaeoclimatology, Palaeoecology 248: 357375 . 
Shukla A., Mehrotra R., Spicer R. A., Spicer T. E. V., Kumar M. 2014. Cool equatorial terrestrial temperatures and the South Asian monsoon in the Early Eocene: evidence from the Gurha Mine, Rajastan, India. Palaeogeography, Palaeoclimatology, Palaeoecology 412: 187-198. DOI: 10.1016/j.palaeo.2014.08.004.

Smelansky I. E., Tishkov A. A. 2012. The steppe biome in Russia: ecosystem services, conservation status, and actual challenges. In: Eurasian steppes. Ecological problems and livelihoods in a changing world. Eds. M. J. A. Werger, M. A. van Staalduinen. Springer, Dordrecht, Heidelberg, New York, London, 45-101 pp.

Snyder $\boldsymbol{C}$. W. 2016. Evolution of global temperature over the past two million years. Nature 538: 226-228. DOI: 10.1038/nature19798.

Srivastava G., Spicer R. A., Spicer T. E. V., Yang J., Kumar M., Mehrotra R., Mehrotra N. 2012. Megaflora and palaeoclimate of a Late Oligocene tropical delta, Makum Coalfield, Assam: evidence for the early development of the South Asia Monsoon. Palaeogeography, Palaeoclimatology, Palaeoecology 342-343: 130-142. DOI: 10.1016/j. palaeo.2012.05.002.

Sochava V. B. 1979. Distribution of grasslands in the USSR. In: Ecology of Grasslands and Bamboolands in the World. Ed. M. Numata. VEB G. Fischer, Jena, 103-110 pp.

Stewart J. R., Lister A. M. 2001. Cryptic northern refugia and the origins of the modern biota. Trends in Ecology and Evolution 16: 608-613.

Stewart J. R., Lister A. M., Barnes I., Dalén L. 2010. Refugia revisited: individualistic responses of species in space and time. Proceedings of the Royal Society B 277: 661-671.

Strömberg $\boldsymbol{C}$. $\boldsymbol{A}$. $\boldsymbol{E}$. 2004. Using phytolith assemblages to reconstruct the origin and spread of grass-dominated habitats in the Great Plains during the late Eocene to early Miocene. Palaeogeography, Palaeoclimatology, Palaeoecology 207: 239-275.

Strömberg C. A. E. 2005. Decoupled taxonomic radiation and ecological expansion of open-habitat grasses in the Cenozoic of North America. Proceedings of the Naional Academy of Sciences USA 102: 11980-11984.

Strömberg C. A. E. 2011. Evolution of grasses and grassland ecosystems. Annual Review of Earth and Planetary Science 39: 517-544. DOI: 10.1146/annurev-earth-040809-152402.

Strömberg C. A. E., Dunn R. E., Madden R. H., Kohn M. J., Carlini A. A. 2013. Decoupling the spread of grasslands from the evolution of grazer-type herbivores in South America. Nature Communication 4: 1478. DOI: 10.1038/ ncomms2508.

Sun J., Zhang Z., Zhang L. 2009. New evidence on the age of the Taklimakan Desert. Geology 37: 159-162.

Sun J., We L., Wu W., Ni X., Bi S., Zhang Z., Liu W., Meng J. 2010. Late Oligocene-Miocene mid-latitude aridification and wind patterns in the Asian interior. Geology 38: 515-518. DOI: 10.1130/G30776.1.

Sun J., Ni X., Bi S., Wu W., Ye J., Meng J., Windley B. 2014. Synchronous turnover of flora, fauna, and climate at the Eocene-Oligocene Boundary in Asia. Scientific Reports 4: 7463. DOI: 10.1038/srep07463.

Sun J., Windley B. F. 2015. Onset of aridification by 34 Ma across the Eocene-Oligocene transition in Central Asia. Geology 43: 1015-1018. DOI: 10.1130/G37165.1.

Sun X., Wang P. 2005. How old is the Asian monsoon system? - Palaeobotanical records from China. Palaeogeography, Palaeoclimatology, Palaeoecology 222: 181-222.

Svendsen J. I., Alexanderson H., Astakhov V. I., Demidov I., Dowdeswell J. A., Funder S., Gataullin V., Henriksen M., Hjort C., Houmark-Nielsen M., Hubberten H. W., Ingólfsson O., Jakobsson M., Kjaer K. H., Larsen E., Lokrantz H., Pekka Lunkka J., Lysa A., Mangerud J., Míouvhko A., Murray A., Möller P., Niessen F., Nikolskaya O., Polyak L., Saarnisto M., Siegert C., Siegert M. J., Spielhagen R. F., Stein R. 2004. Late Quaternary ice sheet history of northern Eurasia. Quaternary Science Reviews 23: 1229-1271.

Svenning J.-C., Normand S., Kageyama M. 2008. Glacial refugia of temperate trees in Europe: insights from species distribution modelling. Journal of Ecology 96: 1117-1127.

Syabryaj S., Utescher T., Mochanoff S., Bruch A. A. 2007. Vegetation and palaeoclimates in the Miocene of Ukraine. Palaeogeography, Palaeoclimatology, Palaeoecology 253: 169-184.

Taberlet P., Fumagalli L., Wust-Saucy A.-G. 1998. Comparative phylogeography and postglacial colonization routes in Europe. Molecular Ecology 7: 453-464.

Takhtajan A. 1986. Floristic Regions of the World. Univ. California Press, Berkeley. Translated from Russian original, published 1978, $522 \mathrm{pp}$.

Tarasov P. E., Jolly D., Kaplan J. O. 1997. A continuous Late Glacial and Holocene record of vegetation changes in Kazakhstan. Palaeogeography, Palaeoclimatology, Palaeoecology 136: 281-292.

Tarasov P. E, Dorofeyuk N., Meteltseva E. 2000a. Holocene vegetation and climate changes in Hoton-Nur basin, northwest Mongolia. Boreas 29: 117-126.

Tarasov P. E., Volkova V. S., Webb T., Guiot J., Andreev A. A., Bezusko L. G., Bezusko T. V., Bykova G. V., Dorofeyuk N. I., Kvavadze E. V., Osipova I. M., Panova N. K., Sevastyanov D. V. 2000b. Last glacial maximum biomes reconstructed from pollen and plant macrofossil data from northern Eurasia. Journal of Biogeography 27: 609-620. 
Tarasov P. E., Williams J. W., Andreev A., Nakagawa T., Bezrukova E., Herzschuh U., Igarashi Y., Müller S., Werner K., Zheng Z. 2007. Satellite- and pollen-based quantitative woody cover reconstructions for northern Asia: verification and application to late-Quaternary pollen data. Earth and Planetary Letters 264: 284-298.

Tarasov P. E., Bezrukova E. V., Krivonogov S. K. 2009. Late Glacial and Holocene changes in vegetation cover and climate in southern Siberia derived from a $15 \mathrm{kyr}$ pollen record from Lake Kotokel. Climate of the Past 5: $285-295$.

Teeri J. A., Stowe L. G. 1976. Climatic patterns and the distribution of $\mathrm{C}_{4}$ grasses in North America. Oecologia 23: $1-12$

Ter Borg M., Vasiliev I., Stoica M., Knežeć S., Matenco L., Krijgsman W., Rundić L., Cloetingh S. 2013. The isolation of the Pannioan basin (Central Paratethys): new constraints from magnetostratigraphy and biostratigraphy. Global and Planetary Change 103: 99-118. DOI: 10.1016/j.gloplacha.2012.10.001.

Thomasson J. R. 1987. Fossil grasses: 1820-1986 and beyond. In: Grass Systematics and Evolution. Eds. T. R. Soderstrom, K. W. Hilu, C. S. Campbell, M. E. Barkworth. Smithsonian Inst. Press, Washington D.C., 159-167 pp.

Török P., Ambarh D., Kamp J., Wesche K., Dengler J. 2016. Step(pe) up! Raising the profile of the Palaearctic natural grasslands. Biodiversity and Conservation 25: 2187-2195. DOI: 10.1007/s10531-016-1187-6.

Tudryn A., Chalié F., Lavrushin Yu. A., Antipov M. P., Spiridonova E. A., Lavrushin V., Tucholka P., Leroy S. A. G. 2013. Late Quaternary Caspian Sea environment: Late Khzarian and Early Khvalynian transgressions from the lower reaches of the Volga River. Quaternary International 292: 193-204. DOI: 10.1016/j.quaint.2012.10.032.

Tzedakis P. C., Emerson B. C., Hewitt G. M. 2013. Cryptic or mystic? Glacial tree refugia in northern Europe. Trends in Ecology and Evolution 28: 696-704. DOI: 10.1016/j.tree.2013.09.001.

Utescher T., Mosbrugger $\boldsymbol{V}$. 2007. Eocene vegetation patterns reconstructed from plant diversity - a global perspective. Palaeogeography, Palaeoclimatology, Palaeoecology 247: 243-271.

Utescher T., Böhme M., Mosbrugger V. 2011. The Neogene of Eurasia: spatial gradients and temporal trends The second synthesis of NECLIME. Palaeogeography, Palaeoclimatology, Palaeoecology 304: 196-201. DOI: 10.1016/j.palaeo.2011.03.012.

Van Dam J. A. 2006. Geographic and temporal patterns in the late Neogene (12-3 Ma) aridification of Europe: the use of small mammals as paleoprecipitation proxies. Palaeogeography, Palaeoclimatology, Palaeoecology 238: $190-218$

Van Hinsbergen D. J. J., Boschman L. M. 2019. How high were these mountains? Science 363: 928-929. DOI: 10.1126/science.aaw7705.

Velichko A. A. 1999. General features of the landscape and climate of Northern Eurasia in the Cenozoic. In: Climate and Environment Changes during the last 65 Million Years; Cenozoic: from Paleocene to Holocene. Eds. A. A. Velichko, V. P. Nechaev. Chapter 10. GEOS, Moscow, 219-233 pp. [In Russian]. (Величко А. А. Общие особенности изменений ландшафтов и климата Северной Евразии в кайнозое // Изменение климата и ландшафтов за последние 65 миллионов лет (кайнозой: от палеоцена до голоцена. Под ред. А. А. Величко, В. П. Нечаева. М.: ГEOC, 1999. С. 219-233).

Velichko A. A., Curry B., Ehlers J. 2005. Main Quaternary chronostratigraphical units used in Siberia, EastEuropean Plain, West Europe and North America. In: Cenozoic Climatic and Environmental Changes in Russia. Eds. Jr. H. E. Wright, T. A. Blyakharchuk, A. A. Velichko, O. Borisova. Geological Society of America, Special Paper 382. Boulder, Colorado, P. xvii.

Velichko A. A., Isayeva L. L. 1992. Map of Landscape Types during maximum cooling of the last glaciation about 20.000 to 18.000 yr B.P. and explanatory notes to the map. In: Atlas of Paleoclimates and Paleoenvironments of the Northern Hemisphere, Late Pleistocene - Holocene. Eds. B. Frenzel, M. Pécsi, A. A. Velichko. Gustav-FischerVerlag, Budapest, Stuttgart, 59 and 125-126 pp.

Velichko A. A., Nechaev V. P., eds. 1999. Climate and Environment Changes during the last 65 Million Years; Cenozoic: from Paleocene to Holocene. GEOS, Moscow, 260 pp. [In Russian]. English-Language Edition. Eds. Jr. H. E. Wright, T. A. Blyakharchuk, A. A. Velichko, O. Borisova. 2005. Cenozoic Climatic and Environmental Changes in Russia. Geological Society of America, Special Paper 382. Boulder, Colorado.

Velichko A. A., Akhlestina E. F., Borisova O. K., Gribchenko Yu. I., Zhidovinov N. Yu., Zelikson E. M., Iosifova V. P., Klimanov V. A., Morozova T. V., Nechaev V. P., Pisareva V. V., Svetlitskaya T. V., Spasskaya I. I., Udartsev V. P., Faustova M. A., Shik S. M. 1999. East European plains. In: Climate and Environment Changes during the last 65 Million Years; Cenozoic: from Paleocene to Holocene. Eds. A. A. Velichko, V. P. Nechaev. Chapter 3. GEOS, Moscow, 43-83 pp. [In Russian]. (Величко А. А., Ахлестина Е. Ф., Борисова О. К., Грибченко Ю. Н., Жидовинов Н. Я., Зеликсон Э. М., Иосифова Ю. И., Климанов В. А., Морозова Т. Д., Нечаев В. П., Писарева В. В., Светлицкая Т. В., Спасская И. И., Ударцев В. П., Фаустова М. А., Шик С. М. Восточно-Европейская равнина // Изменение климата и ландшафтов за последние 65 миллионов лет (кайнозой: от палеоцена до голоцена. Под ред. А. А. Величко, В. П. Нечаева. М.: ГЕОС, 1999. С. 43-83).

Velichko A. A., Andreev A. A., Klimanov V. A. 1997. Climate and vegetation dynamics in the tundra and forest zone during the Late Glacial and Holocene. Quaternary International 41-42: 71-96. 
Velichko A. A., Catto N., Drenova A. N., Klimanov V. A., Kremenetski K. V., Nechaev V. P. 2002. Climate changes in East Europe and Siberia at the Late Glacial-Holocene transition. Quaternary International 91: 75-99.

Venter O., Fuller R. A., Segan D. B., Carwardine J., Brooks T., Butchart S. H., Di Marco M., Iwamura T., Joseph L., O'Grady D., Possingham H. P., Rondinini C., Smith R. J., Venter M., Watson J. E. 2014. Targeting global protected area expansion for imperilled biodiversity. PLoS Biology 12: e1001891. DOI: 10.1371/journal.pbio. 1001891.

Vicentini A., Barber J. C., Aliscioni S. S., Giussani L. M., Kellogg E. A. 2008. The age of the grasses and clusters of origins of $\mathrm{C}_{4}$ photosynthesis. Global Change Biology 14: 2963-2977.

Vigeland M. D., Spannagl M., Asp T., Paina C., Rudi H., Rognli O.-A., Fjellheim S., Sandve S. R. 2013. Evidence for adaptive evolution of low-temperature stress response genes in a Pooideae grass ancestor. New Phytologist 199: 1060-1068. DOI: 10.1111/nph.12337.

Von Wehrden H., Wesche K., Miehe G. 2009. Plant communities of the southern Mongolian Gobi. Phytocoenologia 39: 1-47.

Wagner V., Durka W., Hensen I. 2011. Increased genetic differentiation but no reduced genetic diversity in peripheral vs. central populations of a steppe grass. American Journal of Botany 98: 1173-1179. DOI: 10.3732/ajb.1000385.

Walker D. A., Bockheim J. G., Chapin III F. S., Eugster W., Nelson F. E., Ping C. L. 2001. Calcium-rich tundra, wildlife, and the "Mammoth Steppe". Quaternary Science Reviews 20: 149-163.

Walker M., Johnson S., Rasmussen S. O., Popp T., Steffensen J.-P., Gibbard P., Hoek W., Lowe J., Andrews J., Björck S., Cwynar L. C., Hughen K., Kershaw P., Kromer B., Litt T., Lowe D. J., Nakagawa T., Newnham R., Schwander J.2009. Formal definition and dating of the GSSP (Global Stratotype Section and Point) for the base of the Holocene using Greenland NGRIP ice core, and selected auxiliary records. Journal of Quaternary Science 24: 3-17.

Walker M. J. C., Berkelhammer M., Björck S., Cwynar L.C., Fisher D. A., Long A. J., Lowe J. J., Newnham R. M., Rasmussen S. O., Weiss H. 2012. Formal subdivision of the Holocene Series/epoch: a discussion paper by a Working Group of INTIMATE (Integration of ice-core, marine and terrestrial records) and the Subcommission on Quaternary Stratigraphy International Commission on Stratigraphy. Journal of Quaternary Science 27: 649-659. DOI: $10.1002 /$ jqs.2565.

Walter H. 1964. Die Vegetation der Erde in ökologischer Betrachtung. Band I. Die tropischen und subtropischen Zonen. VEB G. Fischer, Jena, 592 pp.

Walter H. 1968. Die Vegetation der Erde in öko-physiologischer Betrachtung. Band II. Die gemäßigten und arktischen Zonen. G. Fischer, Stuttgart, 1001 pp.

Walter H. 1973. Vegetation of the Earth in relation to climate and the eco-physiological conditions. Springer, New York, $237 \mathrm{pp}$.

Walter H. 1974. Die Vegetation Osteuropas, Nord- und Zentralasiens. G. Fischer, Stuttgart, 452 pp.

Walter H., Box E. 1976. Global classification of natural terrestrial ecosystems. Vegetatio 32: 75-81.

Walter H., Breckle S.-W. 1999. Vegetation und Klimazonen. 7. Aufl. Ulmer, Stuttgart. English translation: Breckle S.-W. 2002. Walter's Vegetation of the Earth. The Ecological Systems of the Geo-Biosphere. Springer, Heidelberg, $540 \mathrm{pp}$.

Walter H., Harnickell E., Mueller-Dombois D. 1975. Klimadiagramm-Karten der einzelnen Kontinente und die ökologische Klimagliederung der Erde. G. Fischer, Stuttgart, 36 pp.

Wang C., Zhao X., Liu Z., Lippert P. C., Graham S. A., Coe R. S., Haisheng Y., Zhu L., Liu S., Li Y. 2008. Constraints on the early uplift history of the Tibetan Plateau. Proceedings of the National Academy of Sciences USA 105: 4987-4992.

Warmuth V., Eriksson A., Bower M. A. Cañon J., Cothran G., Distl O., Glowatzki-Mullis M.-L., Hunt H., Luís C., do Mar Oom M., Yupanqui I. T., Ząbek T., Manica A. 2011. European domestic horses originated in two Holocene refugia. PLoS ONE 6: e18194. DOI: 10.1371/journal.pone.0018194.

Warmuth V., Eriksson A., Bower M. A., Barker G., Barrett E., Hanks B. K., Li S., Lomitashvili D., OchirGoryaeva M., Sizonov G. V., Soyonov V., Manica A. 2012. Reconstructing the origin and spread of horse domestication in the Eurasian steppe. Proceedings of the National Academy of Sciences USA 109: 8202-8206. DOI: 10.1073/ pnas.1111122109.

Weber H. E., Moravec J., Theurillat J. P. 2000. International Code of phytosociological nomenclature. 3rd edition. Journal Vegetation Science 11: 739-768.

Wendelberger G. 1956. Die Waldsteppen des pannonischen Raumes. Versuch einer Deutung. Veröffentlichungen Geobotanischen Instituts, Stiftung Rübel, Zürich, 35: 77-113.

Werger M. J. A., van Staalduinen M. A., eds. 2012. Eurasian steppes. Ecological problems and livelihoods in a changing world. Springer, Dordrecht, Heidelberg, New York, London, 568 pp.

Wesche K., Ambarh D., Kamp J., Török P., Treiber J., Dengler J. 2016. The Palaearctic steppe biome: a new synthesis. Biodiversity and Conservation 25: 2197-2231. DOI: 10.1007/s10531-016-1214-7.

Wesche K., Treiber J. 2012. Abiotic and biotic determinants of steppe productivity and performance - a view from Central Asia. In: Eurasian steppes. Ecological problems and livelihoods in a changing world. Eds. M. J. A. Werger, M. A. van Staalduinen. Springer, Dordrecht, Heidelberg, New York, London, 3-43 pp. 
White R., Murray S., Rohweder M. 2000. Pilot analysis of global ecosystems: grassland ecosystems technical report. World Resource Institute, Washington, DC, 100 pp.

Wilhelmy H. 1950. Das Alter der Schwarzerden und der Steppen Mittel- und Osteuropas. Erkunde 4: 5-34.

Willerslev E., Davison J., Moora M., Zobel M., Coissac E., Edwards M. E., Lorenzen E. D., Vestergård M., Gussarova G., Haile J., Craine J., Gielly L., Boessenkool S., Epp L. S., Pearman P. B., Cheddadi R., Murray D., Bråthen K. A., Yoccoz N., Binney H., Cruaud C., Wincker P., Goslar T., Alsos I. G., Bellemain E., Brysting A. K., Elven R., Sønstebo J. H., Murton J., Sher A., Rasmussen M., Ronn R., Mourier T., Cooper A., Austin J., Möller P., Froese D., Zazula G., Pompanon F., Rioux D., Niderkorn V., Tikhonov A., Savvinov G., Roberts R. G., MacPhee R. D., Gilbert M. T., Kjaer K. H., Orlando L., Brochmann C., Taberlet P. 2014. Fifty thousand years of arctic vegetation and megafaunal diet. Nature 506: 47-51. DOI: 10.1038/nature12921.

Willis K. J. 1996. Where did all the flowers go? The fate of temperate European flora during glacial periods. Endeavor 20: 110-114.

Willis K. J., Whittaker R. J. 2000. The refugial debate. Science 287: 1406-1407.

Willis K. J., Rudner E., Sümegi P. 2000. The full-glacial forests of central and southeastern Europe. Quaternary Research 53: 203-213.

Willis K. J., van Andel T. H. 2004. Trees or no trees? The environments of central and eastern Europe during the Last Glaciation. Quaternary Science Reviews 23: 2369-2387.

Willner W., Kuzemko A., Dengler J., Chytry M., Bauer N., Becker T., Biţa-Nicolae C., Botta-Dukat Z., Carni A., Csiky J., Igic R., Kacki Z., Korotchenko I., Kropf M., Krstivojevic-Cuk M., Krstonosic D., Redei T., Ruprecht E., Schratt-Ehrendorfer L., Semenishchenkov Y., Stancic Z., Vashenyak Y., Vynokurov D. 2016. A higher-level classification of the Pannonian and western Pontic steppe grasslands Central and Eastern Europe. Applied Vegetation Science 20(1): 143-158. DOI: 10.1111/avsc. 12265.

Wolfe J. A. 1985. Distribution of major vegetational types during the Tertiary. In: The carbon cycle and atmospheric $\mathrm{CO}_{2}$. E. T. Sundquist, W. S. Broecker. American Geophys. Union. Washington D.C., 357-375 pp.

Wright Jr. H. E., Blyakharchuk T. A., Velichko A. A., Borisova O., eds., 2005. Cenozoic Climatic and Environmental Changes in Russia. The Geological Society of America, Special Paper 382. Boulder, Colorado. English Edition of Velichko A. A., Nechaev V. P., eds. 1999. Climate and Environment Changes during the last 65 Million Years; Cenozoic: from Paleocene to Holocene. GEOS, Moscow, 260 pp. [In Russian]. (Изменение климата и ландиафтов за последние 65 миллионов лет (кайнозой: от палеоцена до голоцена. Под ред. А. А. Величко, В. П. Нечаева. M.: ГEOC, 1999. 260 c.).

Wróblewska A. 2008. From the center to the margins of geographical range: molecular history of steppe plant Iris aphylla L. in Europe. Plant Systematics Evolution 272: 49-65.

Yang X., Scuderi L., Paillou P., Liu Z., Li H., Ren X. 2011. Quaternary environmental changes in the drylands of China - A critical review. Quaternary Science Reviews 30: 3219-3233. DOI: 10.1016/j.quascirev.2011.08.009.

Yang X., Rost K. T., Lehmkuhl F., Zhenda Z., Dodson J. 2004. The evolution of dry lands in northern China and in the Republic of Mongolia since the Last Glacial Maximum. Quaternary International 118-119: 69-85.

Yanina T., Sorokin V., Bezrodnykh Yu., Romanyuk B. 2018. Late Pleistocene climatic events reflected in the Caspian Sea geological history based on drilling data. Quaternary International 465, Part A: 130-141. DOI: 10.1016/j. quaint.2017.08.003.

Yu K. 2016. Paleoclimate implications from late Quaternary terrestrial archives in the Gobi Desert: examples from the Ejina Basin and Orog Nuur Basin. PhD Thesis, Rheinisch-Westfälische Technische Hochschule Aachen.

Yurtsev B. A. 1974. Steppe communities of Chukotka tundra and the Pleistocene "Tundra-Steppe". Bot. Zhurn. (Moscow \& Leningrad) 59(4): 484-501 [In Russian]. (Юрцев Б. А. Степные сообщества Чукотской тундры и плейстоценовая «тундростепь» // Бот. журн., 1974. Т. 59, № 4. С. 484-501).

Yurtsev B. A. 1978. Some questions of typology of steppe phytocoenoses in the northeastern Asia. Bot. Zhurn. (Moscow \& Leningrad) 63(11): 1566-1578 [In Russian]. (Юрцев Б. А. Некоторые вопросы типологии степных сообществ Северо-Восточной Азии // Бот. журн., 1978. Т. 63, № 11. С. 1566-1578).

Yurtsev B. A. 1981. Relic Steppe Complexes of Northeastern Asia. Nauka Press, Novosibirsk, 168 pp. [In Russian]. (Юрцев Б. А. Реликтовые степные комплексы Северо-Восточной Азии. Новосибирск: Наука, 1981. 168 с.).

Yurtsev B. A. 1982. Relics of the xerophyte vegetation of Beringia in northeastern Asia. In: Paleoecology of Beringia. Eds. D. M. Hopkins, Jr. J. V. Matthews, C. E. Schweger, S. Young. Acad. Press, New York, London, $157-177$ pp.

Yurtsev B. A. 1986. Megaberingia and the cryo-xeric stages of the history of its vegetation cover. Komarovskiye Chteniya (Vladivostok) 33: 3-53 [In Russian]. (Юрцев Б. А. Мегаберингия и криоксеротические этапы истории ее растительного покрова // Комаровские чтения (Владивосток), 1986. Т. 33. С. 3-53).

Yurtsev B. A. 2001. The Pleistocene "Tundra-Steppe" and the productivity paradox: the landscape approach. Quaternary Science Reviews 20: 165-174.

Zachos J. C., Pagani M., Sloan L., Thomas E., Billups K. 2001. Trends, rhythms, and aberrations in global climate 65 Ma to present. Science 292: 686-693. 
Zachos J. C., Dickens G. R., Zeebe R. E. 2008. An early Cenozoic perspective on greenhouse warming and carbon-cycle dynamics. Nature 451: 279-283.

Zakh A., Ryabogina N. E., Chlachula J. 2010. Climate and environmental dynamics of the mid- to late Holocene settlement in the Tobol - Ishim forest-steppe region, west Siberia. Quaternary International 220: 95-101. DOI: 10.1016/j.quaint.2009.09.010.

Zhang Z., Flatoy F., Wang H., Bethke I., Bentsen M., Guo Z. 2012. Early Eocene Asian climate dominated by desert and steppe with limited monsoons. Journal of Asian Earth Sciences 44: 24-35. DOI: 10.1016/j.jseaes.2011.05.013.

Zhilich S., Rudaya N., Krivonogov S., Nazarova L., Pozdnyakov D. 2017. Environmental dynamics of the Baraba forest-steppe (Siberia) over the last 8000 years and their impact on the types of economic life of the population. Quaternary Science Reviews 163: 152-161. DOI: 10.1016/j.quascirev.2017.03.022.

Zimov S. A., Zimov N. S., Tikhonov A. N., Chapin III F. S. 2012. Mammoth steppe: a high-productivity phenomenon. Quaternary Science Reviews 57: 26-45. DOI: 10.1016/j.quascirev.2012.10.005.

Zonn I. S. 1995. Desertification in Russia: problems and solutions (an example in the Republic of Kalmykia-Kalm Tangch). Environmental Monitoring and Assessment 37: 347-363. 